Report of Investigations No. 87

\title{
Catahoula Formation of the Texas Coastal Plain: Depositional Systems, Composition, Structural Development, Ground-Water Flow History, and Uranium Distribution
}

William E. Galloway

Assisted by T.D. Murphy, R.C. Belcher, B.D. Johnson, and Stanley Sutton

Project funded October 1975 - October 1976

by U.S. Energy Research and Development Administration

Contract No. E (O5-1)-1660

Bureau of Economic Geology

The University of Texas at Austin

W. L. Fisher, Director

1977 



\section{Catahoula Formation of the Texas Coastal Plain: Depositional Systems, Composition, Structural Development, Ground-Water Flow History, and Uranium Distribution}

William E. Galloway

Assisted by T.D. Murphy, R.C. Belcher, B.D. Johnson, and Stanley Sutton

Project funded October 1975 - October 1976

by U.S. Energy Research and Development Administration

Contract No. E (O5-1) TwG Goort mas prepared as an account of work sponsored by the United States Government. Neither the and States mer the United States Eneroy Resaarch and Develrpment Administration. $n \cdot T=7 y$ of fhrir am-

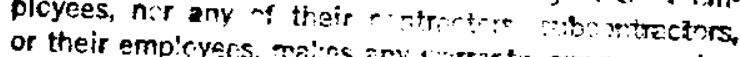

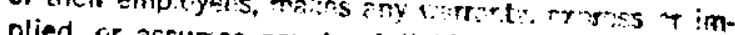

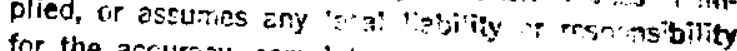

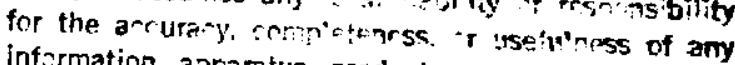
information, anmontus, prewt orress jisplensed.

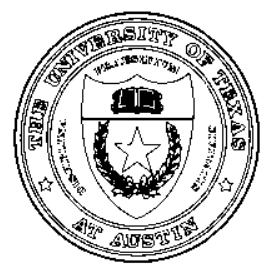
or represents that its use would not infringe privatety
owned rights.

Bureau of Economic Geology

The University of Texas at Austin

W. L. Fisher, Director

1977 



\section{CONTENTS}

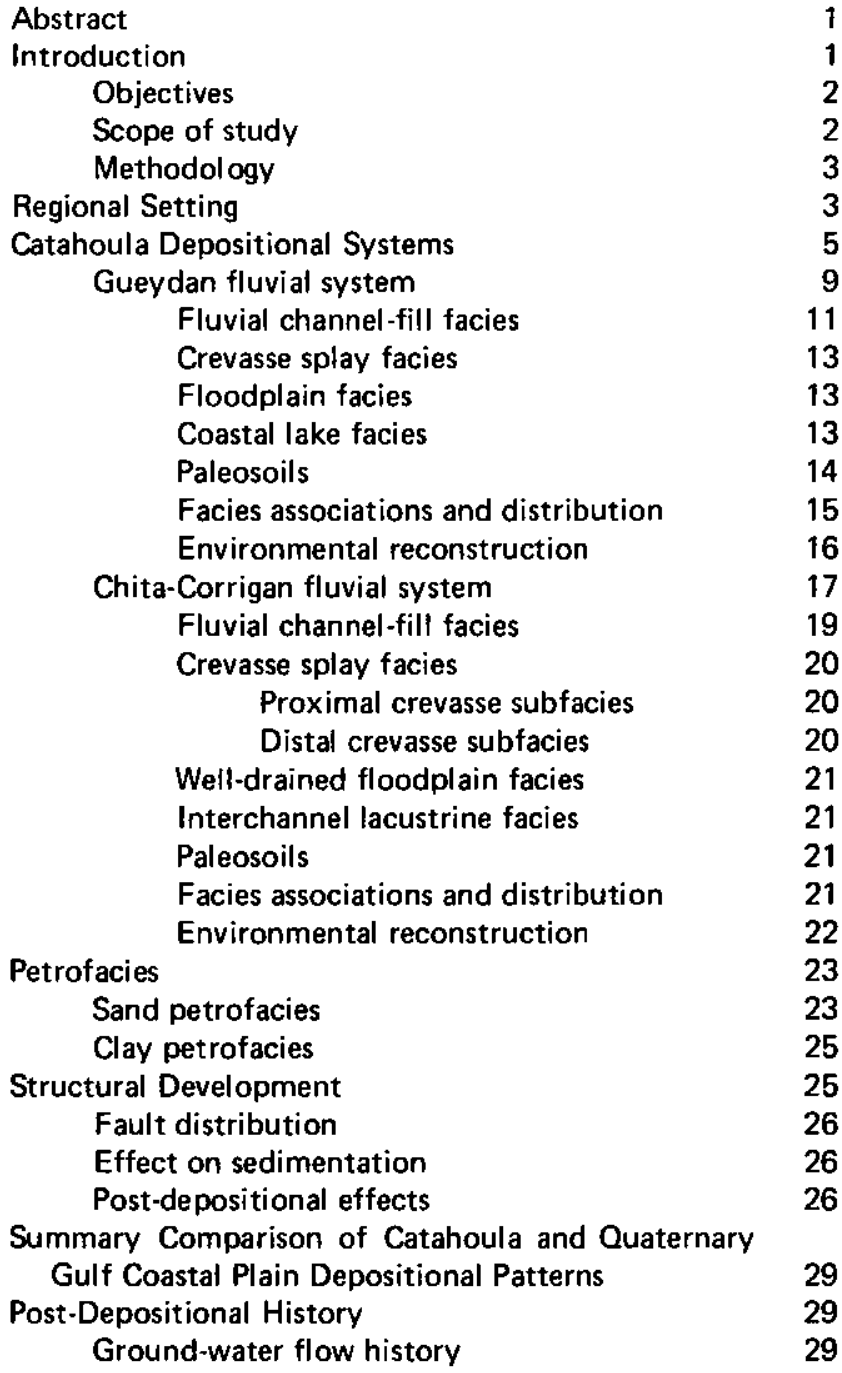

1

1

2

2

3

3 3
Factors determining ground-water flux Terrigenous coastal plain flow system Modern Catahoula flow system Historical development of the Catahoula flow system Syndepositional phase Post-depositional phase Burial phase Exhumation phase

Post-depositional diagenetic features Sand and sandstone

Volcanic ash

Organic material

Source, Distribution, and Migration of Uranium in Catahoula Fluvial Systems

Source of uranium

Background uranium content

Characteristics and distribution of uranium enrichment

Geology of Catahoula ore bodies

Summary of Catahoula uranium cycle

Regional Exploration Criteria

Comparative exploration potential of Gueydan and Chita-Corrigan fluvial systems

Exploration potential within the Chita-Corrigan and Gueydan fluvial systems

Gueydan fluvial system

Chita-Corrigan fluvial system

Conclusions

Speculations

Acknowledgements

References

Appendix 1. Well logs used in cross sections D-D' and $0-O^{\prime}$ (figures 4 and 5 )

Appendix 2. Localities illustrated in facies cross sections (figures 10 and 12 )
30

31

32

35

35

35

35

35

36

37

37

38

38

38

39

42

44

45

47

48

48

49

49

51

52

53

53

58

59

\section{FIGURES}

1. Location index map showing general Catahoula outcrop belt and grid of strikeand-dip sections used to establish a regional correlation framework

2. Relation of Catahoula to principal surface and subsurface units of the Rio Grande embayment and Houston embayment

3. Relation of the Catahoula Formation, as defined in this study, to principal surface and shallow subsurface units commonly used in the literature and as delineated on map sheets of the Geologic Atlas of Texas

4. Representative dip cross section D.D' illustrating the correlation of the Catahoula in the Rio Grande embayment
5. Representative dip cross section $0-\mathrm{O}^{\prime}$ illustrating the correlation of the Catahoula in the Houston embayment facies of the Catahoula

of the Catahoula showing the vertical distribution of the principal component facies of each depositional system

8. Internal structures of Gueydan fluvial bedload channel fill exposed by uranium mining in southwest Karnes County

59 9. Section of basal Gueydan crevasse splay facies overlying bedded deposits of the coastal lake facies exposed by mining in northern Live Oak County
26 Depositional systems and principal genetic

7. Regional shallow strike cross section (U-S) 
10. Composite cross section of a Gueydan fluvial channel complex illustrating lateral relationships of the various facies discussed in text

11. Schematic reconstruction of Gueydan depositional environments

12. Composite cross section of a Chita-Corrigan fluvial channel complex illustrating lateral relationships of facies discussed in text

13. Schematic reconstruction of Chita-Corrigan depositional environments

14. Petrofacies summary of the Catahoula Formation

15. Areas of Oligocene volcanism and probabie high-altitude wind patterns

16. Summary history of a growth fault zone in the lower Tertiary Gulf coast basin

17. Isolith map of middle Gueydan sand showing effect of associated faults on geometry and trend of fluvial sand bodies

18. Cross sections showing abrupt changes in stratigraphic position of sand bodies across faults

19. Comparison of Catahoula (Oligocene) and Quaternary coastal plain geomorphology, depositional patterns, and climatic zonation

20. Simplified regional pattern of ground-water flow in a terrigenous coastal plain setting

21. Distribution of fresh to slightly saline water in the Catahoula

22. Vertical displacement of the base of freshwater-bearing Catahoula sands in proximity to faulting

15

18 coastal plain aquifer system

24. Carbonaceous $\log$ and silicified log collected from the same road metal pit

25. Average bismuth and bismuth-thallium gamma radiation recorded by a regional gamma-radiation spectral survey across the Catahoula outcrop belt

26. Average and median uranium content of 103 samples grouped by grain size and inferred depositional environment

27. Distribution of known uranium ore deposits and areas of abundant anomalies within the structural and stratigraphic framework of the Gueydan fluvial system

28. Distribution of uranium ore deposits relative to the distribution of underlying petroleum accumulations

29. Features of a typical uranium mineralization front in area 2

30. Diagrammatic representation of the two principal phases of uranium cycle interpreted for Catahoula fluvial systems

31. Summary map showing relative exploration potential within the Gueydan and ChitaCorrigan fluvial systems based on integration of stratigraphic, facies, and structural data

\section{PLATES}

I. Catahoula net sand isopach

II. Net sand isopach, upper and lower Catahoula intervals
In pocket

In pocket
III. Number of sands $\geqslant 30 \mathrm{ft}$ in thickness

IV. Distribution of major faults
In pocket In pocket

TABLES

1. Stratigraphic characteristics of principal stream channel types
2. Uranium content of Catahoula samples determined by fluorometric analysis 


\title{
CATAHOULA FORMATION OF THE TEXAS COASTAL PLAIN: DEPOSITIONAL SYSTEMS, COMPOSITION, STRUCTURAL DEVELOPMENT, GROUND-WATER FLOW HISTORY, AND URANIUM DISTRIBUTION
}

\author{
William E. Galloway
}

\begin{abstract}
The Catahoula Formation of the Texas Gulf Coastal Plain consists of two depositional systems-the Gueydan bedload fluvial system of the Rio Grande embayment and the Chita-Corrigan mixed load fluvial system of the Houston embayment. Both systems contain distinctive fluvial channel-fill, crevasse splay, floodplain, and lacustrine facies, which tend to persist vertically through the section. The paleoclimate varied from subarid in the Gueydan system to humid in northeastern parts of the Chita-Corrigan system. Gueydan sands are dominated by plagioclase feldspar and volcanic rock fragments reflecting a western source; in contrast, Chita-Corrigan sands are quartzose and were primarily reworked from mixed sedimentary terranes. Clay composition reflects alteration to montmorillonite and kaolinite of large volumes of volcanic ash deposited in both systems in response to pedogenesis and shallow burial diagenesis.
\end{abstract}

ABSTRACT
Growth faults initiated by early Tertiary deltaic progradation extend up into the Catahoula and profoundly influence trends of fluvial sand units and post-depositional ground-water flow. Consequently, fault zones may localize uranium mineralization, but faulting is not necessary for development of commercial deposits.

Diagenetic features, distribution of trace uranium in fine-grained tuffaceous facies, and reconstructed ground- water flow history in the Catahoula provide the basis for interpretation of a terrigenous coastal plain uranium cycle.

1. Uranium was leached from volcanic ash soon after deposition by pedogenic processes and moved into shallow ground-water circulation cells.

2. Oxidizing uraniumenriched waters entered semiconfined aquifer sands in areas of regional recharge.

3. Geometry of the flow system was determined by the three-dimensional facies and structural framework of the aquifer system.

4. Uranium was concentrated by aqueous geochemical gradients as discrete mineralization fronts that were closely associated with iron oxidation fronts. Uranium was preferentially deposited where facies changes or faulting induced cross-stratal flow from permeable fluvial channel facies into interbedded or less permeable overbank facies.

5. Post-mineralization decrease of regional and local ground-water flux has resulted in reequilibration of large parts of the aquifer with the regionally reducing subsurface environment.

The inferred uranium cycle provides criteria that can be used to compare the uranium potential of the Gueydan and Chita-Corrigan fluvial systems and to determine the possible distribution and nature of mineralization within each depositional system. These criteria apply similarly to other potential coastal plain uranium host systems.

\section{INTRODUCTION}

Following the discovery of uranium in the South Texas Coastal Plain in 1954, significant ore reserves have been discovered in host units ranging in age from Late Eocene to Pliocene. Exploitation of the resource began with mining of Jackson (Eocene) deposits in Karnes County and later expanded to Oakville (Miocene) deposits in Live Oak County. Concomittant with mining operations, which continued with only temporary interruption from 1961 until the present, geologic study of coastal plain deposits produced a small, but significant body of literature describing the geology of the deposits and suggesting criteria for their formation and further exploration (Eargle and Weeks, 1961, 1968; Weeks and Eargle, 1963; Fisher and others, 1970; Klohn and Pickens, 1970; Eargle, Hinds, and Weeks, 1971; McKnight, 1972; Bunker and MacKallor, 1973; and Eargle, Dickinson, and Davis, 1975). Although the potential of the Catahoula Formation as a source of uranium was recognized, mining bypassed this Oligocene unit and consequently few data on Catahoula deposits have been published. With the advent of in situ leach mining technology and the expansion of surface mining operations, the Catahoula is assuming its role as a major producing host, and information on the distribution and nature of mineralization is becoming available. 


\section{OBJECTIVES}

This report describes the physical geology of the Catahoula Formation-its genetic stratigraphy, structure, mineralogical composition, and post-depositional historyand discusses the known distribution of uranium within the context of these geological parameters. Emphasis is on definition of primary physical and historical factors affecting the mobilization, transport, and concentration of uranium in the Catahoula Formation.

A number of geological parameters have been proposed as ore guides (Grutt, 1971; Fischer, 1974). Application of the general criteria summarized by these authors indicates that the entire Catahoula Formation of the Texas Coastal Plain is a potential uranium host. Obviously, greater discrimination is required; exploration history has shown that all parts of the Catahoula are not equally mineralized. Additional ore controls that have been specifically suggested for coastal plain deposits include: (1) faults in the ore-bearing section (Klohn and Pickins, 1970; Eargle and Weeks, 1973); (2) vertically migrating hydrocarbons or hydrogen sulfide (Eargle and Weeks, 1961); (3) thick sands which interfinger with surrounding mudrocks (Klohn and Pickins, 1970; Fisher and others, 1970); and (4) post-depositional, arid climate, soil-forming processes (Weeks and Eargle, 1963). The applicability of each of these proposed controls to Catahoula mineralization was tested, first by determining regional geographic coincidence and secondly, where possible, by defining the process-response relation involved. Results reflect the data generated in this study, as well as the expanding knowledge of other coastal plain formations to which similar criteria have also been applied.

Geologic factors believed to be significant in Catahoula mineralization have been mapped or compiled and are included in the report. These data provide a regional overview of major depositional, structural, and mineralogical trends within an internally consistent, genetic stratigraphic framework.

Application of relationships developed in this study to the regional geologic framework results in an evaluation of underexplored portions of the Catahoula. Rather than a ranking or arbitrary favorability index, geographic areas are discussed in terms of potential size, abundance, and downdip extent of ore bodies based on comparisons of ore-host relationships recognized in well-explored portions of the Catahoula, in similar depositional systems of the Coastal Plain, and in other uraniferous basins. Interpretation is directed not at predicting the pounds of uranium likely to be contained in a specific area, but at determining the nature of deposits that might be found (such as multiple small ore bodies in the 1 million pound size class vs. several large ore bodies in the 10 to 20 million pound class). Additional geological features associated with mineralization, such as the position, complexity, or state of preservation of alteration fronts, are also controlled by the host depositional system, and some general relationships are proposed.

Future exploration in the Catahoula will test the validity of assumptions upon which the area evaluations are based. Undoubtedly, the addition of new data will modify or refine interpretations made here. Consequently, this report is presented as a working document. Additional reports incorporating the data, as well as more detailed analysis of geochemical aspects of uranium concentration in coastal plain units will follow.

\section{SCOPE OF STUDY}

This study includes the outcrop and subsurface distribution of the Catahoula Formation from the Rio Grande on the south to the Sabine River on the east (fig. 1). The area covers approximately 19,000 square miles $(49,000$ square $\mathrm{km})$. The downdip limit of subsurface analysis was placed where dominantly coastal plain fluvial deposits of the Catahoula grade into equivalent deltaic and barrier-strandplain systems of the Frio-Anahuac Formations. Over most of the coastai plain, this transition occurs approximately along the line at which the top of the Catahoula dips $2,000 \mathrm{ft}(600 \mathrm{~m})$ below the surface.

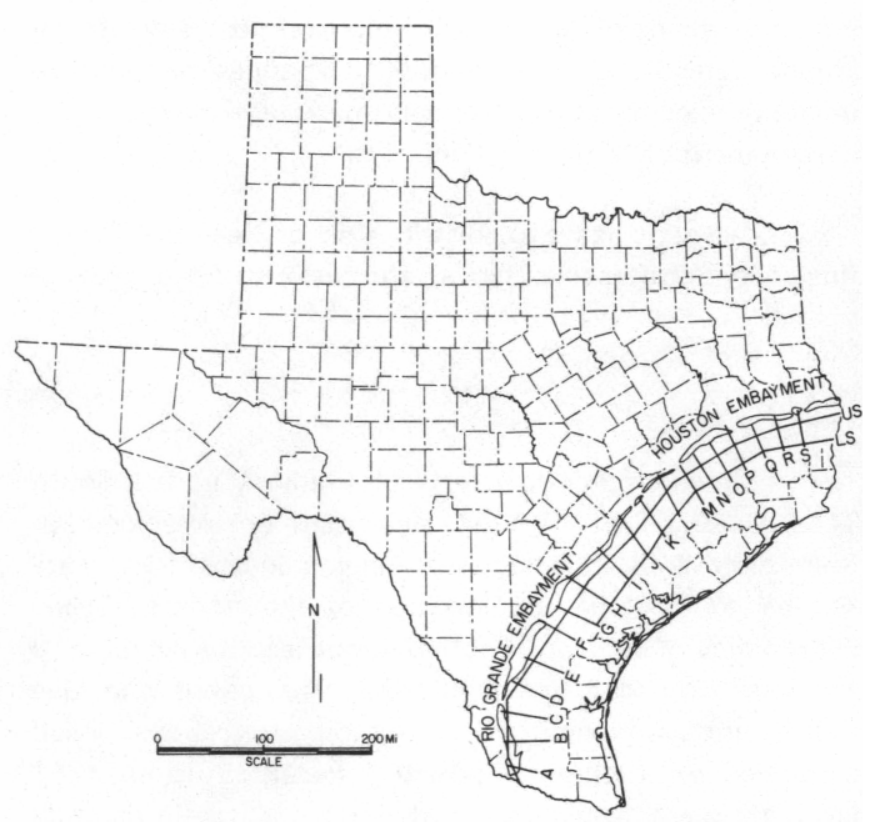

Figure 1. Location index map showing general Catahoula outcrop belt and grid of strike-and-dip sections used to establish a regional correlation framework. 
Significant expansion of the Catahoula-Frio section across a belt of growth faults also occurs at or just downdip of this transition. The equivalent subsurface Frio Formation is described in a series of reports by Bebout and others (1975a, b, 1976). These reports, combined with this study, provide an overview of the entire Middle to Late Oligocene sediment dispersal system.

This report concentrates on the genetic stratigraphy, structural configuration, composition, and regional groundwater flow dynamics of the Catahoula. Mineralogical and geochemical analyses have been of a reconnaissance nature.

\section{METHODOLOGY}

The primary data base for the subsurface study consisted of approximately 1100 petroleum and water-well electrical logs. Well samples were rarely available. The outcrop belt, which has been mapped for the Geologic Atlas of Texas (V.E. Barnes, project director), was compiled from the Beaumont Sheet (1968), Palestine Sheet (1968), Austin Sheet (1974), Seguin Sheet (1974), BeevilleBay City Sheet (1975), Crystal City-Eagle Pass Sheet (1976), Laredo Sheet (1976), and McAllen-Brownsville Sheet (1976). Samples, cores, uranium drill logs, and cross sections loaned by various companies provided additional control in local areas. Commercially available structure maps were used for analysis of fault distribution in the Catahoula Formation.

Surface and subsurface data were combined to construct a series of stratigraphic sections and maps that form the basis for definition, interpretation, and evaluation of Catahoula depositional systems, their component facies, and structural configuration. Initially, 19 dip-oriented cross sections, carefully projected updip to the outcrop and downdip to laterally correlative units within the marine Frio section, were tied by two strike-oriented cross sections to provide an internally consistent correlation framework (fig. 1). Although several locally useful horizons or log markers aided correlation, major changes in depositional style along strike necessitated careful integration of outcrop, shallow subsurface, and deep subsurface data. Correlations were carried northeastward from South Texas to insure that the known uranium-bearing portion of the stratigraphic section would be included for study in East Texas. The Catahoula section could not be regionally subdivided in South Texas; however, upper and lower intervals could be separated in eastern Texas.

Well logs were correlated into the cross-section grid and a series of lithofacies maps were compiled. Included are net sandstone isolith maps for the entire Catahoula (plate I) and for the upper and lower Catahoula of the upper Coastal Plain (plate II) and a map showing a number of thick sand bodies for the entire Catahoula (plate III). Sand geometry and distribution patterns displayed on these maps provided the basis for recognition of the depositional systems and their component facies.

Structural maps were compiled at the same scale to show the trend and distribution of principal fault zones that might have influenced Catahoula deposition (plate IV). Combination of lithofacies maps with log response and surface and subsurface lithologic data resulted in a number of derivative maps and figures, which illustrate interrelationships between geologic parameters and the formation and distribution of uranium mineralization.

\section{REGIONAL SETTING}

The Catahoula was deposited on the subsiding margin of the Gulf coast sedimentary basin. At the outcrop, thickness of the formation ranges from approximately 200 ft $(60 \mathrm{~m})$ to $1,000 \mathrm{ft}(300 \mathrm{~m})$. Beds dip regionally basinward at less than one degree, though local reversal may occur along fault zones. The Catahoula, as is typical of other Tertiary sequences, thickens gradually basinward until reaching one or more belts of contemporaneous faults. Interval thickness expands dramatically across these faults (Bebout and others, 1975a, b) and coincident with a major change from fluvial coastal plain facies to deltaic and marginal marine facies.

Although localized syndepositional structural features such as the growth fault belts have a more dramatic effect on sedimentary patterns, three broad, regional structural elements strongly influenced Catahoula-Frio deposition
(Hardin, 1962). The Rio Grande and Houston embayments (fig. 1 ) formed broad depocenters separated by the San Marcos arch, which extends southeast from central Gonzales County into Victoria County. These passive structural features have a long history. The embayments are areas of general subsidence; the arch forms a more stable gulfward-plunging platform. Concentration of sand in the embayments is obvious on the total Catahoula sand isolith map (plate I).

The embayments are depositional subbasins in which internal stratigraphy of the Catahoula-Frio and bounding relationships with other units differ considerably. These contrasting relationships are summarized diagrammatically in figure 2. The updip part of the Catahoula Formation was deposited on a progradational platform established by Yegua and Jackson barrier-strandplain and deltaic systems 

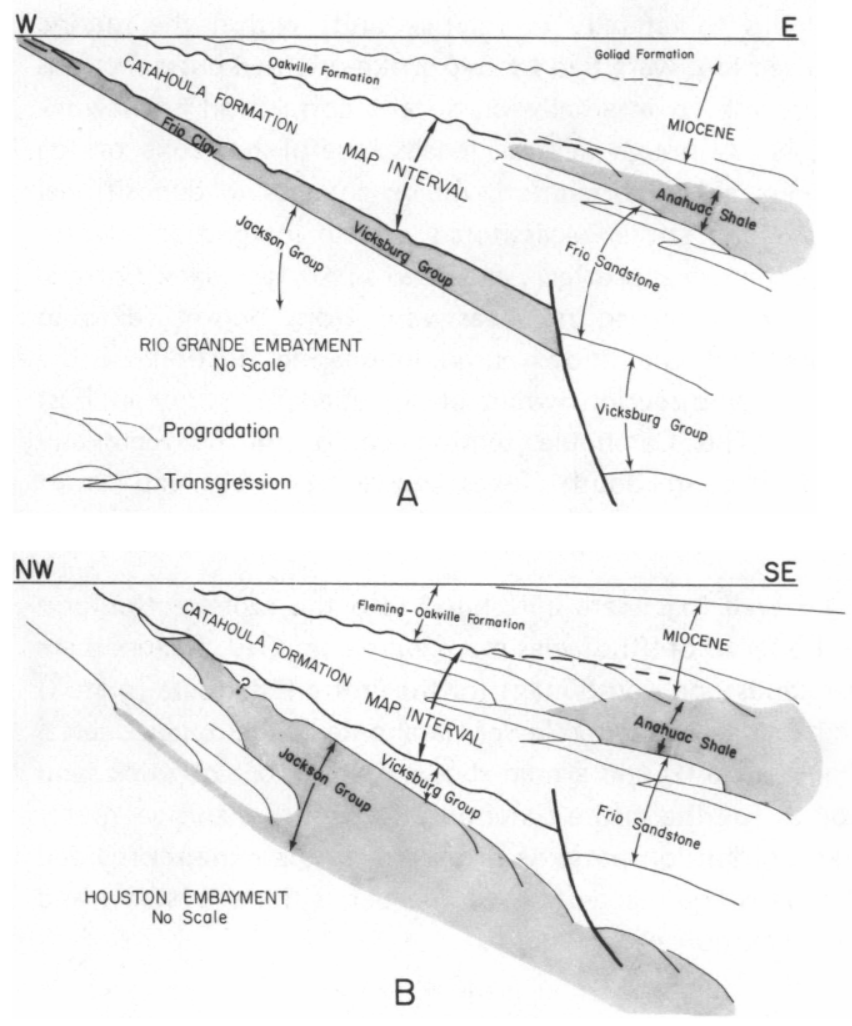

Figure 2. Relation of Catahoula to principal surface and subsurface units of the Rio Grande embayment (A) and Houston embayment (B). Sections are schematic.

(Fisher and others, 1969, 1970). In the Rio Grande embayment, a thin interval of mudrock called the Frio Clay separates the underlying Jackson from the base of the Catahoula; basinward the Frio grades, in part, into the Vicksburg section of the subsurface and thickens abruptly across a regional growth fault zone (fig. 2A). The Catahoula Formation is equivalent to the Frio Sandstone of subsurface usage and to the lower part of the Anahuac Shale wedge (see Deussen and Owen, 1939). (Dual usage of the name Frio for two distinct units has produced considerable confusion but is ingrained in the literature.) At the outcrop belt and in the shallow subsurface, the Catahoula is onlapped, locally with obvious discordance, by the Miocene Oakville or by the Pliocene Goliad Formations. Downdip, the upper contact is gradational and merges into the transgressive Anahuac Shale wedge.

In the Houston embayment, the underlying deltaic Vicksburg Formation cannot be traced updip to outcrop except in extreme East Texas, and the downdip thickening is relatively modest (fig. 2B). The Anahuac Shale wedge is a more prominent feature, but correlations again suggest that the top of the Catahoula merges into this transgressive wedge. The Catahoula is overlain by the Oakville or equivalent Fleming fluvial systems in the shallow subsurface.

Numerous local stratigraphic names have been used for Coastal Plain Tertiary units in the literature, and correlations between sections in the Rio Grande and Houston embayments have been somewhat problematical. The problem has been compounded by the differing objectives of stratigraphic analysis (hydrocarbon exploration, ground-water investigation, outcrop mapping). The correlations shown in figures 2 and 3 and used in this report are based on the following premises:

1. The objective of the project is analysis of an interval stratigraphically equivalent to the Catahoula Formation as defined in the South Texas uranium beit.

2. The Catahoula is differentiable at outcrop because of its high content of airborne volcanic ash. No unit above or below contains equivalent quantities of ashy sediment. Thus, the outcrop belt provides a laterally correlative, synchronous tie point for all dip sections.

3. The downdip Anahuac wedge records a regional transgressive event that provides a reasonably synchronous marker throughout the Texas Coastal Plain. Thus, the stratigraphic relationship established in South Texas between the top of the Catahoula and the updip edge of the Anahuac must be carried northeastward along depositional strike into the Houston embayment. The Catahoula outcrop belt and Anahuac-Frio-Vicksburg of the deep subsurface become tie points that must be connected in a similar manner by all dip sections.

Application of these three premises produces a regionally correlative Catahoula interval that is related to traditional outcrop and shallow subsurface nomenclature as shown in figures 2 and 3 . Several points should be mentioned:

1. The Catahoula Formation of the Rio Grande embayment coincides with the Gueydan Formation as defined by Bailey (1926).

2. On and northeast of the San Marcos arch, the Catahoula includes the interval between the Jackson Group and the Moulton Sandstone Member of the Oakville Formation (Renick, 1936). Note that this interval includes the basal Oakville of the subsurface.

3. In the Houston embayment, the Catahoula interval includes parts of both the Catahoula and Jasper aquifers; part of the upper Catahoula includes beds usually shown as Fleming or Miocene on published regional cross sections (Houston Geological Society, 1954). Figures 4 and 5 are $\log$ cross sections in the two embayments and provide reference subsurface correlation sections for the upper and lower coastal plain. 


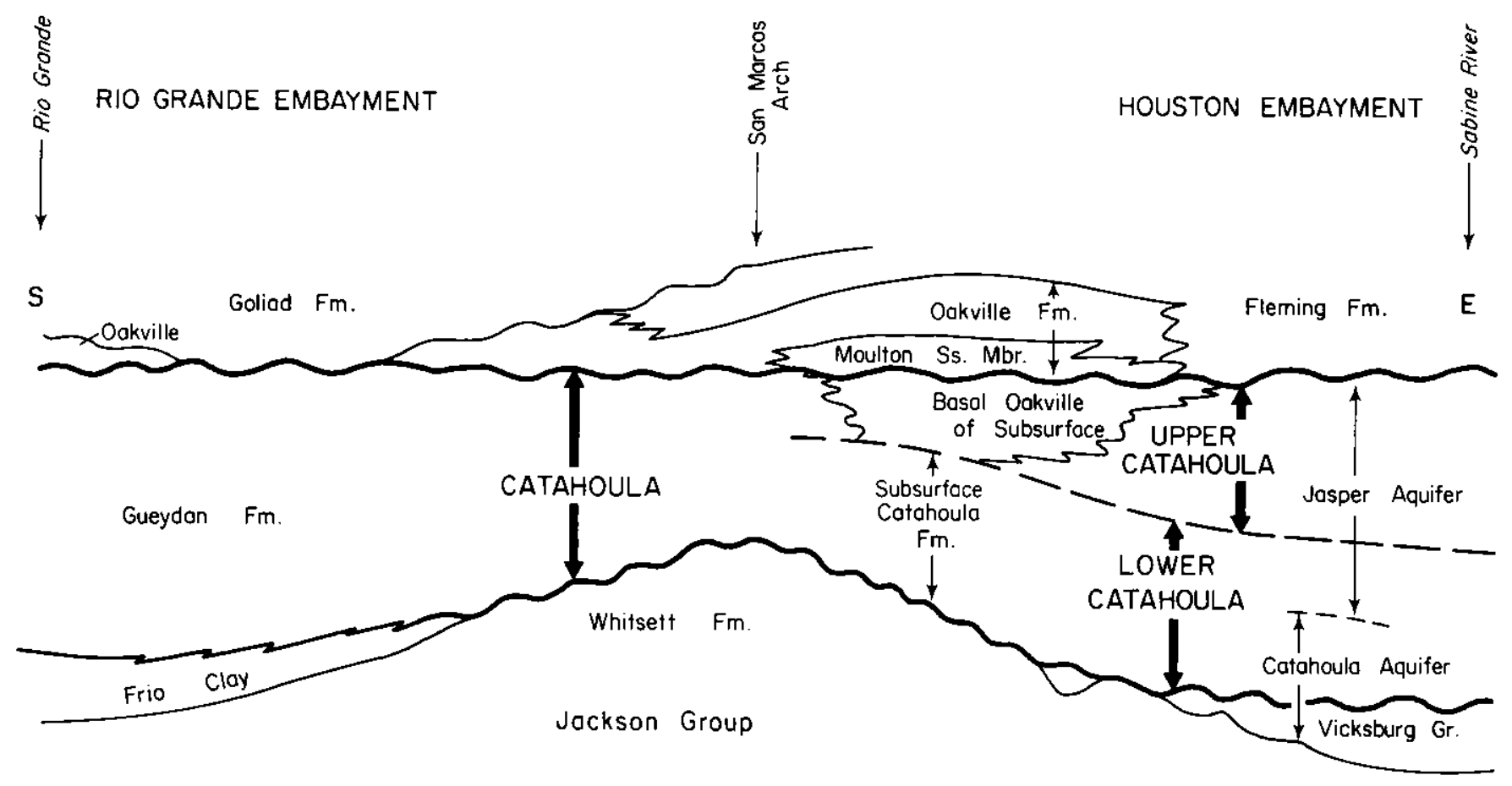

Diagrammatic

Figure 3. Relation of the Catahoula Formation, as defined in this study, to principal surface and shallow subsurface units commonly used in the literature and as delineated on map sheets of the Geologic A tlas of Texas.

\section{CATAHOULA DEPOSITIONAL SYSTEMS}

The concept of natural systems has considerable application to understanding and prediction of uranium mineralization. Chorley and Kennedy (1971) define a system as a structured set of objects, attributes, or both, which display recognizable interrelationships and operate together as a complex whole.

The concept of an ancient depositional system was introduced by Fisher and McGowen (1967) as a genetically defined, three-dimensional, physical stratigraphic unit that consists of a contiguous set of process-related sedimentary facies. Depositional systems constitute the stratigraphic equivalent of major geomorphic features, such as a deltaic, fluvial, or shelf system, and thus are principal building blocks of the total sedimentary basin fill. Although not a requirement of the definition, terrigenous depositional systems analysis is most usefully applied where the boundaries of major systems are preserved and where geometry and composition of principal framework sands have been mapped in some detail. Where an adequate data base for determination of rock unit geometry, composition, and vertical and lateral relations to other units is present, genesis of the units can be interpreted, and reasonable process relationships between such genetic facies can be confidently inferred. Interdependence of component facies is an inherent and diagnostic property of all depositional systems.

Because depositional systems are genetically defined, they are process-response systems that describe the interrelationships between form and process. Process-response systems can be contrasted with morphological systems, which consist solely of a network of structural relationships between constituent parts of a system (Chorley and Kennedy, 1971). Of the two, a process-response system provides a more powerful tool for prediction and interpretation because it allows nonrandom extrapolation beyond the data base and prediction of properties not used in the original definition of the system. For example, interpretation of a stratigraphic sequence as a fluvial depositional system permits prediction of the likely distribution of organic debris or direction of permeability anisotropy or extrapolation of downdip changes in sand body geometry; a descriptive facies map, which defines a morphological system, allows no such prediction unless these parameters are included in the original definition of the mapped facies. 


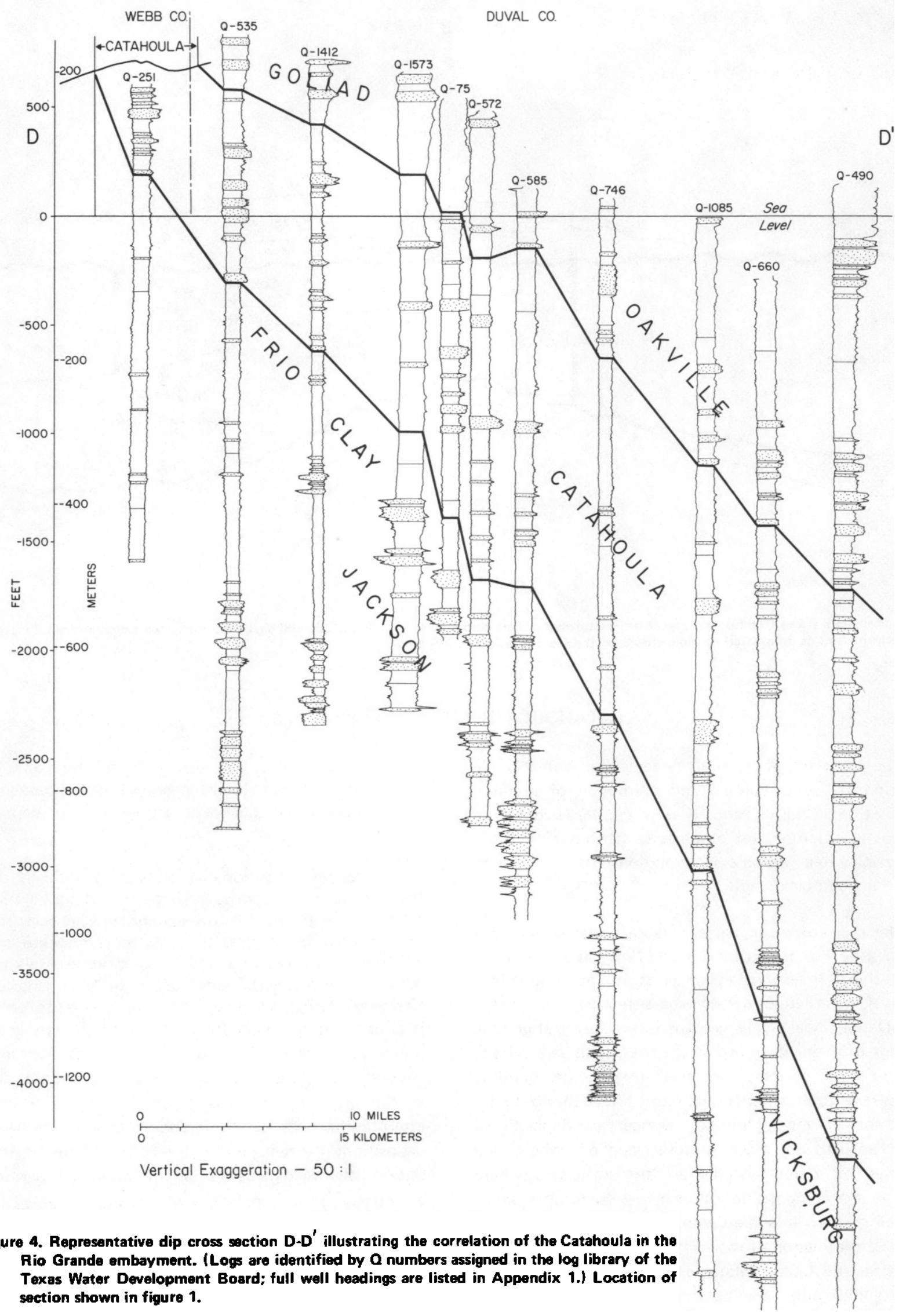




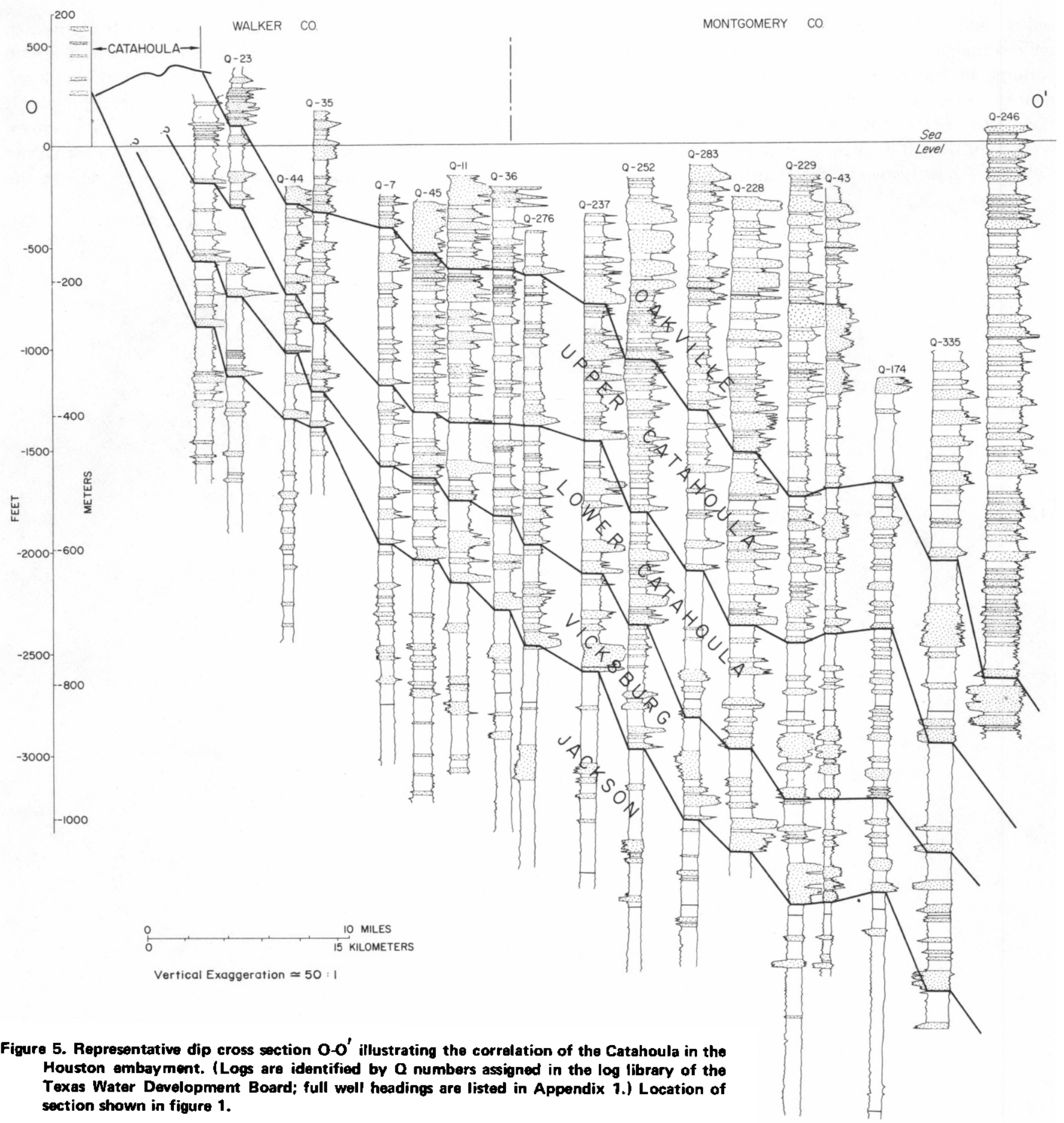

Finally, an ancient depositional system, being a stratigraphic entity, is static. Its defining characteristics are not changing through geologic time in response to continued input of energy or mass. This is in marked contrast to dynamic systems, such as a ground-water flow system, in which both process and response vary throughout the history of the system as a result of changing structural configuration, climatic regime, and degree of consolidation. As will be shown, uranium deposition is a complex response to interactions between both static and dynamic geological systems.

Terrigenous clastic depositional systems are defined on the basis of lithic composition, position in the depositional basin, geometry of framework elements (usually sands), and internal sedimentary features. Synthesis of sand 
isolith and sand body thickness data, reconnaissance sedimentologic outcrop descriptions, and electric log patterns in the context of the regional geologic setting defines two depositional systems in the Catahoula Formation of the Texas Coastal Plain (fig. 6): the Gueydan fluvial system of the Rio Grande embayment and the ChitaCorrigan fluvial system of the Houston embayment. These systems interfinger along the western margin of the San Marcos arch. Both systems grade downdip into the Frio deltaic and barrier-strandplain systems. Regional interpretive log cross sections, such as illustrated by figure 7 , show that facies tend to stack vertically within each system. Consequently, it is possible to define smaller areas within each system in which a particular facies dominates the

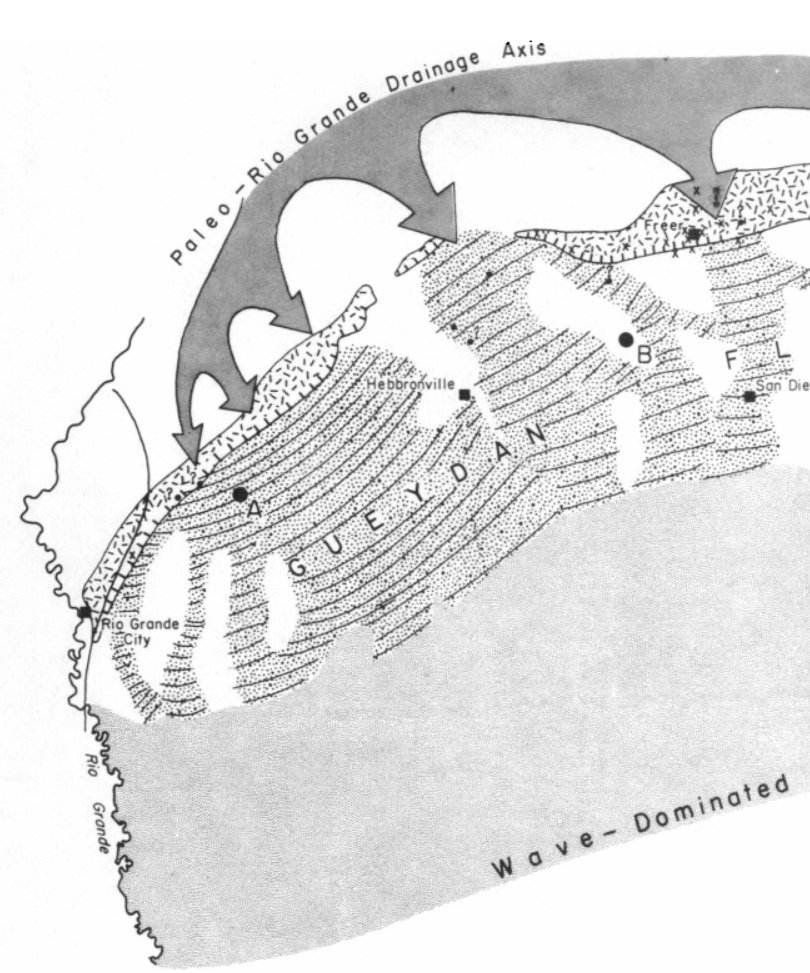

CATAHOULA - FRIO

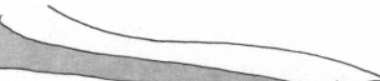


entire Catahoula interval and to display major facies relationships in map view.

\section{GUEYDAN FLUVIAL SYSTEM}

The Gueydan fluvial system, named for the Gueydan Formation with which it is coincident, covers approxi- mately 9,000 square miles $(23,000 \mathrm{sq} \mathrm{km})$ in Starr, Jim Hogg, Brooks, Webb, Duval, Jim Wells, McMullen, Live Oak, Bee, Karnes, Goliad, and southern DeWitt Counties (fig. 6, plate I). The system consists of complexly interweaving, dip-oriented sand belts that tend to diverge from a point-source northwest of the modern outcrop belt in Webb and Jim Hogg Counties. An isolated but prominent sand

\section{DEPOSITIONAL SYSTEMS}
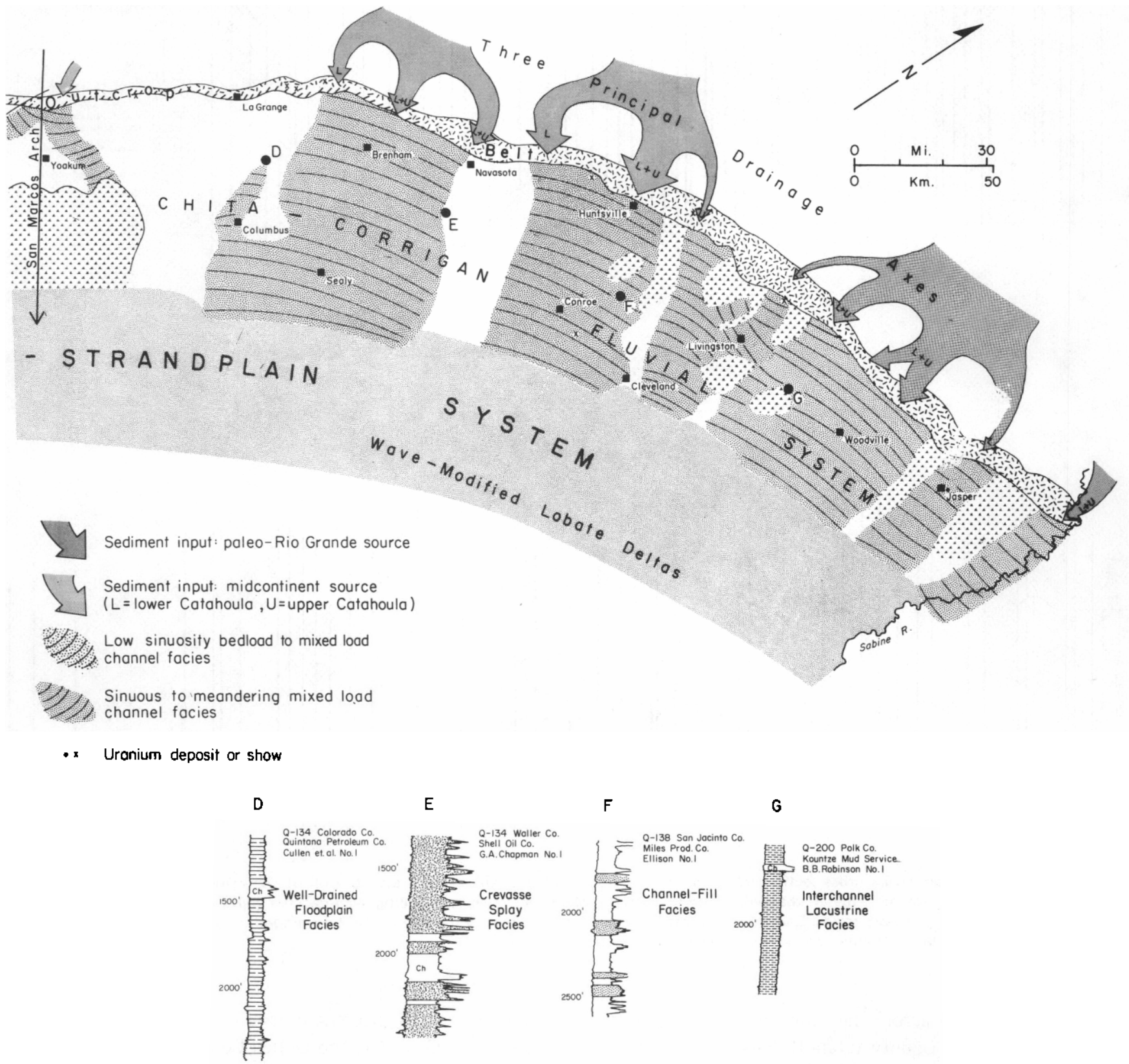

Figure 6 continued 

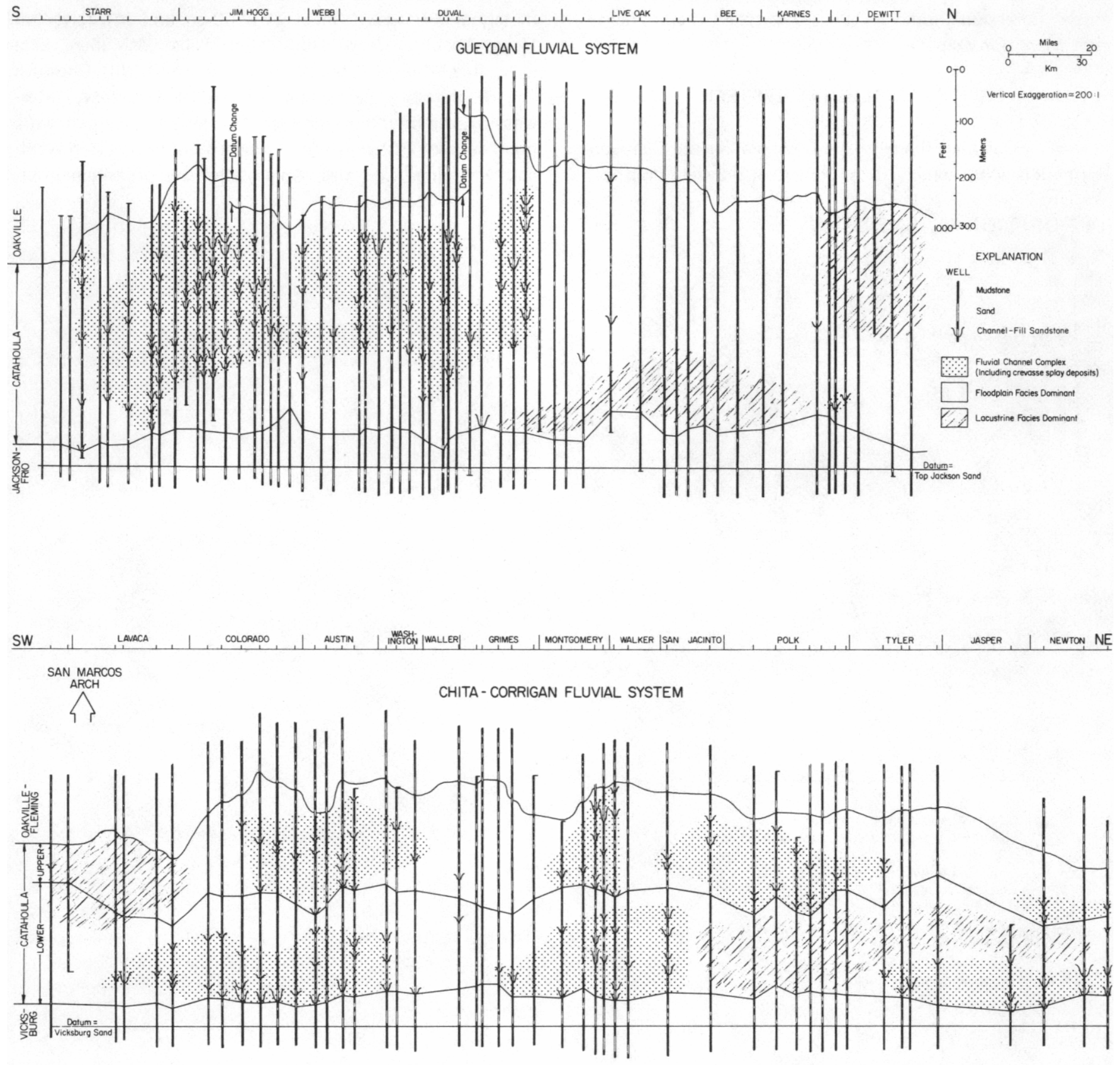

Figure 7. Regional shallow strike cross section (U-S) of the Catahoula showing the vertical distribution of the principal component facies of each depositional system. Fluvial channel-fill units tend to stack vertically producing well-defined belts dominated by fluvial and associated proximal crevasse sands. Lacustrine deposits are also spatially segregated and are best developed in areas farthest removed from contemporaneous fluvial channel complexes. Location of section shown in figure 1.

belt trends obliquely across the outcrop belt and shallow subsurface in Karnes County (plate I). Sand content ranges from a maximum of about 50 percent of the total Catahoula section to less than 10 percent of the section. The number of sand units $30 \mathrm{ft}$ or more in total thickness exhibits a comparable pattern (plate III); as expected, the number of thick sand units is greatest along the sand isopach axes. A prominent sand-poor embayment extends across Live Oak, Bee, and Goliad Counties.

The Gueydan fluvial system includes in vertical succession the Fant Tuff, Soledad Conglomerate, and Chusa Tuff members of the Catahoula Formation (as defined by Bailey, 1926). Coarse clastics are concentrated in but not 
confined to the middle or Soledad portion of the section (figs. 4 and 7) and consist of broad, lenticular units of intermixed sandy conglomerate, pebbly sand and sandstone, and coarse to fine sand and sandstone. ${ }^{1}$ Sand units are interbedded with massive, crudely bedded, and lenticular units of tuffaceous mudstone and claystone with subordinate amounts of tuff, ash, and silt. Sand-rich framework elements of the Gueydan system include bedload channel-fill and crevasse splay facies. Nonframework facies include floodplain tuffaceous mudstone and coastal plain lacustrine tuffaceous mudstone and claystone.

\section{Fluvial Channel-Fill Facies}

Fluvial channel-fill deposits are the predominant coarse clastic facies in the Gueydan system. Thickness of channel sand units averages about $35 \mathrm{ft}(11 \mathrm{~m})$, but single sand bodies over $60 \mathrm{ft}(18 \mathrm{~m})$ thick are common. The base of the sand units is erosional and low relief. Many of the thick sand bodies display an equally sharp top, as well as the more typical transitional or fining-upward patterns which are expressed by e-log patterns (fig. 6). Width of individual sand bodies is difficult to determine with the well control density used, but regional map patterns and detailed examination of local areas of dense well control suggest order-of-magnitude widths of $10^{3}$ feet or meters. Thus width/thickness ratios of the channel-fill units are quite high. Detailed mapping and outcrop patterns also indicate the development of multilateral sand belts several miles wide composed of numerous individual channel-fill units.

Bedload channel-fill sequences consist of coarse to medium sand with subordinate sandy cobble to granule conglomerate and very fine sand and silt. Tuffaceous mud clasts and sand-sized mud pellets are very common. Initially sands were moderately to well sorted, but subsequent diagenetic alteration of unstable rock fragments, clay authigenesis, and squashing of the mud pellets and clasts have typically produced a poorly sorted, matrix-rich sand. Vertical textural variations are erratic. Most sequences display at least a crude fining-upward trend, but grain size and sorting can vary widely within any part of the sand body.

Internal stratification types include common largescale trough crossbeds or cut-and-fill structures, complex crosscutting scour surfaces, abundant planar or low-angle parallel stratification, and low-angle bar accretion bedding.

\footnotetext{
${ }^{1}$ Sand and sandstone are used to denote relative degree of induration of the sediments. Sands are unconsolidated or very loosely consolidated, whereas sandstone is sufficiently indurated to break into coherent blocks. A similar distinction is applied to finer grained sediments.
}

Small-scale sedimentary structures are relatively uncommon, but include small-scale trough, ripple, and parallel lamination. Subsidiary structures include vertical claystone dikes ranging from a few feet to tens of feet in length, common root casts which weather out because of slight differential cementation by authigenic clay, armored tuffaceous mud balls, tuffaceous mud clast conglomerates, and scattered, large mudstone blocks. Laterally extensive, complex erosional surfaces are common within channel-fill sequences, suggesting multiple reactivation of river bed scouring and infilling.

Spatial organization of sedimentary structures is difficult to determine in the typically poor exposures of the South Texas Coastal Plain. Basal Catahoula channel fills have been exposed by uranium mining in Karnes County (fig. 8). Though these exposures are on a divergent channel axis at the margin of the Gueydan system (plate 1), they appear to be representative of the channel-fill facies. The channel sequence consists of three parts (fig. 8):

1. Lower channel fill is characterized by large-scale trough cross-stratification generated by subaqueous dune migration, laterally extensive scour surfaces, and abundant mud clast zones. Sands are medium to coarse grained and typically pebbly. Sandy gravel may be abundant.

2. Lateral bar deposits consist of broad lenses of planar and low-angle accretionary stratification punctuated by localized scour fills. Localized scouring is of two types. High-angle, spoon-shaped scours occur in flocks (fig. 8A) and are associated with dense root casts suggesting scour by stationary turbulent eddies in or behind vegetated parts of the lateral bar. Broad scours characterized by irregularly scalloped basal surfaces and complex internal stratification occur within the bar sequence (fig. 8B, no. 1) and were produced by migrating turbulent eddies. The bar overstepped the underlying channel fill by lateral accretion as the channel axis migrated. The bar sequence consists of interbedded medium to coarse sand containing abundant small to medium tuffaceous mud clasts, chips, and pellets. Granule or pebble gravels are volumetrically minor, but occur locally.

3. Top stratum deposits accreted vertically on the bar surface during flood stage and consist of massive to parallel bedded, fine to very fine sand and silt. Small-scale primary structures may be present, but are difficult to recognize because of the intense argillization of these fine sands and silts. Figure $8 \mathrm{C}$ illustrates a small, symmetrically filled channel likely developed as a flood runoff feature.

The channel sequence shows a crude fining-upward trend. As pointed out by Jackson (1976), however, vertical sequence can vary markedly within a single channel segment. Alternation of this fining-up cycle with more sharply bounded cycles should be expected in coarse- 


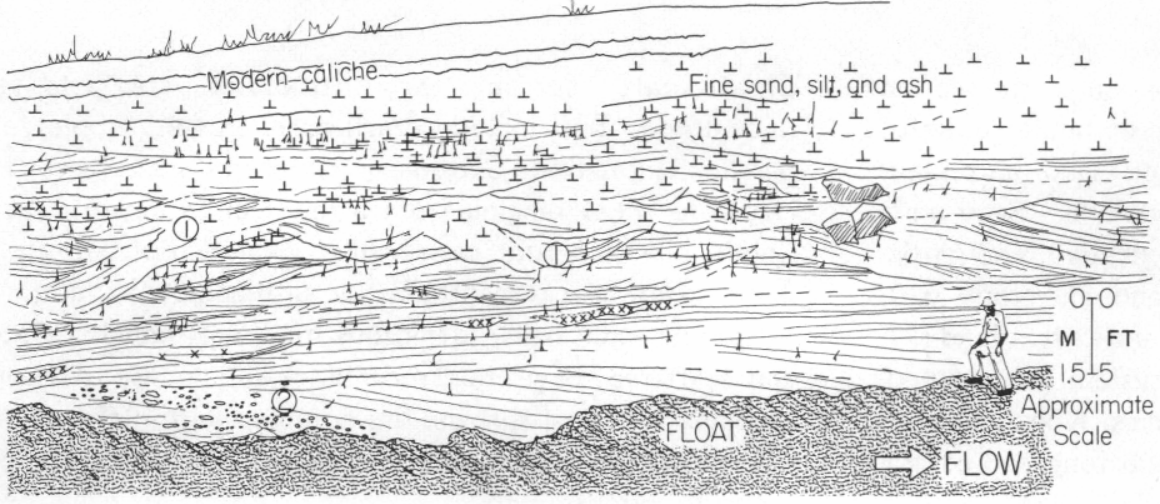

\section{EXPLANATION}

$\perp_{\perp}$ Young calichification

thd Root casts

$x^{x} x^{x}$ Tuffaceous mudstone

) Clay dike

A

$\bigoplus$ Bar Accretion

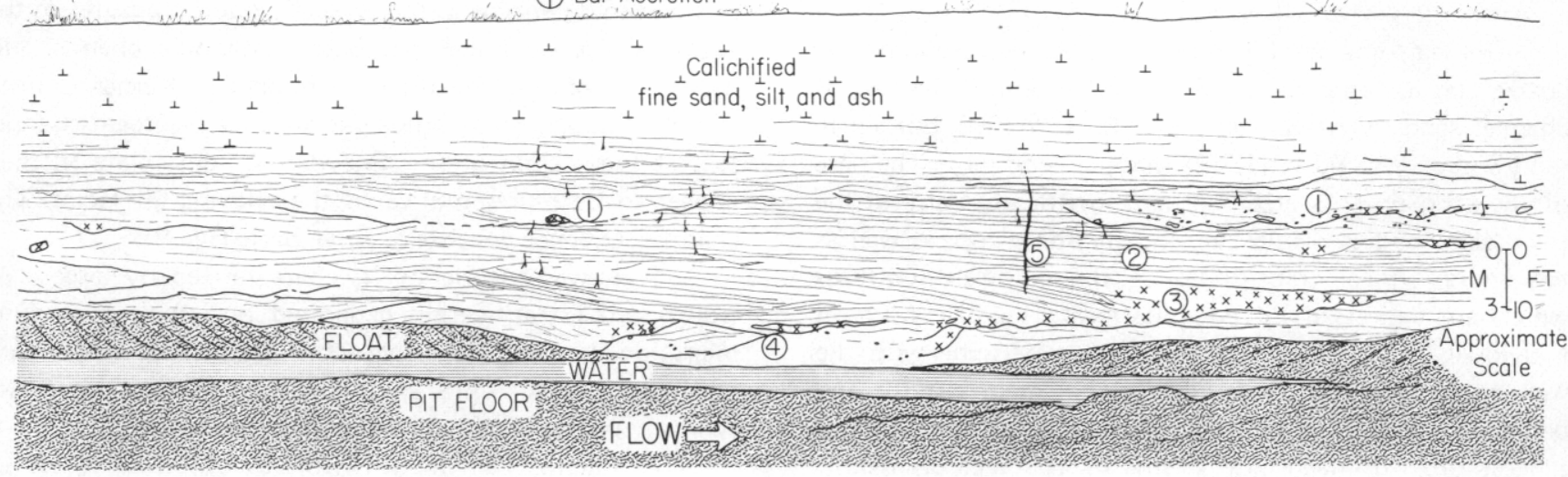

B

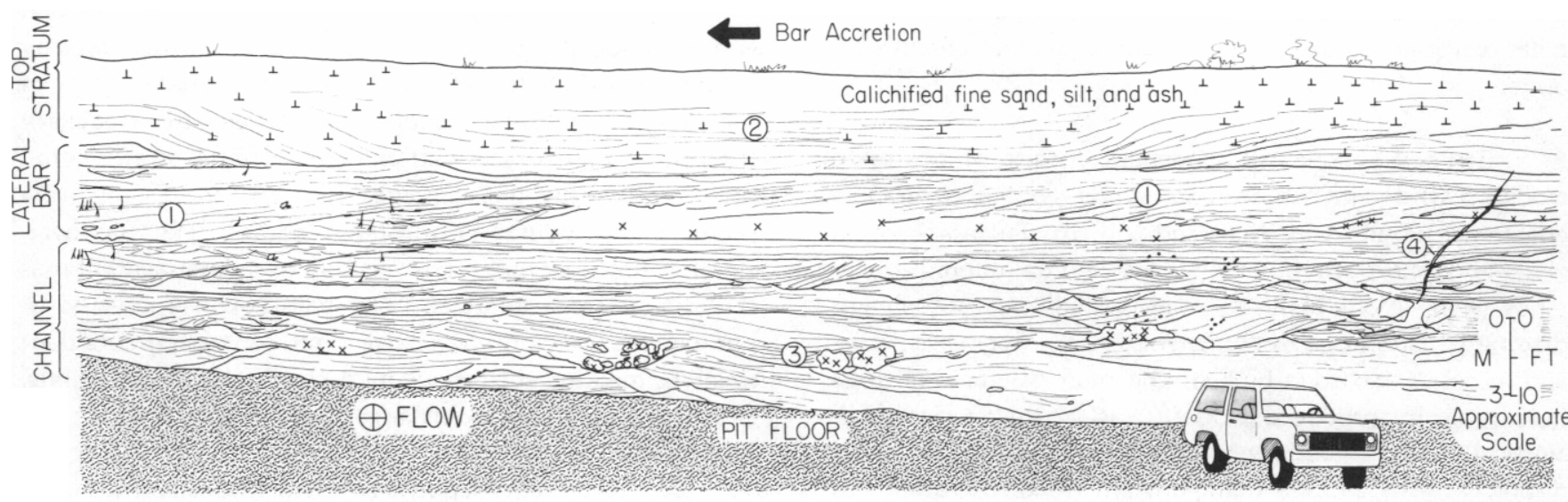

C

Figure 8. Internal structures of Gueydan fluvial bedload channel fill exposed by uranium mining in southwest Karnes County. A and B parallel the paleocurrent direction (left to right). The base of the channel lies a few feet below the top of the float. C illustrates a section at right angles to the paleocurrent direction; channel, lateral bar, and top stratum deposits can be distinguished by grain size and internal structures. Significant features include: A. (1) Scour pool cross-stratification formed on the lee side of an obstruction, probably in situ brush or small trees (note abundance of root traces). (2) Abundant tuffaceous mud clasts incorporated in large-scale cross-stratified coarse to medium sand. B. (1) Broad, irregular scour-and-fill units displaying scalloped basal surfaces and containing abundant tuffaceous mud clasts of various sizes. (2) Thick, laterally continuous planar bed sets consisting of interlaminated medium and coarse sand. (3) Compacted ash pellet sand at toe of large scour trough. (4) Large-scale lenticular trough cross-stratification sets typical of the lower channel fill. (5) Intrastratal clay dike. C. (1) Low-angle accretionary bedding indicative of lateral bar migration from right to left into the channel. Note reactivation surfaces. (2) Symmetrical swale fill in fine sand and silt of the top stratum. (3) Interchannel scour surface littered with large blocks of tuffaceous mudstone eroded from the channel banks. (4) Intrastratal clay dike. 
grained, high bedload fluvial systems (Brown and others, 1973) and is suggested by the intermixing of blocky and transitional log responses observed in the Gueydan fluvial channel facies (fig. 6).

\section{Crevasse Splay Facies}

Recurrent flooding in the Gueydan fluvial system resulted in flow breaching the broad, poorly developed natural levees, spreading over interchannel areas, and depositing extensive aprons of ash-rich fine sand and silt along the flanks of major channels. Such crevasse splays extend up to $10^{3}$ to $10^{4}$ feet or meters beyond channel margins and average a few tens of feet thick. Thickness is quite variable locally because of the complex internal structure of splays, which consist of narrow anastomosing channel fills as much as $30 \mathrm{ft}(9 \mathrm{~m})$ thick, separated by thinner sequences of irregularly bedded sheet flow and paleosoil deposits. Widths of crevasse channel fills range from a few feet to a few hundred feet; in contrast to the associated fluvial channels, the width/thickness ratio is very low.

Crevasse splay deposits consist of a variety of sediment types, ranging from medium or fine sand and sandstone to mudstone, reflecting the heterogeneous depositional conditions typical of the crevasse environment (Coleman, 1969). In addition, diagenetic alteration of the ash-rich crevasse sediments has dramatically altered original sediment texture. Crevasse channel fills range from tuffaceous fine to medium sand and sandstone to sandy tuffaceous mudstone and claystone. Crude fining-upward sequences are common. Weathering surfaces suggest that significant thicknesses of tuff-ball conglomerate (the lumpy pisolitic tuff of McBride and others, 1968) filled some crevasse channels; lenses of relatively unaltered ash also occur locally. Petrographic study indicates that the tuffaceous fill sediments were originally deposited as fine sand to silt-sized volcanic ash and ash pellets that have subsequently altered to montmorillonitic clay.

Crevasse channel fills may be massive and unbedded (fig. 9) or may display symmetrical to irregular, lenticular bedding. Local internal scour surfaces are indicated by discontinuous lags of large tuff clasts or micrite nodules. The channel fill is typically highly lenticular with steep erosional margins (fig. 9); multiple, laterally connected lenses (fig. 9, unit IV) indicate the anastomosing nature of the channel networks. Root casts and other pedogenic features are common in upper parts of the fill. Crude bedding and interlensing of various lithic types typify interchannel deposits. Intense root disturbance and diagenetic alteration obscure many small-scale sedimentary structures, but ripple lamination, parallel lamination, and broad, shallow scour-and-fill structures are preserved in sandier crevasse deposits. A typical electric log through crevasse splay facies is shown in figure 6 .

\section{Floodplain Facies}

Fluvial channel fills and their flanking crevasse splay aprons are surrounded by thick, laterally discontinuous sequences of tuffaceous mudstone, muddy siltstone, and bentonitic claystone deposited in the interchannel environment during flood discharge land possibly by direct ash fall). Local zones of micrite nodules and fine to medium root casts indicate some pedogenesis (soil formation), but paleosoils are not well developed. Pedogenesis and argillation of the fine ash have obscured primary sedimentary structures. Floodplain deposits are typically massive to crudely bedded and internally homogeneous. Locally, soil-like pedal structures and some ripple or wavy lamination were observed. Finely divided hairlike root structures are common, but distinct rooted horizons are rarely as pronounced as in the crevasse splay facies.

\section{Coastal Lake Facies}

Characteristic coastal lake deposits are exposed in outcrop at the base of the Catahoula across northern Live Oak County (fig. 6) and can be traced into the shallow subsurface in open uranium pits. The sand-poor area mapped in southern Live Oak, Bee, and Goliad Counties (plate 1) suggests that this lacustrine facies is part of a persistent regional embayment or zone of general fluvial channel bypass that lies landward of the well-developed strike-fed Frio barrier-strandplain complex of the deeper subsurface. The coastal lake facies covers approximately three hundred square miles ( 800 square $\mathrm{km}$ ) and comprises as much as several hundred feet of lower Catahoula deposits (fig. 7). A similar facies appears to be present in the subsurface in DeWitt and Victoria Counties along the western margin of the Chita-Corrigan fluvial system (figs. 6 and 7). Localized coastal lake sequences may also occur in downdip portions of the main Gueydan system to the south.

The coastal lake facies consists of two end member subfacies: (1) lake-basin bentonitic clay and claystone and tuffaceous mudstone, and (2) lacustrine delta (typically a prograding crevasse splay) tuffaceous mudstone, siltstone, fine to very fine sand, and ash. The two subfacies are intimately interbedded units ranging from less than a foot to a few tens of feet thick (fig. 9, units I and II). Carbonate nodule-bearing zones are common, and diffuse carbonate or opaline cement may surround the base of small delta distributary channel units (fig. 9, unit I, for example). 


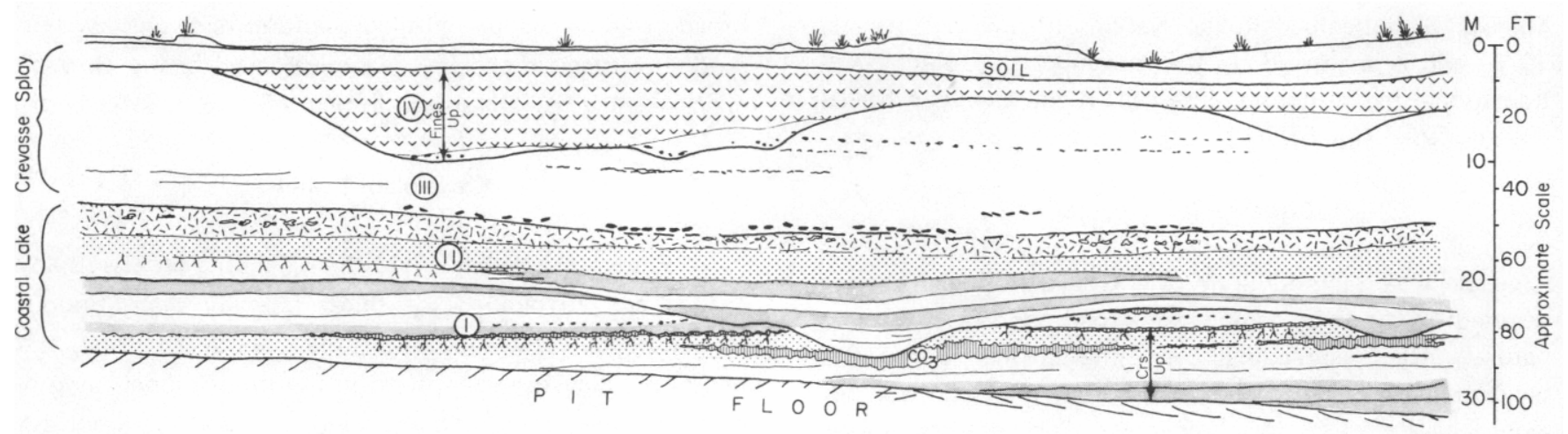

Fine sand to silt
Reduced mudstone to sandy mudstone

Figure 9. Section of basal Gueydan crevasse splay facies overlying bedded deposits of the coastal lake facies exposed by mining in northern Live Oak County. Four principal depositional units are delineated. Unit 1 consists of interbedded claystone, mudstone, and siltstone deposited in a lacustrine environment. Thin coarsening-upward sequences capped by root horizons indicate local pulses of progradational sediment infilling. Unit II was deposited as part of a progradational crevasse splay that infilled the lake basin. Small channels filled by interbedded mud and clay were local, small distributaries of the crevasse. The sequence is capped by a primary oxidized, siliceous and calcareous paleosoil horizon. Unit III was deposited by a major crevasse splay and consists of a basal scour surface, locally littered by reworked micrite nodules, overlain by a homogeneous section of silty mudstone deposited in both crevasse channel and interchannel environments. Local zones of pedogenic micrite nodules occur in the upper half of the unit. Unit IV consists of a lenticular structureless mud-filled crevasse channel fill. The channel was a suspended load type, as shown by the low width/thickness ratio, and anastomosing pattern producing the multiple thalwegs along the basal scour surface.

Lake-basin depositional sequences consist of interbedded clay, claystone, and mudstone containing local lenticular beds of ashy silt or very fine sand. The beds include a variety of small-scale primary structures including horizontal, ripple, starved ripple, and wavy lamination, small injection and load structures, abundant fine root traces, and rare, local burrowed zones. Clays are blocky and slickensided. Lacustrine delta deposits consist of tabular, coarsening-upward sequences displaying fine-scale structures, abundant root traces, and local infilled scour troughs. This regular vertical sequence is interrupted laterally by numerous lenticular distributary channel-fill deposits up to $20 \mathrm{ft}(6 \mathrm{~m})$ thick and 10 to $100 \mathrm{ft}(3$ to $30 \mathrm{~m}$ ) wide, which commonly display medium-scale trough cross-stratification, crosscutting scour surfaces, and ripple cross-lamination. Distributary channel units commonly contain symmetrical fill and, like their crevasse splay counterparts, may occur in laterally connected groups of two or more (fig. 9, unit 1). Although the channels are separated from underlying lacustrine mudstone and claystone by a distinct scour surface, the base of the channel fill typically contains a thin transition zone rather than a coarse basal lag. Sandy distributary channel fills tend to fine upward and grade into homogeneous, root-disturbed mudstone and siltstone.

The coastal lake facies is characterized by repetitive, thin, coarsening-upward sequences, well-developed medium to thin bedding, abundant, massive bentonitic clay, and ubiquitous fine-scale roots. E-log patterns reflect the coarsening-up sequences and fine-grained composition of the lacustrine facies and can be used for recognition of the facies in the subsurface (fig. 6 ).

\section{Paleosoils}

Soil-forming processes were quite active in several depositional environments of the Gueydan fluvial system. Pedogenic features occur in the top stratum deposits of fluvial channel fills and in subaerial parts of lacustrine deltas; they are ubiquitous attributes of crevasse and floodplain facies.

Gueydan paleosoils display features typical of vertisols, which commonly form in arid to semiarid areas (Fitz Patrick, 1971). Common features include calcium 
carbonate concretion zones, grassy vegetal cover (producing fine-scale root systems), and well-developed churned or pedal structure. Montmorillonite is the major mineral constituent. Significantly, vertisols are dark colored but contain little organic material.

Additional features of Catahoula mudrocks, indicative of paleosoil formation (Brewer, 1964), include:

1. Common vugs and vesicles.

2. Abundant clay cutans (segregations of colloidal clay minerals) around detrital grains, interiors of root tubules, and fracture surfaces (surfaces of soil peds).

3. Colloidal clay segregations infilling voids and root tubules.

In environments characterized by repeated wetting and drying, such as levee and proximal crevasse areas, highly leached, oxidized soil zones developed. These oxidized paleosoils are characterized by red, brown, or bleached coloration (even where found in a regionally reduced section) and display intense carbonate and silica cementation and nodule formation (fig. 9, unit II).

\section{Facies Associations and Distribution}

Figure 10 illustrates a composite cross section of a Gueydan channel complex and associated facies. Fluvial channel-fill sands, typically occurring in multilateral offset belts, are bounded by laterally equivalent crevasse splay deposits. Proximal crevasse channel deposits may be sand (section D) or ash and mud filled (section B) and are concentrated along fluvial channel margins and down the axis of large crevasse splays. Distal crevasse splay siltstone and mudstone (section $\mathrm{A}$ ) are interbedded with fine-grained floodplain facies (or with the coastal lake facies). Sand isolith maps of the Gueydan will probably include proximal crevasse sands and silts along with the fluvial channel fills.

Vertical persistence of environments (fig. 7), a typical attribute of Gulf coast depositional systems (Fisher and others, 1969), results in some areal segregation of superimposed facies within the Gueydan depositional system (fig. 6). The southern two-thirds of the system consist primarily of stacked sequences of fluvial channel-fill and crevasse facies encased in thick floodplain deposits. The

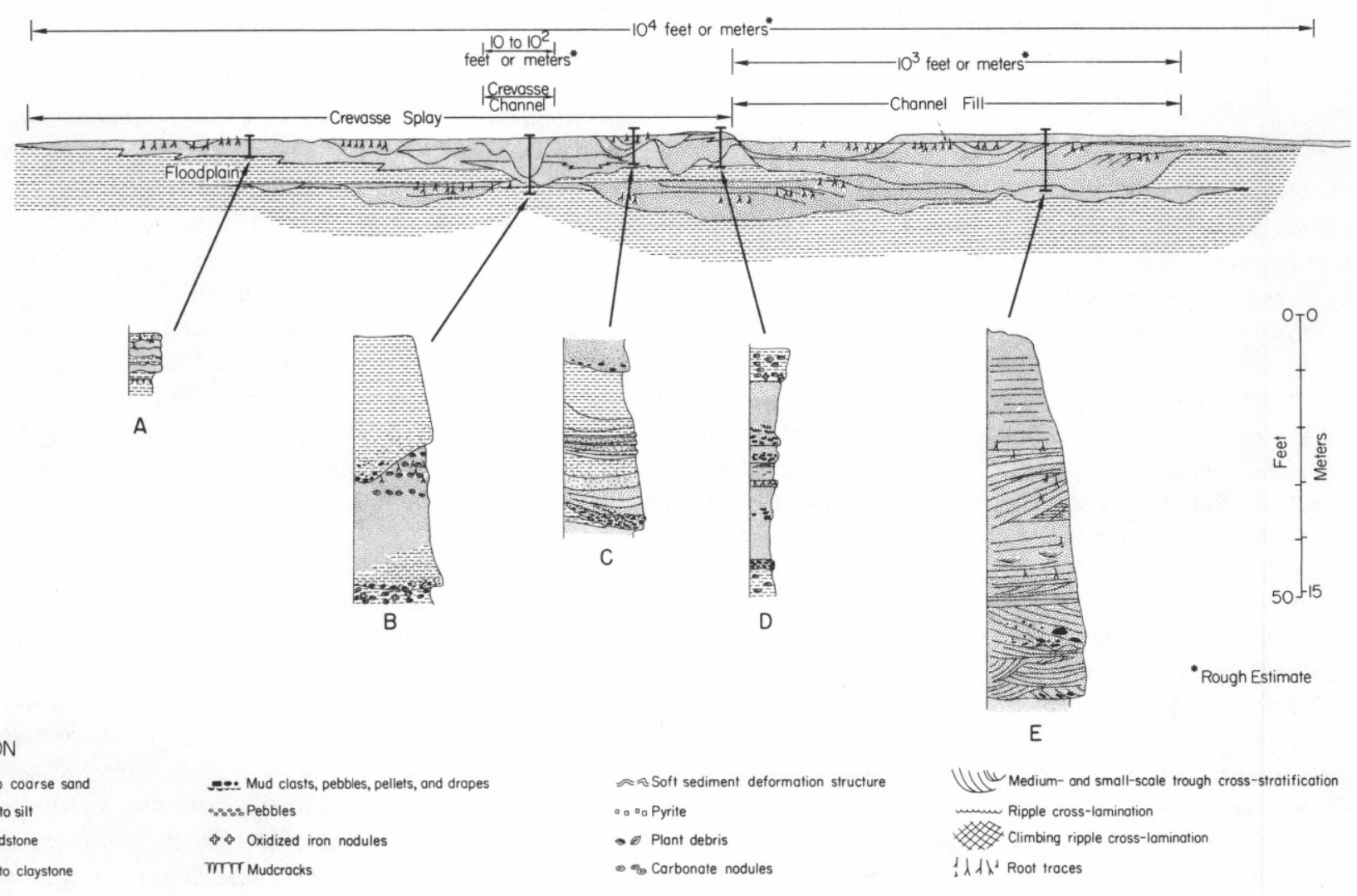

Figure 10. Composite cross section of a Gueydan fluvial channel complex illustrating lateral relationships of the various facies discussed in text. Channel-fill and erevasse deposits form the sand framework of the system. Measured sections illustrate sedimentary features of distal crevasse (A), proximal crevasse tuffaceous mudstone-filled channel (B), mixed sand and mudstone-filled channel (C), sand/silt-filled channel (D), and fluvial channel-fill deposits (E). Section localities are described in Appendix 2. Dimensions suggest order-of-magnitude widths of the channel complex and component facies. 
southern margin of the system lies along the modern Rio Grande where channel sand belts grade abruptly into a sand-poor sequence (plate I). The northern part of the system consists of an updip sequence of well-developed, coastward-trending crevasse splay deposits, which were prograded along their distal margins into the thick, mudrich coastal lake facies. Note that the boundary between crevasse and coastal lake facies shown on figure 7 is arbitrary; the two facies likely interfinger over a broad area. The Gueydan coastal lake facies is best developed in the lower part of the Catahoula section (fig. 7). Breakup of fluvial sand belts south of Cuero in DeWitt and Goliad Counties (plate I) indicates distributary development as paleochannels encountered the coastal lake environment, further suggesting the significance and persistence of this local depositional basin.

Fluvial and coastal lake facies grade basinward into sands and muds of the Frio delta/strandplain system. Sand isolith patterns and e-log patterns (Bebout and others, $1975 \mathrm{a}, \mathrm{b})$ indicate the formation of wave-dominated delta lobes where the Gueydan channel systems drained into the Gulf of Mexico. The thickness of Frio deposits expands manyfold in response to a succession of growth fault zones.

\section{Environmental Reconstruction}

Principal depositional environments in the Gueydan fluvial system included fluvial and associated crevasse, interchannel floodplain, and coastal lake environments. Characteristics of each of these environments can be inferred from the geometry, composition, and internal sedimentary features of resultant facies.

Schumm (1972) classified alluvial channels as bedload, mixed load, or suspended load depending on the relative proportion of suspended load (silt and clay) and bedload (sand and gravel) transported by the stream segment. This classification can be applied to stratigraphic interpretation of fluvial channel sequences because relationships exist in depositing streams among amount of fine (suspended load) sediment deposited as a part of the channel fill, the tendency of the river to erode or deposit material along its base or banks, and the sinuosity of the channel. The last two parameters affect geometry of the resultant channel-fill deposit; percentage of suspended load deposited in the channel determines the textural composition, and in turn, the net permeability and porosity of the channel-fill sequence. These parameters are obviously important to uranium exploration. Although true paleochannel dimensions or sinuosity are difficult to determine, a number of stratigraphic criteria (based on the interrelationships between channel geometry and composition and upon analysis of other fluvial systems) are useful for differentiation of bedload, suspended load, and mixed load fluvial systems (table 1).

A number of different fluvial models (for examples, see Brown and others, 1973) exist within each of these three categories, and in fact within a single channel segment (Jackson, 1976; Bluck, 1971). Some generalities may be suggested; bedload streams may fit braided or coarsegrained meanderbelt models, mixed load streams may form fine-grained meanderbelts, and suspended load streams likely will be filled symmetrically and may fit a distributary model.

Using the criteria in table 1, the channel complexes of the Gueydan fluvial system are interpreted to have been deposited dominantly by bedload, straight to slightly sinuous streams (fig. 11). These channels do not, however, contain structures typical of the conventional braided stream models (Brown and others, 1973). Lateral bars developed along channel margins, but meandering was limited and channel sinuosity was low. Levees were unusually broad and well developed for a bedload system as a consequence of the sporadic overbank flooding of ash-laden floodwaters. With levee development, overbank flow became more organized and incised crevasse channels cut through precurser levee/crevasse deposits. Because floodwaters carried relatively fine sediment dominated by fine sand to silt-sized volcanic ash, crevasse channel fills are narrow, highly lenticular, symmetrically filled, and anastomosing (figs. 9, 11) suspended load types. The contrast between Gueydan fluvial channel fill and crevasse channel fill graphically illustrates the extreme facies variation that may be produced by sediment-sorting mechanisms operating within the same fluvial system. Significantly, the multilateral sand belts and surrounding fine sand- and silt-rich crevasse and floodplain deposits created a wellintegrated, permeable aquifer, at least before postdepositional alteration of the ash.

The preserved portion of the Gueydan fluvial system was fed by a single, large, integrated river system that probably originated in the desert southwest, flowed across Trans-Pecos Texas, and entered the Gulf of Mexico along the axis of the Rio Grande embayment (Belcher, 1975). The partially preserved radiating channel pattern (plate I, fig. 6) and the uniform sand mineralogy (discussed under Petrofacies section) both support the interpretation of a single tributary drainage system. Further, reasonable reconstructions of West Texas Oligocene paleogeography, which place the Davis Mountains area at an elevation of approximately $3,000 \mathrm{ft}(900 \mathrm{~m})$ (Belcher, personal communication), result in a valley gradient for this fluvial system averaging $8 \mathrm{ft} / \mathrm{mi}(1.5 \mathrm{~m} / \mathrm{km})$ between Trans-Pecos Texas and the apex of the Gueydan system. Such a gradient 
Table 1. Stratigraphic characteristics of principal stream channel types.

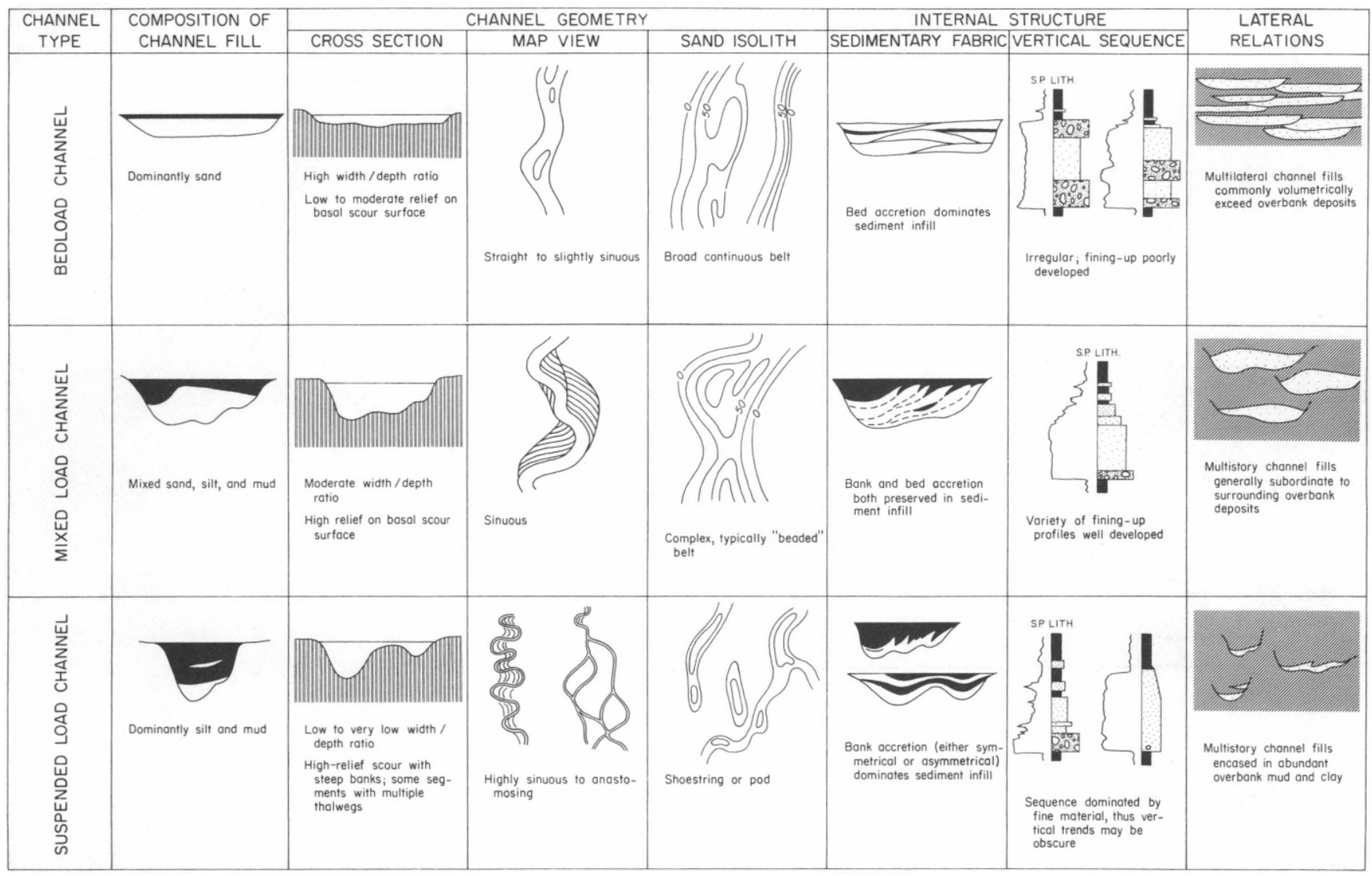

is considerably higher than that of modern Texas Coastal Plain streams and may help explain the competence of Gueydan streams to transport the very coarse debris that has troubled previous workers (Mc8ride and others, 1968; Bailey, 1926).

The climate of the depositional basin was dry as indicated by (1) development of paleosoil profiles rich in montmorillonite and reprecipitated calcium carbonate (Fitz Patrick, 1971); (2) concentration of vegetation (as evidenced by roots) in channel, channel margin, or lacustrine deposits; and (3) preservation of chemically unstable carbonate rock fragments and plagioclase feldspars in the sands.

Fluvial paleohydrology was greatly affected by the sporadic influx of airfall ash in both the tributary and depositional basins. Effects of ash fall on sedimentation have been reviewed by Wilcox (1959) and Davies (1976), among others. Widespread deposition of unconsolidated, easily eroded sediment, with possible concomittant destruction of grassy vegetation and enhanced rainfall lead to the sudden inundation of drainage systems by a flood of sediment-laden runoff. Predictable responses of such a flood-stressed fluvial system would include accentuation of peak discharge with consequent dispersal of a considerable volume of fine bedload and suspended load material into overbank environments, forming extensive crevasse splays dominated by ashy sediment. Unusually coarse sediment could also be transported by the turbulent, sediment-laden waters. The abundance of tuffaceous crevasse splay deposits and common lenses of ashy and tuffaceous sand within the coarse-grained fluvial channel fills demonstrates the highly variable flow conditions typical of the Gueydan fluvial system.

In addition, the large volume of ash, which collected preferentially in overbank environments and subsequently altered to clay, has produced a bedload fluvial system with unusally low sand content.

\section{CHITA-CORRIGAN FLUVIAL SYSTEM}

The Chita-Corrigan fluvial system extends from the San Marcos arch, where a small fluvial complex trends southward and coalesces with a northward-trending 


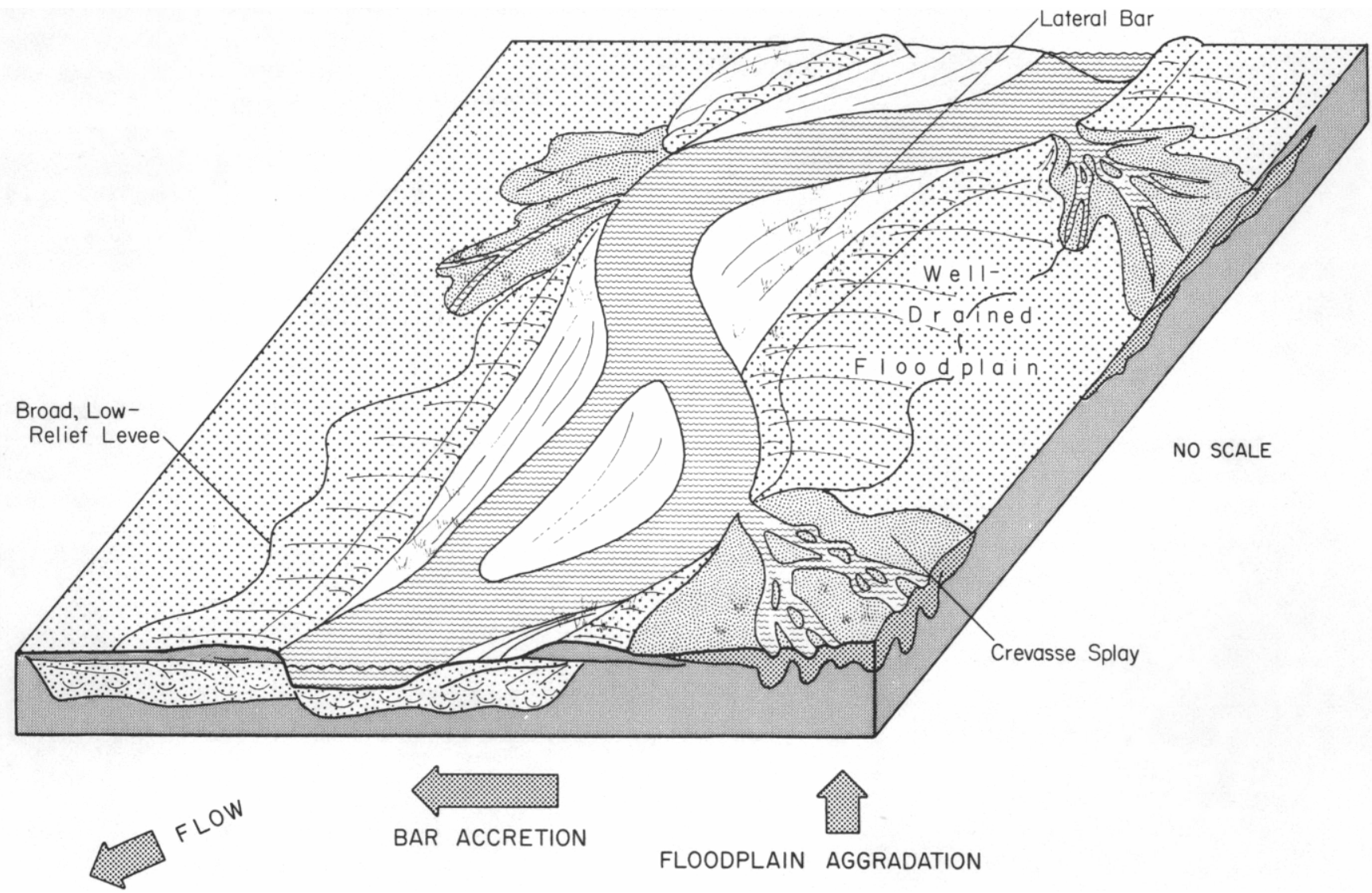

Figure 11. Schematic reconstruction of Gueydan depositional environments. High bedload, low sinuosity channels were flanked by extensive crevasse splays that funneled ash and sand into the surrounding floodplain environment. Vegetation was concentrated along the river course.

Gueydan fluvial axis to the Texas-Louisiana line (fig. 6). It is named for the Chita and Corrigan Sands, two units locally mapped within the East Texas Catahoula. The northeast limit of the system is not clearly defined by mapping; however, the Catahoula and equivalent downdip Frio Formation thin substantially near the state line. The Chita-Corrigan system covers at least 10,000 square miles $(26,000 \mathrm{sq} \mathrm{km})$ in Texas. It grades basinward into an equivalent Frio wave-modified lobate delta system (Bebout and others, 1976). As in South Texas, the fluvial-to-deltaic transition is associated with down-to-the-coast growth faults.

The Chita-Corrigan system consists of stacked sequences of channel fill and associated sands forming several dip-oriented belts (fig. 6), which are separated by mud-rich facies containing thin, discontinuous sand units (fig. 7). Compositionally, the Chita-Corrigan system consists of approximately 35-percent sand and 65-percent mud (as defined by electric log response); locally, sand percentage ranges from less than 10 to more than 50 percent. Up to 10 thick sand units $(30 \mathrm{ft}$ or more thick) occur in a single vertical section (plate III). The number of thick sand units present is generally proportional to the total sand content of the Catahoula section (compare plate III with plate I).

The Chita-Corrigan system includes several locally named members, including the Chita and Dunlop Quarry Sandstones of Renick (1936), Corrigan Sandstone of Kennedy (in Dumble, 1918), and Onalaska Member of Dumble (1918).

Framework facies of the Chita-Corrigan fluvial system include fluvial channel-fill sand and laterally equivalent crevasse splay deposits, which can be differentiated into proximal and distal portions on the basis of sedimentary features and thickness. Nonframework facies include welldrained floodplain mud and silt and interchannel lacustrine clay, mud, and sand. In addition, coastal lake deposits appear to be present in the upper part of the Catahoula in the subsurface near the San Marcos arch (figs. 6 and 7). The 
deposits are presumed to be similar to the coastal lake facies of the Gueydan system.

\section{Fluvial Channel-Fill Facies}

Fluvial channel-fill units form dip-oriented, sinuous sand belts averaging 35 to $45 \mathrm{ft}(10$ to $15 \mathrm{~m})$ in thickness. Approximately 5 percent of the sand bodies are over $75 \mathrm{ft}$ $(23 \mathrm{~m})$ thick. Individual channel fills are lenticular in cross section; widths of the sand units range from $10^{3}$ to $10^{4}$ feet or meters (fig. 12). Margins of the channel-fill units are erosional.

Fluvial channel-fill units commonly stack vertically and produce broad, dip-oriented sand belts (plate 1, fig. 6) that indicate axes of terrigenous sediment input into the basin. Cross section U-S (fig. 7) shows three principál stacked channel sequences in both the upper and lower Catahoula. A broad channel complex extends beneath Colorado and Austin Counties and persists vertically through the entire Catahoula section. A narrower channel complex underlies Montgomery and Walker Counties on the line of section, again persisting throughout the entire
Catahoula interval. A very broad upper Catahoula channel complex underlies Polk and San Jacinto Counties, but the underlying lower Catahoula complex is offset to the east beneath Jasper and Newton Counties (fig. 7).

Channel-fill facies typically consist of subequal portions of medium to coarse sand (containing some sandy granule to small pebble gravel) and fine to very fine sand. Local lenses of mudstone and muddy sandstone, mud clast conglomerate, and muddy granule conglomerate occur in lower parts of the channel fill; clay pellets and chips are common in upper parts. Sands are moderately to well sorted. Ferruginous nodules and fragments of silicified wood are common accessories. At outcrop particularly in central and southern parts of the system, sands are commonly silicified or cemented by white, intergrown clay-chert cutanic coats.

Channel-fill deposits display a variety of sedimentary structures (fig. 12), including medium- to large-scale, lowto high-angle trough cross-stratification, scour and fill, minor planar stratification, and local avalanche crossstratification. Laterally persistent crosscutting scour surfaces floored by basal mud clast and gravel lags suggest

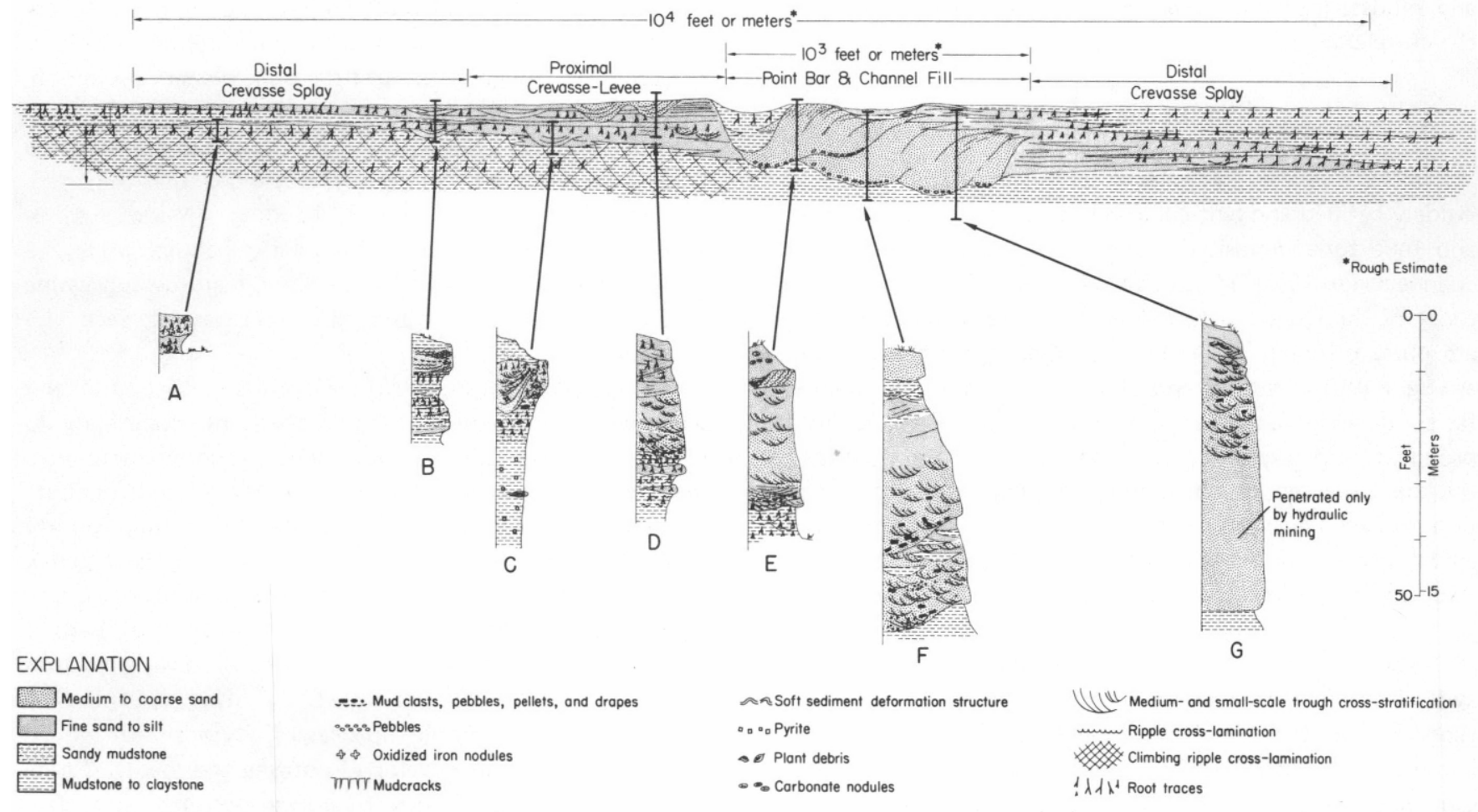

Figure 12. Composite cross section of a Chita-Corrigan fluvial channel complex illustrating lateral relationships of facies discussed in text. The main channel-fill sand unit displays both simple and complex fining-upward sequences (F and $G$ ) as well as local coarse-grained upper point-bar deposits (E). Proximal crevasse deposits consist of lenticular, erosional channel fills (D) where the crevasse cut through levee or older crevasse deposits and coarsening-upward sequences capped by root-disturbed sands and small lenticular distributary channel fills (C) where the crevasse prograded into an interchannel lake basin. Distal crevasse deposits include medium to thick beds displaying abundant smallscale primary structures (B) or intense pedogenic reworking (A). Location of section localities in Appendix 2. 
complex histories of channel fill and reactivation. Smallscale structures are less common, but ripple and parallel lamination, local mud drapes, and root structures are present. Ripple lamination occurs internally within some large trough sets; the small structures are typically present in uppermost parts of the channel sequences. Lateral migration of point bars within river meanders is indicated in a few outcrops by large-scale accretionary bedding in the upper channel fill (fig. 12G).

Channel-fill facies have a grossly lenticular crosssectional geometry, but depth of basal scour and the extent of lateral accretion can vary considerably, resulting in a broad spectrum of channel shapes. Channel fills tend to fine upward, particularly in the upper parts (fig. 12F and G). However, a local variant, shown in figure $12 \mathrm{E}$, is a bipolar trend with coarser trough crossbedded sands at the base and one or more coarse avalanche sets capping the sequence. This latter sequence may be produced by migrating longitudinal bars (Jackson, 1976), spillover lobes (Bernard and others, 1970), or by chute bar accretion (McGowen and Garner, 1970). E-log patterns (fig. 6, log F) reflect both transitional and sharp upper boundary types.

Top stratum deposits consist of very fine sand, silt, and mudstone, which may be rooted, finety laminated, or structureless.

\section{Crevasse Splay Facies}

The crevasse splay facies consists of thin to thick, crudely bedded and lenticular sand and sandstone, siltstone, and mudstone deposited along the margins of the fluvial channels (fig. 12). Chita-Corrigan crevasse deposits resemble those of the Gueydan fluvial system in gross character but are quite different in detail. Chita-Corrigan crevasse facies are very well preserved and ubiquitous in areas of channel facies development and are readily differentiated into proximal and distal components on the basis of bed thickness, degree of channeling, abundance and preservation of sedimentary structures, and composition. Altered air fall ash is a dominant component of crevasse facies but is diluted by nonvolcanic silt and sand.

Crevasse splay facies form coalescing aprons that thin away from fluvial axes and interfinger with floodplain or lacustrine mudstone and siltstone (fig. 12). Widths of the apron are in the $10^{4}$ feet or meter range. Individual crevasse sequences rarely exceed $30 \mathrm{ft}(9 \mathrm{~m})$ in thickness, but stacking of channels and their associated crevasse splay units results in superimposed facies several hundred feet thick (fig. 6, $\log$ E). Individual beds or lenses within the crevasse sequence typically are a few feet thick, though proximal crevasse channel fills may be 10 to $20 \mathrm{ft}$ ( 3 to $6 \mathrm{~m})$ thick.
Proximal crevasse subfacies.-Deposits are characterized by a variety of structures, textures, and bedding features, which occur in close geographic and stratigraphic proximity. Lenticular crevasse channels range from a few feet to over twenty feet in thickness, and from a few feet to hundreds of feet in width (where lateral migration has occurred). Width/thickness ratios are moderate to low, and lenticularity and irregular basal scour are hallmarks of crevasse channels.

Proximal crevasse deposits contain abundant fine sand and silt, as well as local lenses of medium sand. Mud chip and mud clast conglomerate is diagnostic and mav comprise a volumetrically significant sediment type. Sands range from very muddy and cemented by intergrown cutanic coats of clay and dispersed silica (indicative of intensive soil formation) to clean and well sorted. Common accessory features include local zones of micrite nodules, scattered ferruginous nodules (commonly with pyrite cores), and carbonaceous or silicified wood and plant debris.

Ripple, climbing ripple, wavy, and parallel lamination, medium-scale trough cross-lamination, and dewatering structures are abundant and well developed (fig. 12B). Rooted zones, clay and mud drapes, and mud cracks are also common. Crevasse channel-fill units contain mediumto large-scale trough cross-stratification, planar lamination, multiple crosscutting scour surfaces, and dewatering and load structures on a larger scale (fig. 12D). Lateral accretion bedding was formed locally as crevasse channels migrated, producing large-scale foreset bedding. Muddy sands typically are highly rooted, irregularly bedded, vuggy to spongy, and display many pedogenic features suggesting periodic soil formation on the exposed crevasse surface.

Distal crevasse subfacies.-Deposits consist of areally extensive, thin to thick, irregular beds of moderately to highly indurated, siliceous, tuffaceous, muddy siltstone to fine sandstone; local lenses of poorly sorted medium sandstone also occur. Beds commonly display poorly defined internal lenticularity, blocky fracture (soil peds), and highly deformed, ovate internal structure suggesting gilgai formation (Gustavson, 1975). The base of beds is sharp, and load structures are common. Primary structures were almost entirely destroyed by root churning or shrink-swell pedogenic processes typical of highmontmoriflonite soils developed on ashy sediments. Cutanlined root tubules, spongy to vuggy textures, and claycoated fracture surfaces are ubiquitous. Filled mud cracks occur locally. Mud chips and pellets and ferruginous nodules are common accessory components.

Crevasse facies commonly form a progradational vertical sequence grading from massive floodplain mudstone 
and siltstone upward into interbedded floodplain and distal crevasse beds, capped in turn by lenticular or thick-bedded proximal crevasse units (fig. 12D). Proximal and distal crevasse deposits are commonly separated by local scour surfaces.

\section{Well-Drained Floodplain Facies}

Channel and crevasse facies of the Chita-Corrigan fluvial system are interbedded with floodplain tuffaceous mud, silt, and clay that are similar to floodplain facies of the Gueydan system. Calcareous and ferruginous nodules are common, and local gypsum veins occur. Root traces are common and spongy textures occur locally, but other paleosoil structures are subdued or absent.

Well-drained floodplain facies are best developed in the interchannel areas along the southwestern part of the system flanking the Washington and Montgomery county fluvial axes (fig. 6, $\log$ D). They grade vertically and laterally into distal crevasse deposits and overlie the top stratum of fluvial channel fills.

\section{Interchannel Lacustrine Facies}

Levee-bounded interchannel areas in the eastern part of the Chita-Corrigan fluvial system were infilled by distinctive lacustrine facies that contain common progradational crevasse splay sequences. Lateral dimensions of lacustrine units are quite variable; deposits are typically tens of feet thick and may form superimposed sequences several hundreds of feet thick (fig. 6, $\log$ G). Lacustrine deposits are bounded laterally and vertically by crevasse and channel facies and are commonly interbedded with well-drained floodbasin facies. The lacustrine facies is lithologically heterogeneous. The most distinctive lithology is a massive, olive to gray, bentonitic claystone exhibiting common slickensided fracture surfaces, presumably produced by subaqueous shrinkage of rapidly deposited montmorillonitic mud. Structureless lacustrine clays grade upward and laterally into thin to thick beds of tuffaceous mud, silt, and fine sand. Some of the best preserved ash beds in the Catahoula of East Texas (Fisher, 1965) are within the lacustrine facies. Locally, highly siliceous silt and mud units occur. Disseminated plant debris and large wood fragments are common, particularly in muddy and silty units; in fact, interchannel lacustrine facies are the most uniformly organic-rich facies in the Catahoula. Lacustrine deposits contain pyrite balls, crystallaria, and tubules and are typically diatomaceous (Fisher, 1965).

Sedimentary structures in silty to sandy lacustrine beds include interlaminated sand, siltstone and mudstone, abundant ripple, wavy, and parallel lamination, medium- to small-scale trough cross-stratification, local burrow zones, climbing ripple cross-lamination, clay drapes, dewatering and sediment flowage structures, mud cracks, rippled bedding surfaces (including symmetrical long crested ripples produced by oscillatory waves), and abundant small-scale root casts and molds.

Thin, but well-developed progradational sequences are a distinctive feature of the lacustrine facies. A complete sequence includes (1) massive, homogeneous claystone; (2) massive to crudely bedded mudstone containing fine root and burrow systems; (3) thick- to medium-bedded, highly root-disturbed silty mudstone to muddy sandstone, which grade laterally into local distributary channel-fill lenses of coarser sand containing well-preserved primary sedimentary structures (fig. 12, section $\mathrm{C}$ ). The entire sequence is capped by a paleosoil zone. An analogous interchannel lacustrine sequence has been described in great detail by Coleman (1966), and Fisk (1952) detailed the progradational history of a major lacustrine delta into Grand Lake, Louisiana.

\section{Paleosoils}

The Chita-Corrigan fluvial system is characterized by abundant, well-developed paleosoils which formed on subaerially exposed fluvial top stratum, crevasse splay, and lacustrine delta deposits. These soil zones display similar pedogenic features as Gueydan paleosoils discussed previously and are classed as vertisols. However, the increasing content of kaolinite in East Texas Catahoula muds, as well as other indicators of a more humid climate, suggests a tendency toward formation of andosols, which form in humid climates on volcanic ash (Fitz Patrick, 1971).

\section{Facies Associations and Distribution}

Figure 12 schematically illustrates the lateral association of major Catahoula facies. Channel-fill units are flanked by contemporaneous, proximal crevasse splay facies, which grade, in turn, into distal crevasse splay deposits. Crevasse units are interbedded with well-drained floodplain and interchannel lake-basin facies.

Vertical stacking of facies (fig. 7) allows discrimination of areas dominated by particular facies on the depositional systems map (fig. 6). Coastal lake facies dominate along the southern margin of the Chita-Corrigan fluvial system, especially in the upper Catahoula. Welldrained floodplain deposits surround the major fluvial axes in the western half of the system, but interchannel areas become increasingly lacustrine in the eastern half. Fluvial channel-fill and crevasse deposits are intimately interstratified and have not been differentiated on the facies 
map or on strike sections (figs. 6, 7). Crevasse splay sands are also common in interchannel floodplain and lacustrine areas. Chita-Corrigan fluvial facies grade basinward into Frio deltaic facies.

\section{Environmental Reconstruction}

Figure 13 reconstructs the depositional environments in which Chita-Corrigan facies were deposited. Using the criteria listed in table 1, fluvial channels appear to have been sinuous to meandering mixed load types. Lateral migration of channel meanders resulted in accretion of point bars along the margin of a relatively narrow, deep, low-water channel; during periods of high discharge, flow topped the point bars and locally modified the fining-up trend. Vertical sequences resemble those described in point bars of the Colorado and Amite Rivers (McGowen and Garner, 1970), Arkansas River (Reineck and Singh, 1975), Wabash River (Jackson, 1976), and Brazos River (Bernard and others, 1970).
Crevasse splays were exceptionally well developed along the margins of the leveed channels, where distributary channels funneled sediment through gaps in the levees onto the floodplain or into interchannel lake basins. Size of proximal crevasse channels, as well as the progradational nature of many crevasse sequences, indicates persistence of individual splays through multiple flood events. Splay and levee deposits form broad sand-rich wings on either flank of the channel fill, broadening resultant sand isolith patterns. Beyond the influence of crevassing, the floodplain aggraded by settling of suspended sediment from floodwaters. Interchannel lakes, which formed between the highstanding levees of the main river channels, infilled by aggradation of suspended mud and clay and by progradation of crevasse deltas (fig. 13).

Unlike the Gueydan fluvial system, the ChitaCorrigan system possessed multiple tributary drainages. Small rivers entered the coastal plain between the San Marcos arch and LaGrange (fig. 6, plates I and III). Three

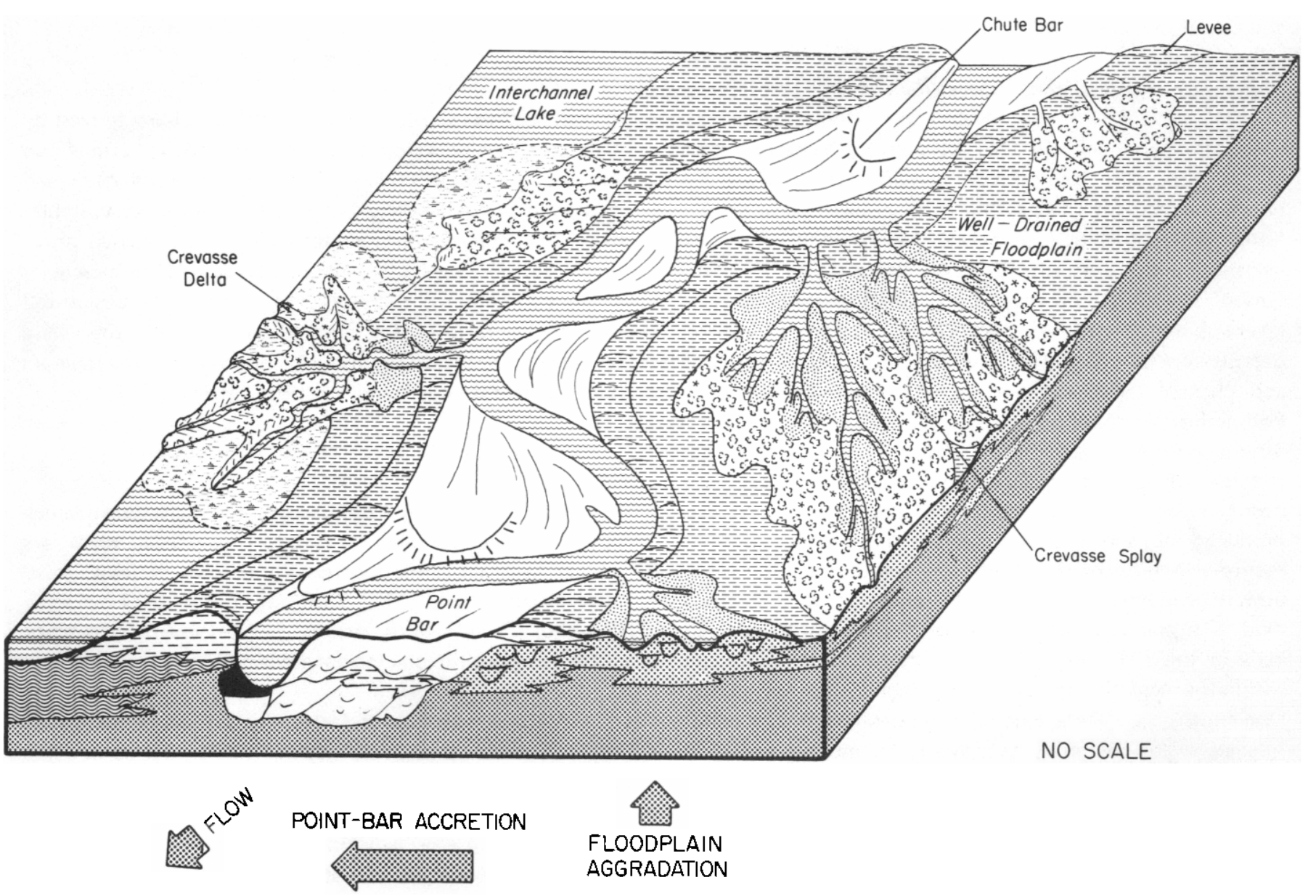

Figure 13. Schematic reconstruction of Chita-Corrigan depositional environments. Mixed load, sinuous to meandering streams and associated levees and crevasse splays formed relatively high, well-drained belts separated by floodplain and poorly drained interchannel lacustrine basins. Crevasse splays were well developed, abundant, and spread into floodplain and lake environments. 
large, permanent rivers discharged across the central part of the system; additional fluvial axes may be present in eastern Louisiana. Abundance of overbank crevasse deposits and internal heterogeneity of the fluvial channel fill indicate that the stream discharge was highly variable.

Climatic indicators include: (1) paleosoil structure and composition, (2) widespread distribution of abundant vegetation as indicated by root casts, and (3) distribution of interchannel lake deposits. The latter two factors suggest a subhumid to humid climate for the upper Texas Coastal Plain during deposition of the Chita-Corrigan fluvial system. Significant soil features include gilgai structures, which are typical of montmorillonitic soils in subhumid to humid climates with numerous wet-dry cycles (Gustavson, 1975), and abundant kaolinite in Catahoula mudstones of the northeastern part of the system (see section on Petrofacies). Hence, climatic gradients during Catahoula deposition paralleled modern gradients of the Texas coast.

The sporadic influx of large volumes of airborne ash also influenced deposition in the Chita-Corrigan system. Flooding increased, and overbank crevasse splay, lacustrine, and floodplain facies were highly tuffaceous. Fresh ash is rarely preserved, however. The abundance of montmorillonite and kaolinite, both of which can be alteration products of ash, and the virtual lack of detectable illite, which is common in pre-volcanic Eocene units of East Texas (according to data in Fisher, 1965), substantiate the hypothesis that reworked volcanic ash comprised most of the suspended load of Catahoula streams as far east as the Sabine River.

\section{PETROFACIES}

Compositional data on Catahoula sands and muds were compiled from the literature and supplemented with petrographic examination of an additional 46 samples and $x$-ray diffraction analysis of 20 samples to produce a regional description of sand and mud petrofacies. Results are summarized in figure 14. Standard point-count and $\mathrm{x}$-ray techniques were employed.

\section{SAND PETROFACIES}

Catahoula sands form two compositionally distinct groups:

1. Fine- to medium-grained sands of the Gueydan system consist of subequal mixtures of plagioclase feldspar, volcanic rock fragments, and quartz (McBride and others, 1968). These sands are classified as feldspathic litharenite and lithic arkose categories according to Folk's (1974) classification. Coarser sands contain increasing percentages of rock fragments; finer sands are proportionally richer in quartz and feldspar. Common accessories include abundant tuffaceous mud grains (not incorporated in the compositional plots because they were derived locally and reflect local depositional conditions rather than provenance), glass shards (counted as volcanic rock fragments), variable percentages of carbonate rock fragments (CRFs), heavy minerals, and up to 4-percent magnetite/ilmenite. Volcanic rock fragments are dominantly felsic to intermediate types. All compositional data for Gueydan sands are summarized on the left-hand triangular plot shown in figure 14. Samples from Starr, Webb, and Duval Counties cluster within a restricted field.

2. Fine- to medium-grained sands of the ChitaCorrigan system, in contrast, consist of quartz with subequal amounts of orthoclase, plagioclase, and rock fragments fincluding chert and some recognizable volcanic debris). Minor components include magnetite and traces of tourmaline and zircon. The average compositional range of Chita-Corrigan sands is shown on the summary triangular plot on the right side of figure 14. Sands of this suite include subarkoses, sublitharenites, lithic arkoses, and feldspathic litharenites. Coarser sands contain abundant grains of black chert and polycrystalline and vein quartz. Very fine sands and silts are quartz rich and micaceous. Carbonate rock fragments are present in subsurface samples but are leached from the outcrop.

The sample suite from Karnes County is a mixture of both the Gueydan and Chita-Corrigan suites (fig. 14). Compositional parameters suggest mixing of channel sequences from both fluvial systems; in fact such mixing can be recognized in single outcrops in eastern Karnes County. Volcanic-rich sands occur in or associated with the northeast-trending sand belt shown on plate I. Lighter colored, quartz-feldspar sands are found in local, thin sand units that probably entered the area from the north or northwest.

The distinct petrofacies in the Catahoula Formation further support differentiation of two principal fluvial systems. Distribution of abundant volcanic debris, which has a presumed source in Trans-Pecos Texas or northern Mexico (McBride and others, 1968), outlines the paleo-Rio Grande system (Belcher, 1975). Sands of the Chita-Corrigan system are more variable in composition and indicate a mixture of Central, North, and East Texas sources, probably combined with material from the lower midcontinent. Presence of carbonate rock fragments in south and central parts of the Catahoula shows that Cretaceous carbonate rocks were exposed in Central and West Texas. Sample control is inadequate to define more local petro- 


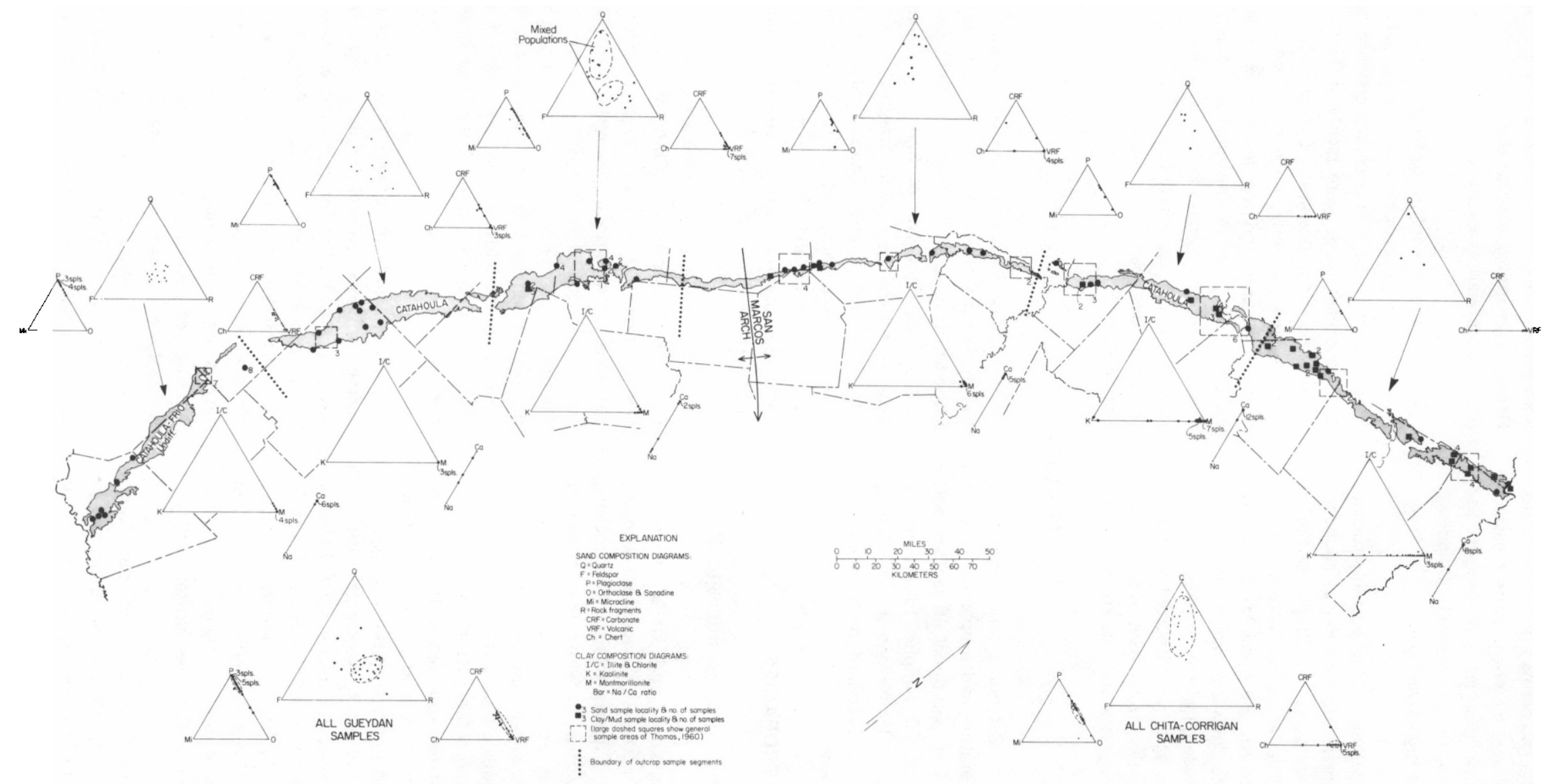

Figure 14. Petrofacies summary of the Catahoula Formation. The upper tier of triangles shows the geographic mineralogical variation of fine to medium sand and sandstone. Compositional data for all sand samples from each depositional system are grouped in the large triangles for comparison. Dashed ovals show compositional averages for each system. Samples from Karnes County fall in both average fields, suggesting mixing of drainage systems, along the southern flank of the San Marcos arch. The lower tier of triangles shows the geographic variation in clay mineralogy of Catahoula muds. Note appearance of kaolinite in the eastern part of the Chita-Corrigan fluvial system. (Includes data compiled from MeBride and others, 1968; Thomas, 1960; McCracken, 1967) 
facies, particularly within the Chita-Corrigan system where isolith maps and facies reconstruction indicate several areally distinct fluvial bel ts.

\section{CLAY PETROFACIES}

Clay mineral composition in the Catahoula Formation shows a gradation from a mixed calcium-sodium montmorillonite suite in the southern and central coastal plain to a mixed montmorillonite-kaolinite (allophane?) suite in the northeastern coastal plain (fig. 14). Unlike sand petrofacies, bulk clay mineral content is independent of the depositional systems boundary.

Significantly, both montmorillonite and kaolinite (allophane?) are likely alteration products of volcanic ash (Fitz Patrick, 1971; Hay, 1959). Allophane and kaolinite formation are enhanced by an acidic environment rich in humic acids. Consequently, a more humid climate and attendant increase in vegetation, especially in interchannel floodbasin and lacustrine areas, would favor formation of kaolinite minerals. Maximum kaolinite content occurs in interchannel lacustrine units of the Chita-Corrigan fluvial system. Furthermore, the general absence of detectable amounts of detrital illite, chlorite, or their mixed layer variants, which are common components of clays of the probable source areas (Walton, 1968), suggests that clays and muds in the Catahoula were derived primarily from the breakdown of airborne volcanic ash, rather than from reworking of older Tertiary, Cretaceous, or Paleozoic strata. Absence of detectable detrital illite and chlorite (within detection limits of the $x$-ray method) compared with an average content of 10- to 20-percent illite plus chlorite for older Tertiary muds indicates that ash-derived clays significantly exceed detrital clays in both the Chita-Corrigan and

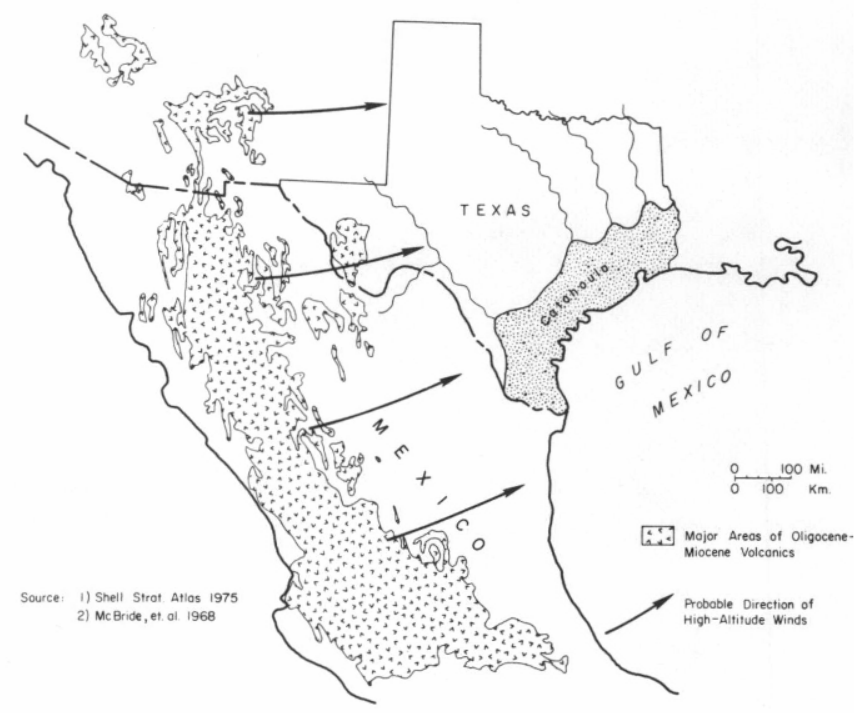

Figure 15. Areas of Oligocene volcanism and probable high-altitude wind patterns. Airborne material deposited in the Catahoula was derived from northwest Mexico and deposited in the coastal plain or along lower reaches of the major extant drainage basins.

Gueydan fluvial systems. It follows that both systems contain great volumes of volcanic debris that could serve as a source of uranium.

Source of the volcanic debris was most likely the extensive Oligocene-Miocene volcanic fields of northwest Mexico (fig. 15). By analogy with present meteoric circulation patterns, mid-Tertiary high-altitude winds probably blew from the west and southwest (McBride and others, 1968) and would have transported debris from explosive eruptions eastward to the Texas Coastal Plain and to drainage basins of the Catahoula rivers.

\section{STRUCTURAL DEVELOPMENT}

The Texas Gulf Tertiary basin is an area of passive tectonics dominated by tensional, coast-parallel fault trends and diapiric structures (Murray, 1960). Where not influenced by faulting or diapirism, beds dip gently gulfward.

History of growth-fault development is directly related to depositional history (Fisher, 1973; Jones and Wallace, 1974; Dailly, 1976) and may be summarized as follows (fig. 16):

1. Deposition of thick slope and prodelta mud sequences.

2. Loading of the thick, undercompacted muds by a prograding deltaic system.

3. Initiation of down-to-the-coast syndepositional faults along the delta margin and upper slope in combination with mobilization of thick masses of the deep, overpressured mud or of salt.
4. Accentuation of fault displacement and deposition of delta margin facies on the downthrown side of faults.

5. Progradation of the delta system beyond the fault zone and activation of younger, basinward fault zones.

6. Decreasing activity along the fault zone as successive delta plain and fluvial systems override the buried delta platform. Catahoula fluvial systems are affected primarily by this final phase of decreasing fault activity.

Growth faults are characteristically arcuate in plan view and concave toward the coast, dip at approximately 45 degrees at shallow to intermediate depths, grade into bedding plane faults where they toe out in deeply buried muds, and have associated antithetic faults (Carver, 1968; Bruce, 1972). Because growth fault zones persist vertically, major growth fault zones initiated by progradation of 

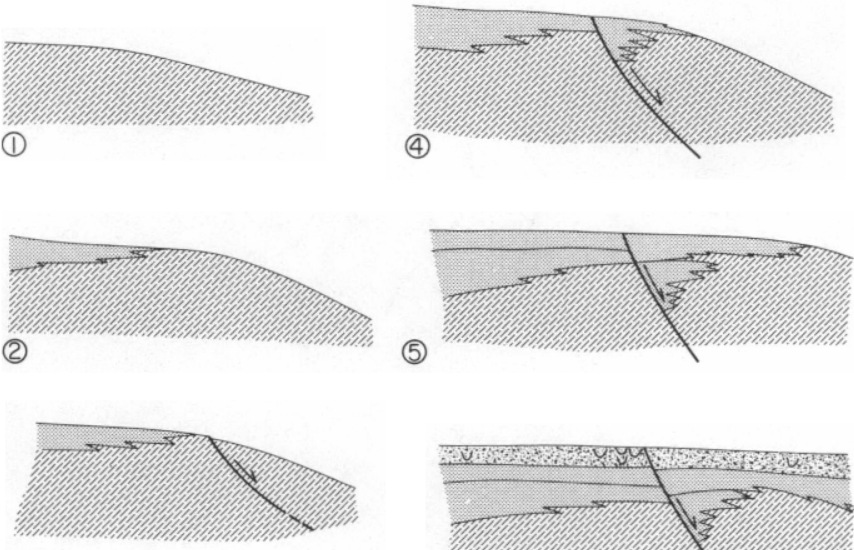

(3)

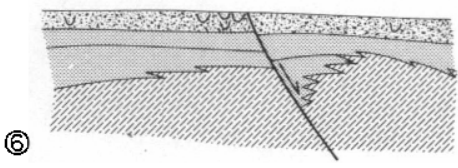

Diogrommatic

Fluvial Facies

Deltoic Focies

Prodelto/Slope Focies

Figure 16. Summary history of a growth fault zone in the lower Tertiary Gulf coast basin. (1) Deposition of thick mud section. (2) Delta progradation and sediment loading. (3) Fault initiation. (4) Deposition of delta margin facies on downthrown side. (5) Renewed basinward progradation of delta system. (6) Waning activity along fault zone.

underlying Wilcox, Yegua-Jackson, and Vicksburg depositional systems later affected the Gueydan, and to a lesser extent, the Chita-Corrigan fluvial systems. Areal association of some Gulf coast uranium deposits with fault zones accentuates the importance of these structural elements.

\section{FAULT DISTRIBUTION}

Plate IV is a compilation of known major faults within or stratigraphically below the Catahoula Formation. (Projections of faulting to a Catahoula datum assuming 45-degree dip result in inconsequential lateral displacement at this map scale.) Fault locations were compiled primarily from commercial maps (with permission of Geomap Company), with additional faults taken from Tucker (1967) and the Geologic Atlas of Texas (V. E. Barnes, project director). Because growth fault displacement tends to die out upward, the map, which shows faults located variously at Wilcox, Jackson, and Catahoula levels, represents a more complex distribution than likely present at shallow Catahoula level.

Several prominent fault zones occur in South Texas; however, near-surface or shallow subsurface growth faults are virtually absent in northeast Texas (plate IV). Displace- ment along faults rarely exceeds a few hundred feet and is typically much less within the Catahoula. Regional dip sections indicate some local thickening of the Catahoula section across major faults, and flattening or reversal of regional dip on the landward side of fault zones is common (see fig. 2, wells $Q-11$ to $Q-252$, section $\left(0-O^{\prime}\right)$ ).

\section{EFFECT ON SEDIMENTATION}

Growth faulting directly affected sediment distribution within the Catahoula. Comparative examination of sand isolith maps (plates I and II) and the fault distribution map (plate IV) shows that areas of well-developed growth fault zones are characterized by complex sand distribution patterns, which assume an almost reticulate pattern of dipand strike-oriented segments. Particularly good examples occur in Duval County. In contrast, sand patterns are dominantly dip oriented in areas such as Walker and Montgomery Counties where subjacent growth faults are absent.

A detailed sand isolith map in a small area in Duval County illustrates the interrelationship between facies and fault trends (fig. 17). Dip-oriented fluvial channel-fill sand belts show anomalous thickening and right-angle deflection where they intersect subjacent faults, which were mapped on an upper Jackson datum. Cross sections along fluvial axes (fig. 18) show a disruption of correlative sand units where faults are crossed, even though fault displacements within the Catahoula section are at most a few tens of feet. Such disruption of the trend and vertical distribution of channel-fill sand facies will certainly affect postdepositional ground-water flow within the Gueydan system.

Analogous interrelationships between modern drainage patterns and sand distribution within shallow Pleistocene fluvial sand bodies have been noted by Kreitler (1976 and personal communication) in the lower Texas Coastal Plain near Houston. Coastal plain fluvial systems, such as the Gueydan and Chita-Corrigan, appear to be highly sensitive to near-surface zones of structural weakness and slight topographic variations produced by deep-seated growth faults.

\section{POST-DEPOSITIONAL EFFECTS}

Siliceous and carbonate-rich knobs, which form small rounded hills, are conspicuous features of the Catahoula outcrop belt from Live Oak to Webb Counties (plate IV). The knobs are areally and genetically associated with surface or near-surface fault zones and occur in strikeparallel trends (Freeman, 1968). Hypotheses for their origin range from mud volcanoes and diapirs (Freeman, 1968) to 


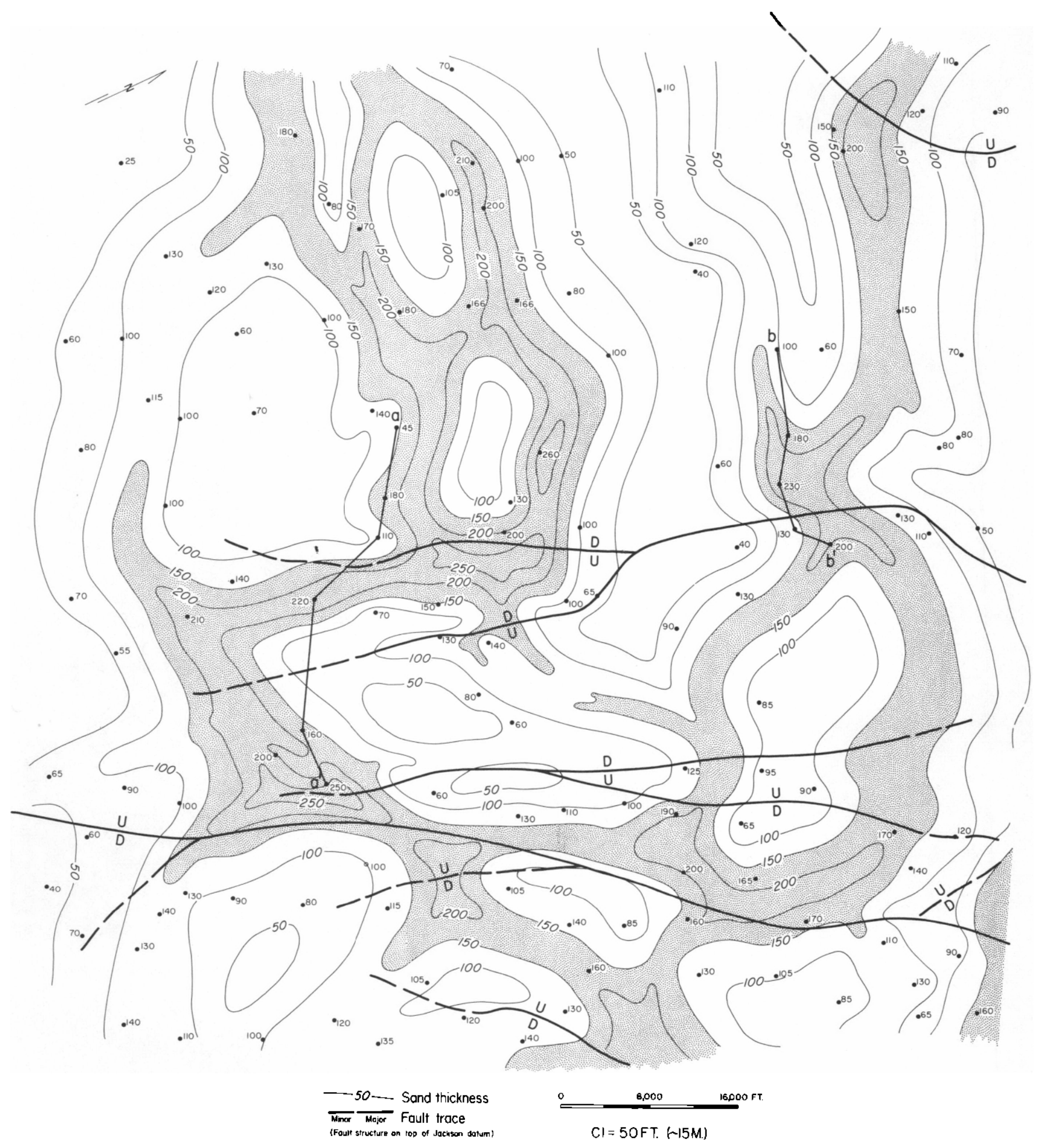

Figure 17. Isolith map of middle Gueydan sand showing effect of associated faults on geometry and trend of fluvial sand bodies. Location of map area shown on plate I. Fault traces on top of Jackson datum approximately $\mathbf{3 0 0}$ feet below base of the mapped interval. 
28

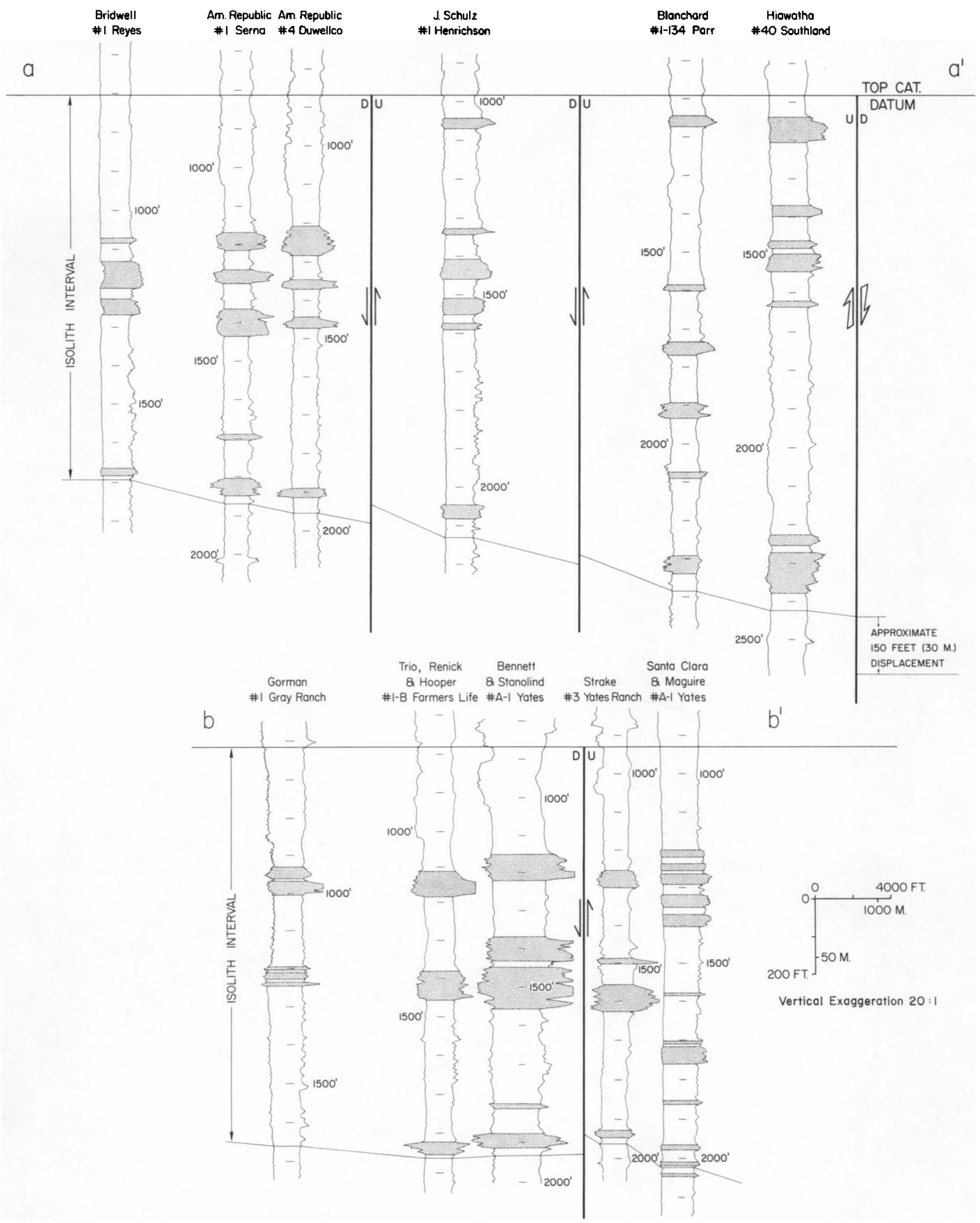

Figure 18. Cross sections showing abrupt changes in stratigraphic position of sand bodies across faults. Modification of sand body geometry appears disproportionate to the small displacement of most of the faults and illustrates the extreme sensitivity of coastal plain drainage networks to subtle structural features. Location of sections shown on figure 17. 
upward-migrating solutions along fault zones (Bailey, 1926). Silica-carbonate knobs locally contain anomalously high uranium.

Thin, vertical clay dikes are prominent in Catahoula deposits as far north as Polk County. Detailed mapping by McBride and others (1968) showed that clay dikes are concentrated along fault zones and that directional trends of the dikes parallel the strike-oriented faults. Dikes range in size from a few feet to at least one hundred feet $(30 \mathrm{~m})$ in vertical extent (larger dikes penetrate the entire section exposed in uranium pits). The dikes are injection features produced by loading of water-saturated, montmorillonite muds. Early formation of dikes is indicated by their local effect on root density within some of the channel-fill deposits. Consistent strike-oriented trend of the dikes reflects on a small scale the tensional stress regime of the coastal plain. Significantly, similar clay dikes locally control the distribution of uranium ore mineralization in the Jackson Group (R. A. Brooks, personal communication).

The abundance of clastic diapiric features in the Catahoula reflects the sporadic high depositional rates within a stressed fluvial system that was periodically blanketed by easily eroded airborne volcanic ash.

\section{SUMMARY COMPARISON OF CATAHOULA AND OUATERNARY GULF COASTAL PLAIN DEPOSITIONAL PATTERNS}

Depositional patterns of the Catahoula Formation, based on environmental reconstruction and sand petrofacies, are summarized graphically in figure 19. For comparison, Quaternary depositional patterns of the Texas Coastal Plain are shown on the right side of the figure. The similarities are remarkable:

1. Catahoula and Quaternary drainage patterns are very similar. A major river that originated in the desert southwest drained into the Rio Grande embayment.

2. Small, intrabasinal streams, draining the margin of the Gulf coast basin and Central Texas, occupied the south-central Coastal Plain during both Catahoula and Quaternary deposition.

3. Two large rivers entered the Chita-Corrigan fluvial system at the approximate location of the Quaternary Colorado-Brazos Rivers. Size of the paleochannels suggests that they too were extrabasinal systems that drained large areas beyond the margin of the Coastal Plain.

4. A large, but less well-defined river or rivers flowed across the upper Texas Coastal Plain where similarly large, dominantly intrabasinal streams, such as the Sabine and Trinity, flowed throughout the Quaternary.

5. Although outcrop patterns during Catahoula deposition differed from the modern outcrop patterns, which are shown for comparison, composition of the channel-fill sands indicates that principal source materials and their areas of exposure were similar.

6. Oligocene and Quaternary climatic trends along the Coastal Plain are similar. Further, Catahoula paleoclimates appear to have resembled modern climates of the same geographic area.

Deep-seated growth faults, although not shown on the map, have influenced river trends and consequent depositional patterns of Quaternary systems in the same way structural trends affected Catahoula fluvial systems.

The principal difference between Quaternary and Oligocene depositional regimes was the influx of airborne ash into the drainage and depositional basins that choked Catahoula fluvial systems with fine sediment and produced mineralogically homogeneous soils and unusually abundant crevasse splay deposits. Basic drainage patterns established in the early Tertiary have persisted and played a recurrent depositional theme in the Tertiary Gulf coast basin (Fisher, 1969; Guevara and Garcia, 1972).

\section{POST-DEPOSITIONAL HISTORY}

Definition and mapping of depositional systems and their component facies, lithic composition, and structural features provide the framework for analysis of the postdepositional events that affect the Catahoula Formation. The distribution of ash (the presumed source of the uranium), the spatial arrangement of the permeable facies that can pass large volumes of ground water (which transports uranium), the structural discontinuities that could disturb the flow field, and the composition of the strata through which the waters circulate must be defined before post-depositional events, including uranium mineralization, can be interpreted.

\section{GROUND-WATER FLOW HISTORY}

Because uranium is believed to be transported by migrating ground waters (Hostetler and Garrels, 1962), understanding of the evolving flow system in the Catahoula 


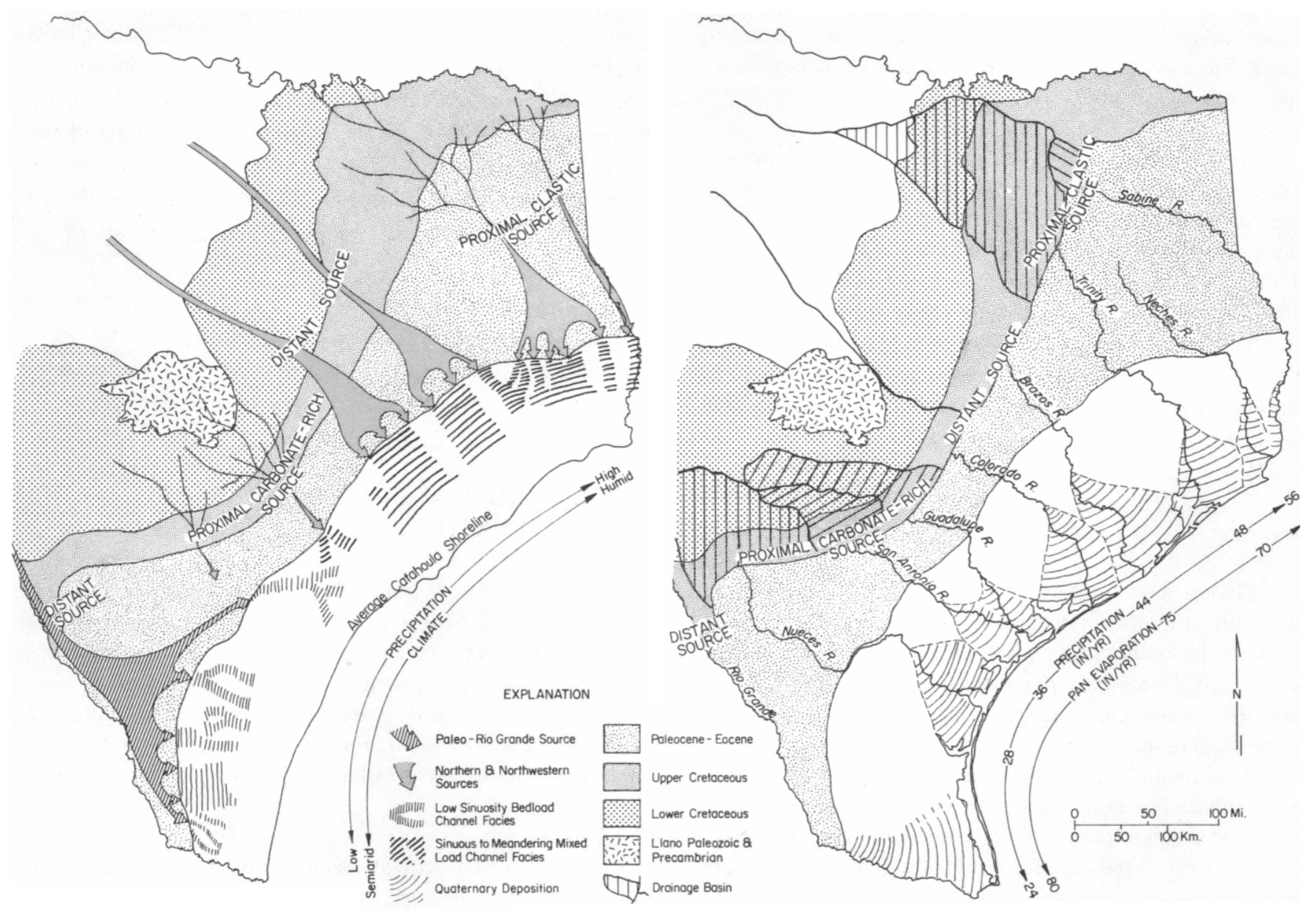

Figure 19. Comparison of Catahoula (Oligocene) and Quaternary coastal plain geomorphology, depositional patterns, and climatic zonation. The Holocene outcrop belt is superimposed on both illustrations for comparative purposes. Boundaries between differing outcrop belts have undoubtedly evolved through the Tertiary, but similar source lithologic suites have persisted since initiation of Catahoula deposition.

Formation since its deposition is a prerequisite for determination of the significant parameters controlling uranium distribution (Hagmaier, 1971).

\section{Factors Determining Ground-Water Flux}

The flux of ground water through a volume of sediment is controlled by a number of factors. Flow volume is directly proportional to the head loss resulting from the flow and inversely proportional to the length of the flow path. Introduction of a constant, called $K$, the coefficient of permeability, allows this statement to be written as the familiar Darcy equation

$$
Q=K A I
$$

where $Q$ is the volume of fluid transmitted, $A$ is the cross-sectional area through which the flow occurs, and $I$ is the hydraulic gradient. $\mathrm{K}$ is commonly measured in meinzer units by hydrogeologists. The meinzer unit is defined as the flow in gallons per day across a cross-sectional area of 1 square foot under a hydraulic gradient of 1 at $60^{\circ} \mathrm{F}$. Measurement of $\mathrm{K}$ in $\mathrm{ft} / \mathrm{day}$ is also common.

The coefficient of permeability can be measured on disturbed samples in the laboratory or by well tests in the field. By either method, permeabilities in typical sediments vary widely, ranging from $10^{-5}$ meinzers for compacted clays to $10^{5}$ meinzers for well-sorted gravels. Permeability is particularly dependent on grain size and sorting of the sediment (Masch and Denny, 1966). Significantly, permeability can vary by up to two orders of magnitude within sands of different grain sizes. Consequently, total sand content or percentage provides only an approximation of average permeability of a stratigraphic interval if significant variation in average grain size occurs.

Average permeability of the sedimentary sequence is, in turn, a primary control on the flux of ground water and 
is an internal property of the depositional system. However, permeability is an index of possible flow only; other variables determine the hydraulic gradient and thus actual flux.

Orientation of permeable elements will also affect ground-water flux. Highiy permeable conduits that trend down regional hydrodynamic gradient will effectively transmit more water into the subsurface than will permeable elements oriented at a high angle to the regional gradient (Payne, 1968, 1975). Orientation of the permeable elements is also an intrinsic attribute of individual depositional systems.

Finally, hydrodynamic boundaries may act as extrinsic limits for flow through a permeable system. The rate of recharge into an aquifer is determined by a number of variables including slope of the shallow water table relative to the regional hydrodynamic gradient (Freeze, 1969a), permeability of the overlying unsaturated material, and climate. In a coastal plain setting, water entering at the outcrop and moving downdip must ultimately move upward across bedding or along faults and be discharged to the water table. Thus cross-stratal permeability may become a major limiting factor if individual permeable members are isolated by very low permeability muds or clays and if structural discontinuities do not provide conduits for vertical flow.

\section{Terrigenous Coastal Plain Flow System}

The ground-water flow system is an open processresponse system; unlike an ancient depositional system. however, it is dynamic rather than static. That is, a ground-water flow system is subject to change throughout its existence in response to changes in external variables. Basic concepts of regional flow systems have been reviewed by Toth (1962) and Freeze (1969b).

The coastal plain is a one-sided geomorphic basin with regional slope in the coastward direction. The ground water table, which reflects topographic trends (Toth, 1962), also dips coastward, thus establishing a regional coastward hydrodynamic gradient that is transmitted to all serniconfined aquifers (Freeze, 1969b). Combination of the theoretical models of Freeze with data contained in reports of the Texas Water Development Board, Jones (1968), and Payne (1968) produces the coastal plain ground-water flow system schematically illustrated in figure 20 . The flow system consists of three parts:

1. Meteoric water recharges the aquifer where flow lines trend downward across the water table and enter the aquifer.

2. Water moves down gradient toward the coast within the aquifers. In this simple example, the lateral distance traveled increases with the depth of the aquifer.

3. Near the coast, in the area dominated by bay, lagoon, and marsh environments, ground water discharges

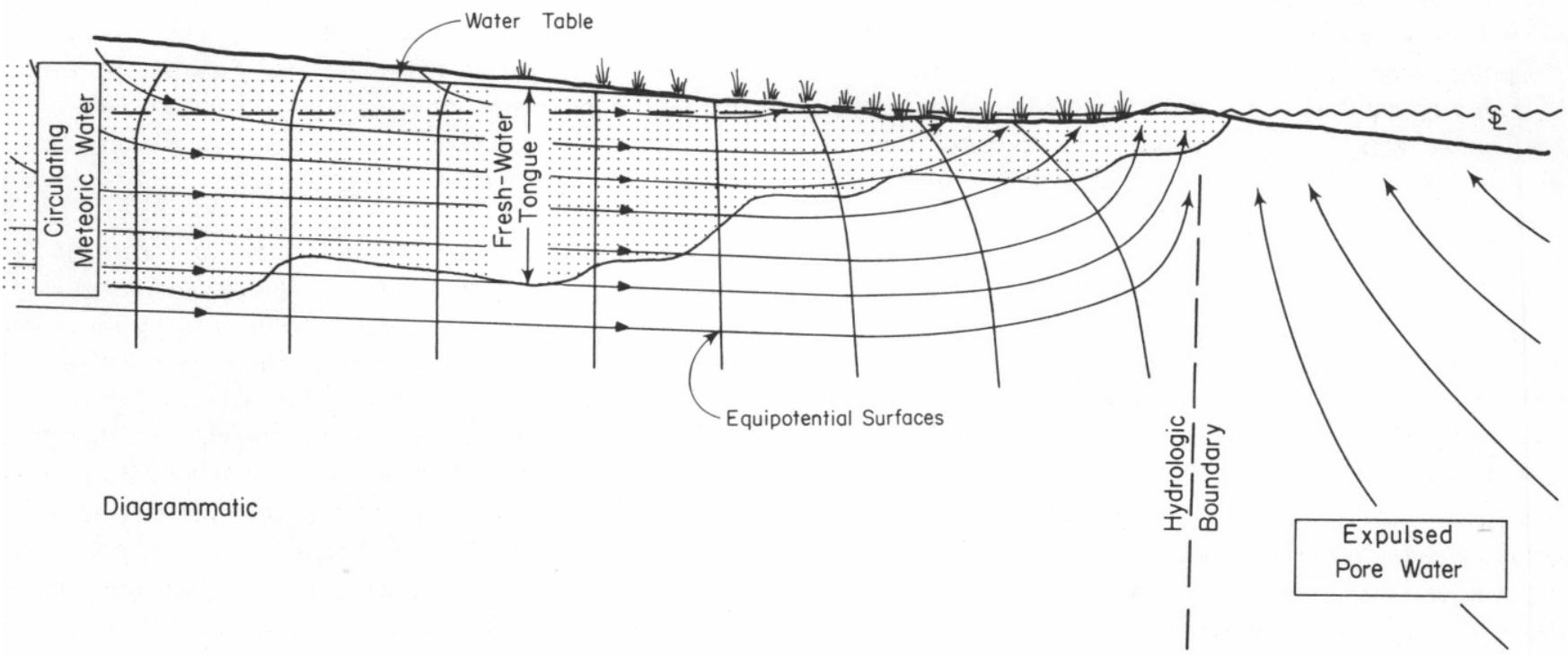

Figure 20. Simplified regional pattern of ground-water flow in a terrigenous coastal plain setting. 
to the surface by moving upward across stratigraphic boundaries and ultimately into water-table aquifers.

The coastline forms a hydrologic boundary separating basinward-circulating meteoric ground waters from discharging expulsed pore waters derived from compaction of deeply buried muds (Jones, 1968). A tongue of fresh water forms in the shallow aquifers and climbs section downdip as circulating waters equilibrate with soluble minerals in the aquifer and increase their dissolved solids content. Dissolved solids content could also be increased by vertical discharge of deeply buried saline waters into shallow, circulating aquifers.

Faults and shallow fracture zones associated with deep-seated growth faults complicate the flow field. Surface faults and photolinears in the Houston area compartmentalize shallow aquifers (Kreitler, personal communication). Discharge along fault zones is recorded by the chalcedonycarbonate knobs along the Catahoula outcrop in South Texas and is uniquely indicated by the presence of oolitic coats on sand grains in a fluvial channel-fill sequence penetrated by drilling in Karnes County. In the latter example, carbonate-saturated ground waters presumably discharged into the Catahoula stream along the FashingFalls City fault trend, which lay slightly up paleosiope, locally supersaturating the surface waters. A similar phenomenon along the Balcones fault zone near San Antonio is described by McGannon (1975).

In deeply buried aquifers, vertical infiltration through intervening aquitards (low permeability units that restrict the flow of ground water) becomes a significant factor of the ground-water flow system. Such leakage occurs where the potentiometric surface of the deep aquifer exceeds that of overlying aquifers and is most likely to occur in deeper fresh-water areas near the limit of fresh-water tongues (Payne, 1968). Presumably vertical leakage is enhanced by associated faulting.

\section{Modern Catahoula Flow System}

The modern Catahoula flow system can be deduced by analysis of a map showing the regional distribution of fresh-water-bearing sands (based on electrical log response) within the formation (fig. 21). The downdip extent of fresh-water lobes provides an index of the relative flux of ground water within various parts of the formation; areas of high ground-water flux are characterized by extensive downdip tongues of fresh water.

Mappable geologic parameters that may affect the recharge, downdip flow, or discharge of ground water include: (1) sand distribution, which is a basic control of permeability, (2) sand body orientation, (3) the distribution of subjacent fault zones, which determines the areas of possible vertical discharge, (4) the distribution of clay-rich lacustrine facies, which likely possess extremely low vertical permeability and would severely retard vertical seepage discharge, and (5) areas of topographic reversal or valley incision (where the land surface slopes away from the coast) that may deflect or pirate shallow recharge from the Catahoula aquifer. The relative significance of each of these factors in determining the local flux of fresh water in the Catahoula is graphically illustrated by figure 21 .

The primary control of ground-water flux is the distribution and orientation of permeable sand be/ts. Extensive downdip tongues of fresh water (such as in areas marked 1 on figure 21) center around major dip-oriented sand belts. In contrast, equally thick sand sections that are oriented subparallel to strike, and thus at a high angle to the regional potentiometric surface, produce updip salients of saline water (fig. 21, area 2).

The downdip extent and configuration of fresh-water flushing are closely related to the trend and position of fault zones. Tongues of fresh water typically thin or pinch out at or immediately updip of mapped fault zones (fig. 21, area 3). The relationship to faulting is further illustrated in figure 22, a dip section across a fault zone showing the steplike climb of the base of fresh water in the section as successive faults are intersected. The downdip fault, which has the largest throw, appears to act more as a hydrodynamic barrier on this section than as a vertical conduit. Catahoula sands at least two miles updip from the fault are charged with saline water, indicating deflection of flow lines vertically updip from the fault. The streamlines schematically illustrate the interpreted flow pattern across this fault zone; waters diverted upward from the Catahoula Formation mix with waters in the overlying Fleming sands and continue coastward.

Extent of downdip flushing may be controlled by limitations on regional upward discharge. Well-developed, thick, dip-oriented sand bodies with a high measured coefficient of permeability occur in the eastern half of the lower Catahoula Chita-Corrigan fluvial system, but the downdip extent of fresh water is considerably less than that in similar facies elsewhere in the remainder of the system (fig. 21). This area of limited fresh water corresponds with the area of maximum development of the clay-rich interchannel lacustrine facies, which is also best developed in the lower part of the Chita-Corrigan system. Apparently, the lacustrine facies contains very low permeability confining beds that severely restrict vertical discharge, and thus act as a primary control on ground-water flux in this part of the 

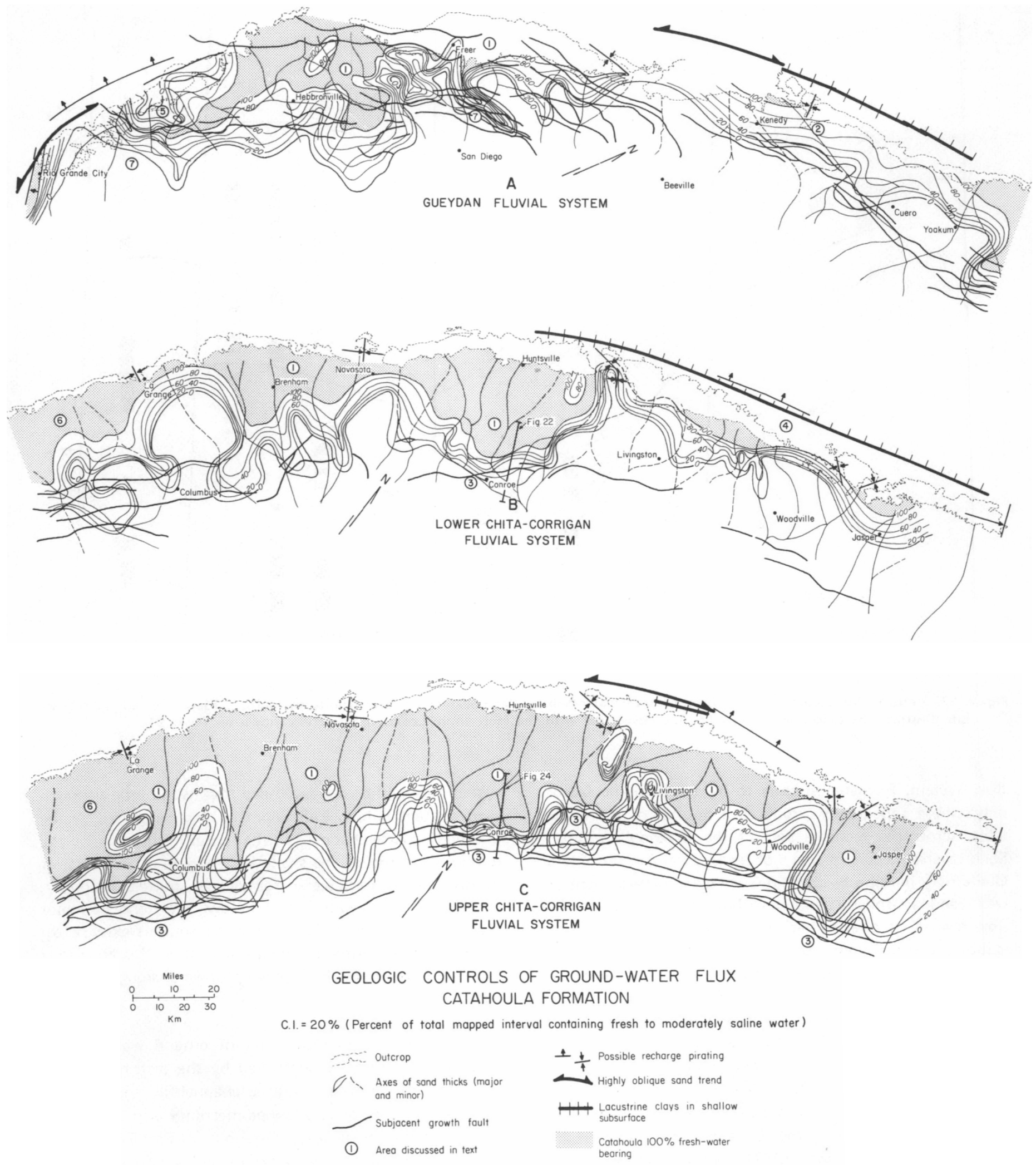

Figure 21. Distribution of fresh to slightly saline water in the Catahoula. Increasing flux of ground water results in deeper penetration of fresh-water lobes, thus the map provides a generalized overview of ground-water flow patterns. Geologic parameters that control flow include facies distribution, growth fault zones, and outerop topography. Numbered areas are discussed in text. 


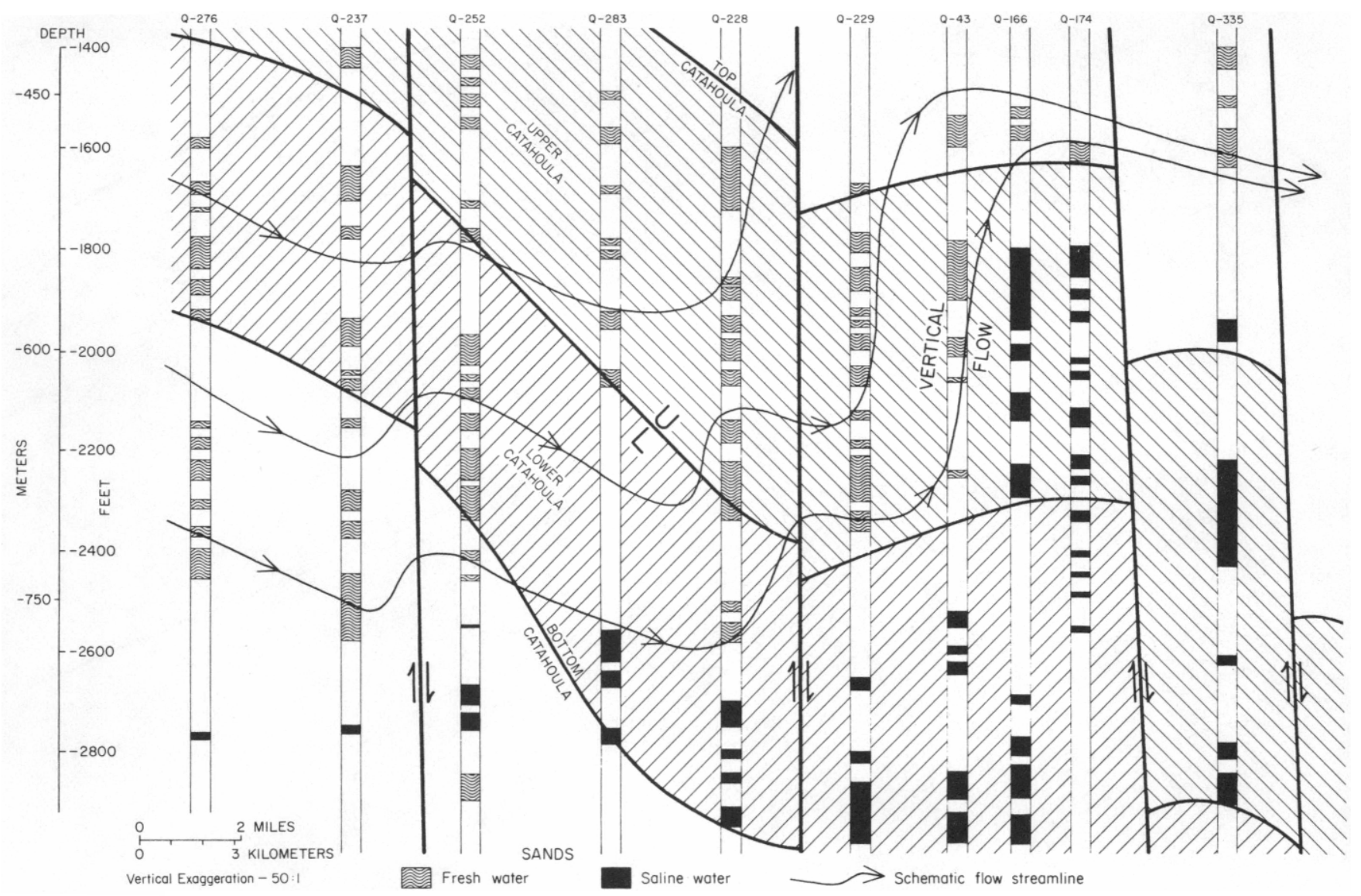

Figure 22. Vertical displacement of the base of fresh-water-bearing Catahoula sands in proximity to faulting. Flow lines are schernatic, but illustrate the extensive cross-stratal flow associated with the fault zone. Location of section shown on figure 21.

flow system. Recharge appears to be a controlling factor only where topography produces a reversal of the water table across the recharge belt of the Catahoula aquifer. Such reversal occurs in area 5 of figure 21 as a result of late Quaternary incision by the Rio Grande and development of west- and southwest-trending tributaries. Results of the flow reversal or pirating here are dramatic because the area exhibits the maximum development of Gueydan fluvial sands and should contain an extensive tongue of freshened water. The presence of apparent fresh to moderately saline water in the deeper subsurface may reflect $\mathrm{H}_{2} \mathrm{~S}$ or sulfate enrichment by vertical seepage along the fault zones. Smaller areas of possible recharge pirating occur where other rivers cross the Catahoula outcrop; however, none seem to affect the downdip flux of ground water. The inherent dispersion of flow in a heterogeneous media (Skibitzke and Robinson, 1963) may smooth over such minor irregularities in recharge.

Two areas appear anomalous on figure 21. Area 6, which lies at the southern edge of the Chita-Corrigan fluvial system, displays a well-developed fresh-water lobe although sand content is low. This anomaly may be caused by the unusually coarse channel fills that occur in this area, by the locally steep dip of the shallow Catahoula of this area, or by discharge of fresh water from deeper aquifers. Secondly, an arcuate "fresh-water" trail follows the trend of major fault zones in area 7. No fresh-water aquifers exist below the Catahoula Formation in this area; thus, this zone may indicate flushing by $\mathrm{H}_{2} \mathrm{~S}$ moving upward along the fault zone.

In summary, relative flux of ground water in the Catahoula is primarily controlled by the distribution and geometry of permeable fluvial channel-fill and crevasse facies. Occurrence of very low permeability lacustrine facies diminishes flux in the lower Catahoula of East Texas. Fault zones control the downdip extent and local geometry of flow by forming vertical conduits or hydrodynamic boundaries that force vertical flow. Knowledge of threedimensional facies distribution and location of structural trends allows accurate prediction of relative ground-water 
flux in over 80 percent of the Catahoula Formation. Deletion of geologically young recharge pirating in South Texas, which is caused by Pleistocene incision of stream valleys, would increase predictive success to approximately 90 percent.

\section{Historical Development of the Catahoula Flow System}

Examination of modern flow patterns in the Catahoula Formation is useful for expanding our understanding of the relative importance of various geologic factors in determining local ground-water flux, but modern flow represents only one phase in the history of the Catahoula aquifer system. As pointed out, flow is locally controlled by young geologic events. It has been hypothesized that periods of uranium mobilization have occurred during much of the time since Catahoula deposition (Weeks and Eargle, 1963; Eargle and others, 1975). Consequently, reconstruction of the evolving flow pattern is necessary to evaluate uranium potential of untested parts of the Catahoula and may also place limits on the actual time of mineralization.

Theoretical flow models of Freeze (1969b) combined with data in Texas Water Development Board reports on various aquifer systems in the Texas Coastal Plain indicate four significantly different phases in the evolution of a coastal plain aquifer such as the Catahoula Formation.

Syndepositional phase (fig. 23A).-Ground-water circulation is directly controlled by the water table, which experiences considerable fluctuation in response to seasonal or erratic climatic variation and defines a complex surface related to the positions of fluvial channels and interchannel divides. Consequently, flow cells are typically localized, variable, and geologically speaking, ephemeral (fig. 23A). Permeability of framework and nonframework facies is at a maximum.

Post-depositional phase (fig. 23B).-Ground-water circulation is semiconfined by deposition of low permeability units (floodplain, distal crevasse, and lacustrine facies) above permeable framework sands. Depths of burial are shallow (tens or a few hundreds of feet or meters), permeabilities of both framework and nonframework facies are still quite high, and recharge is primarily by downward flow of water through overlying less permeable beds. Refraction of flow into buried high permeability units produces, for the first time, a well-integrated flow system responding to the basinal hydrodynamic gradient (Freeze, 1969b). By analogy with the lower Texas Coastal Plain, fault zones influence flow patterns during this phase.

Burial phase (fig. 23C).-With greater depths of burial of the aquifer, flow is increasingly confined by overlying aquitards, recharge becomes more closely tied to the outcrop area of the aquifer, and permeability of the aquifer is decreased by compaction and diagenesis. Faulting affects flow patterns and assumes increasing importance in the cross-stratal discharge of water from the aquifer. Flow patterns are regionally coherent, but increasing confinement and decreasing permeability of the aquifer tend to decrease total flux; increased dip and consequent higher potentiometric gradient may partially or wholly counteract this decrease, however. Three subdivisions of the flow system may develop within the aquifer (fig. $23 \mathrm{C}$ ):

1. Circulating meteoric ground water dominates the updip portion of the aquifer.

2. Areas of stagnant conditions or of very low flux form in portions of the aquifer that lie downdip from zones of vertical discharge or that are otherwise isolated by faulting or diagenetically induced permeability barriers.

3. At greater depths, expulsed pore waters discharging toward the surface may enter shallow aquifers.

Exhumation phase (fig. 23D).-Erosion of the updip limits of Coastal Plain aquifers begins during the burial phase, but exhumation by drainage incision during the Quaternary has enhanced this destructional aspect of aquifer history. The results, which include local pirating of recharge, rejuvenated shallow meteoric circulation, and additional erosional destruction of updip portions of the aquifer, warrant distinction as a separate phase in the flow system history. Such a destructional phase can assume considerable significance in tectonically active depositional basins.

Both Catahoula fluvial systems have passed through the first two phases of their flow history, and modern flow is the product of some exhumation phase events superimposed on what primarily remains a burial phase system. The early post-depositional phase began with deposition of younger Catahoula fluvial facies on older Catahoula fluvial deposits and probably persisted during deposition of the overlying Oakville-lower Fleming Formations. High permeabilities and optimal vertical interconnection of permeable elements likely resulted in extensive downdip flushing during this phase. Concomittant recharge and discharge controls of ground-water flux, which are important to the modern flow picture (fig. 21), were less significant. Consequently, maximum control of flow geometry by sedimentary facies and growth faulting characterized this phase of Catahoula ground-water flow. As the Catahoula evolved from the early post-depositional to the burial flow phase, discharge limitations began to exert an increasing control on flux through part of the Chita-Corrigan fluvial system, and fault zones assumed increasing importance in localizing discharge. Recharge control of ground-water flux is a relatively young phenomenon. 

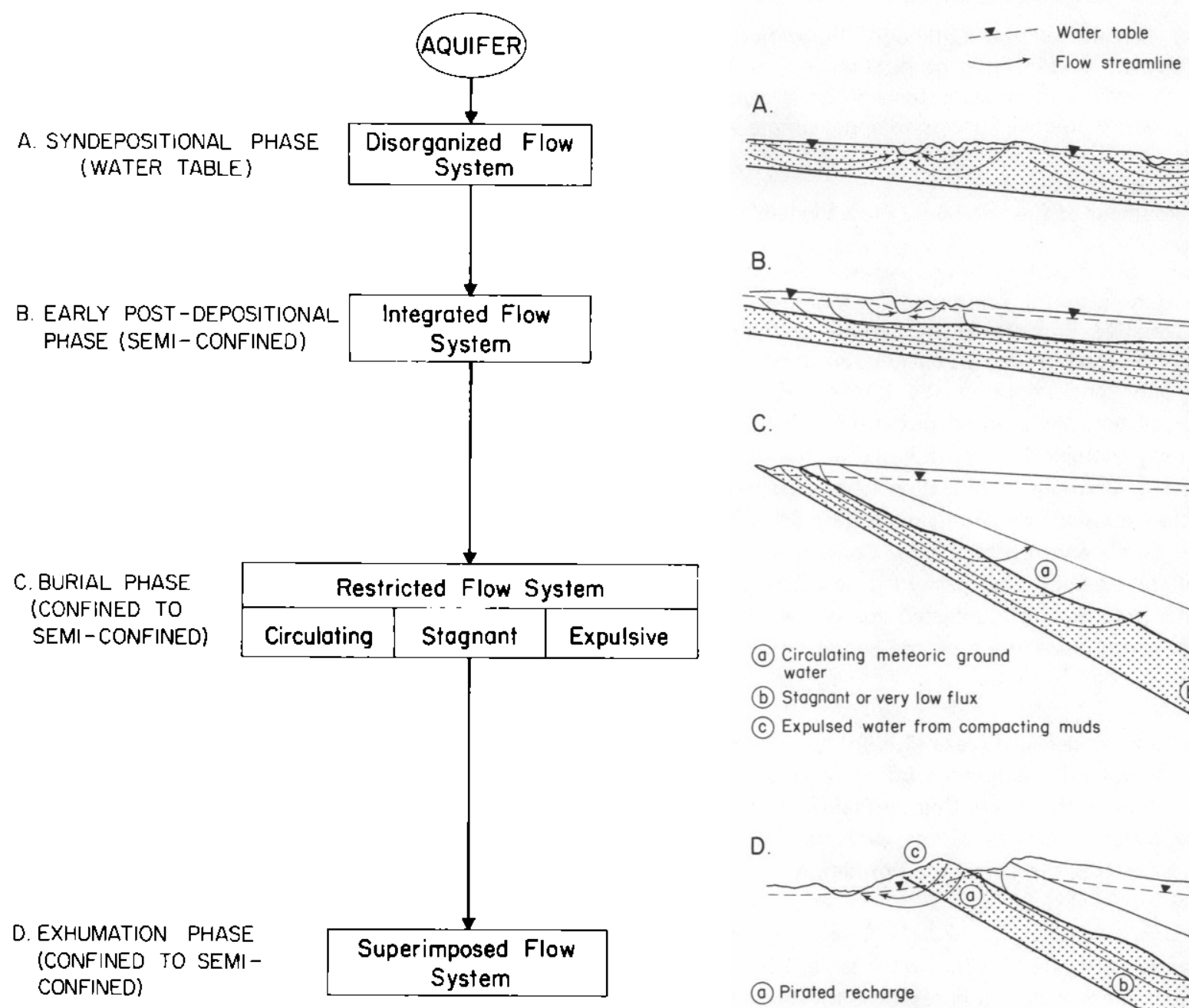

A.

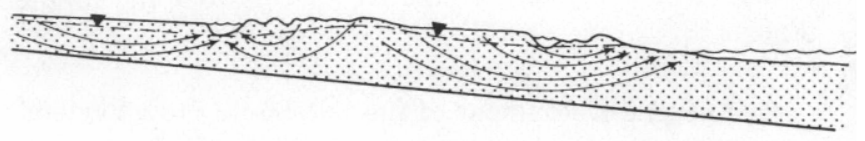

B.
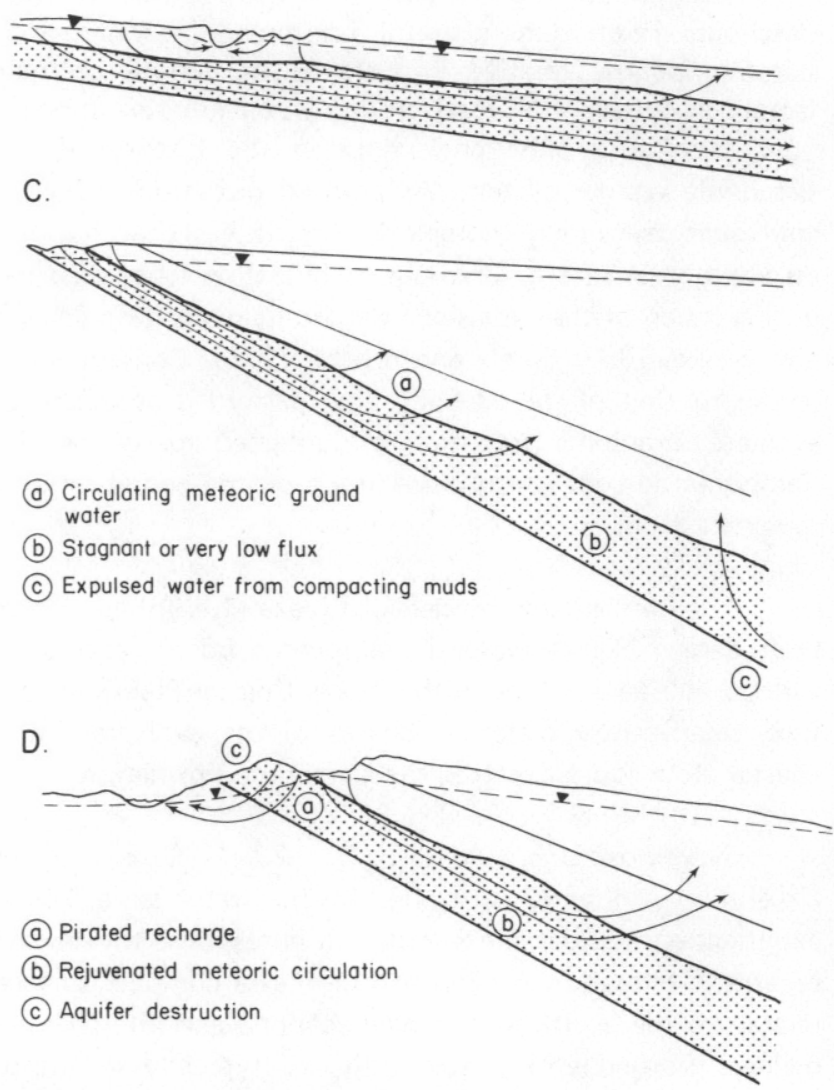

Figure 23. Historical flow phases of a terrigenous coastal plain aquifer system.

Reconstruction of the flow history has several important implications for interpretation of uranium distribution in the Catahoula and in other coastal plain units:

1. Gross aquifer permeability is greatest at the time of deposition and decreases thereafter. Maximum groundwater flux exists, therefore, during early stages of the flow system.

2. Organized, coherent, long-lived flow patterns develop as the system becomes semiconfined in the early post-depositional phase and probably reach maximum stability in the burial phase.

3. Recharge during the early post-depositional phase achieves the most efficient sweep through finer grained sediments interbedded with or overlying permeable units. Sweep decreases as recharge becomes more confined to the outcrop belt during the later phases.
Obviously, the flow phase or phases responsible for concentration of large uranium deposits will determine the relative importance of geologic variables that influence ore formation; conversely, known uranium distribution can be used to determine the phase or phases that prevailed during mineralization.

\section{POST-DEPOSITIONAL DIAGENETIC FEATURES}

Post-depositional alteration has significantly modified Catahoula sediments, both texturally and mineralogically. These modifications are both a consequence of groundwater flux through the section and a control on that flux.

The following discussion is based on petrographic analysis of both sands and muds selected from a suite of over 300 samples collected for this study. Additional 
petrographic data from McBride and others (1968), Thomas (1960), and McCracken (1967) were incorporated in the interpretations.

\section{Sand and Sandstone}

Diagenetic sequences in sands of both the Gueydan and Chita-Corrigan fluvial systems are similar, in spite of the differing framework mineralogies. The complete sequence includes, from earliest to latest: (1) clay coats or cutans around framework grains, (2) patchy micrite cement, (3) montmorillonite matrix, (4) clinoptilolite rims, (5) sparry calcite pore fill, and (6) opal and chalcedony pore fill. Typically, only two or three cements are present in any one sample. Minor mineral phases, whose relationship to the overall diagenetic sequence could not be determined, include patchy analcite pore fill and fibrous mordenite.

Stratigraphic relationships, paragenetic sequence, and morphologic characteristics of the cements indicate a three-stage diagenetic history, which is consistent with the geological history of the updip part of the Catahoula.

Stage 1-Pedogenesis: Clay coats of finely crystalline montmorillonite or amorphous aluminosilicates were deposited around sand grains by illuviation (Brewer, 1964) during soil formation. As soil profiles matured, micritic calcium carbonate also formed, commonly as discrete to diffuse nodules.

Stage 2-Shallow burial: Upon shallow burial, sands were flushed by circulating meteoric ground waters and the continued alteration of contained and surrounding unstable minerals and glass resulted in the formation of additional montmorillonite matrix, clinoptilolite (a hydrous calcium zeolite) rims around detrital grains and within matrix, and sparry calcite pore fill. Sparry calcite also replaced feldspar grains. In the few samples where all stage 2 cements are present, clinoptilolite is intermixed with the montmorillonite matrix, but predates the sparry calcite. In a few samples, ash shards have been completely leached, leaving only the montmorillonite cutan ghost.

Stage 3-Outcrop weathering: Published studies that have relied on outcrop samples record common opal and chalcedonic cements. This siliceous phase appears to be a surficial phenomenon; no samples from pits or cores contained significant opal or chalcedony pore fill. In the Chita-Corrigan system, sands at outcrop commonly display second cycle clay cutans intermixed with finely crystalline silica, producing a white or cream matrix.

Stage 1 clay coats and stage 2 montmorillonite matrix and carbonate cement are most abundant in the volcanic- rich sands of the Gueydan system and decrease northeast in the Chita-Corrigan system. Consequently, the average modern permeability of Gueydan sands (which are somewhat coarser and, therefore, were initially more permeable) is considerably lower than that of the Chita-Corrigan sands. Pump test data show an order-of-magnitude decrease in average aquifer permeability southward from the Sabine River to Webb County.

\section{Volcanic Ash}

The alteration history of volcanic ash is complex. The following sequence is suggested, based on megascopic and microscopic interrelationships of pedogenic features, clay, and preserved shards.

Stage 1-Pedogenesis: Very finely crystalline or amorphous aluminosilicate was dispersed through the zone of soil formation by surficial alteration of ash shards. Fine silt- and clay-sized ash particles may have been completely destroyed (E. C. Jonas, personal communication). Montmorillonite formed in well-drained environments, but significant amounts of kaolinite (or allophane) formed in stagnant, densely vegetated interchannel environments of the Chita-Corrigan system.

Stage 2-Shallow burial: Circulation of meteoric waters through permeable ashy silts and sands and slower percolation through muds completed the alteration of ash to clay minerals containing minor amounts of zeolite, christobalite, and free $\mathrm{SiO}_{2}$. Similar diagenesis of Tertiary fluvial ash deposits in West Texas by circulating meteoric ground waters has been documented by Walton (1975). In most fine-grained ash units, the transformation to clay was complete, and originally permeable, porous ash was converted to impermeable tuffaceous mudstone. Timing of this transformation is unknown, and the rate of alteration would depend on the flux and geochemistry of the circulating ground waters. Nonetheless, the process would have begun very soon after deposition.

Stage 3-Outcrop weathering: South of Fayette County, outcropping tuffaceous beds are commonly calichified. The calichification event has been correlated with a drier climate in the Late Pleistocene (Eargle and others, 1975) and has resulted in destruction of clay minerals and zeolite.

Argillation of ash has sharply reduced the permeability of crevasse splay facies of both the Gueydan and Chita-Corrigan fluvial systems. Units that now constitute aquitards may have acted as fair to good conduits for ground-water flux in the early phases of ground-water flow history. 


\section{Organic Material}

Detrital carbonaceous debris is not abundant in the Catahoula Formation, but is found in the Gueydan fluvial system in Starr County and is common in crevasse and lacustrine facies of the Chita-Corrigan fluvial system. In contrast, silicified wood and argillized root traces are common in both systems.

Formation of clay around roots probably is an early diagenetic feature produced in a local geochemical environment caused by decay of the root. Silicification of woody debris, in contrast, seems to have a more complicated history. Reworked, rounded, silicified wood pebbles within Catahouia channel fills suggest that silicification had gone to completion in previously deposited sediments, probably of older Catahoula or Jackson vintage. Wood fragments can also be rounded during fluvial transport so the evidence is not conclusive. Fresh exposures in the Chita-Corrigan system of East Texas show a progression from silicified wood in the shallow weathered zone to fresh, unaltered carbonaceous logs in immediately underlying, gray, unoxidized sediments (fig. 24). Splintery, poorly silicified wood is an intermediate stage in alteration. Silicification of more finely disseminated carbonaceous debris produces nondescript white, argillaceous blebs.

The ubiquitous evidence for vegetation, local preservation of organic debris in both systems of the Catahoula,

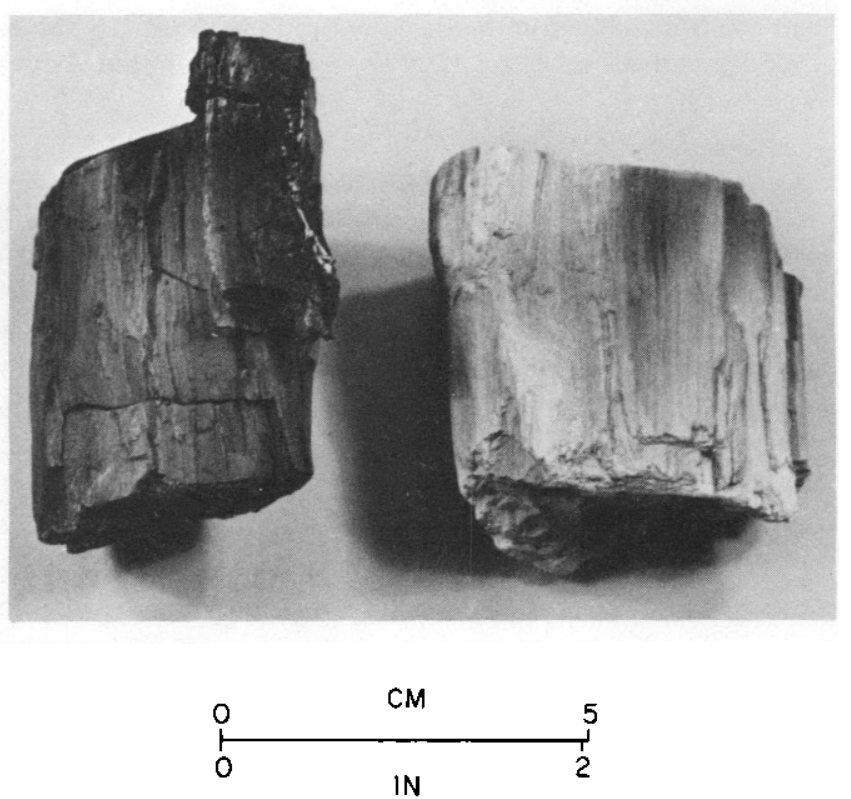

Figure 24. Carbonaceous log and silicified log collected from the same road metal pit. Silicification of wood occurs at the boundary between reduced and surficially oxidized sediments in a progradational crevasse splay lacustrine sequence (Walker County).

and abundance of in situ silicified wood suggest that considerable dissolved humic acids have been and are being mobilized within the Catahoula ground-water flow system.

\section{SOURCE, DISTRIBUTION, AND MIGRATION OF URANIUM IN CATAHOULA FLUVIAL SYSTEMS}

The distribution of uranium in the Catahoula fluvial systems is interpreted on the basis of chemical analysis of 103 samples collected for this study and analyses reported by Duex (1971), on regional airborne gamma-ray spectrometry (E.R.D.A., 1975), and on the distribution of known mineralization. The sampling program emphasized probable source lithologies and was designed to establish background uranium content rather than to define areas of anomalous concentration.

\section{SOURCE OF URANIUM}

Volcanic ash is the presumed source of the uranium deposits in the Texas Coastal Plain, and many authors have placed particular emphasis on the volcanic debris in the Catahoula (Eargle and others, 1975). Arguments for this origin are indirect, but compelling:

1. Tuffaceous beds are stratigraphically associated with all major uranium districts in the United States (Grutt, 1971).
2. Granitic debris, which has been proposed as an al ternate source in some uranium districts, is scarce to absent in coastal plain sediments.

3. The uranium content of highly siliceous extrusive rocks can be quite high (Adams, 1954) and is readily mobilized by weathering.

Determination of the original uranium content of the volcanic ash is considerably more difficult. Even the freshest ash beds in the Catahoula have been exposed to circulating waters, and such flushing can leach large volumes of soluble materials, including metals (Taylor and Stoiber, 1973). In addition, devitrification and argillation are ubiquitous. Data presented by Adams (1954) and Gottfried and others (1962) suggest that a range of 10 to 20 parts per million (ppm) is reasonable for fresh, highly siliceous volcanic rocks. Such a range is compatible with results and interpretation of the uranium analyses, and uranium contents in excess of $20 \mathrm{ppm}$ will be interpreted in this report to indicate enrichment. Contents below 5 ppm 
can reasonably be inferred to indicate significant depletion of original uranium content.

\section{BACKGROUND URANIUM CONTENT}

Uranium content of 67 samples from the Gueydan fluvial system averages between 2 and 3 ppm (on the basis of fluorometric analysis). The median is $1 \mathrm{ppm}$. The average of 36 samples from the Chita-Corrigan fluvial system is 5 ppm; the median value is slightly in excess of $1 \mathrm{ppm}$. Sample data are tabulated in table 2. These data suggest a nearly uniform background uranium content for the Catahoula Formation across the entire coastal plain. Average bismuth 214 gamma radiation recorded on the ERDA spectrographic survey (fig. 25) generally confirms the regional equivalency of the two systems; however, both the average bismuth 214 activity and the bismuth/thallium ratio increase substantially south of Live Oak County. This broad anomaly may reflect the presence of abundant surface uranium shows associated with chalcedony knobs and with shallow, oxidized uranium deposits that occur in this area. Areas of known deposits were avoided in the surface sampling program.
Average uranium content of surface (zone of weathering) and subsurface samples (collected from open pit mines or cores) can be compared in the Gueydan system. No consistent pattern is evident; the averages and medians of the two sample suites are comparable. This suggests that outcrop sample data, if carefully collected, provide a reasonable measurement of uranium content. Similarly, background bismuth gamma radiation recorded across the Catahoula outcrop belt shows no consistent relationship to the northeastward climatic gradient or changing soil type and vegetal cover (fig. 25).

Plots of average and median uranium content against inferred environment of deposition and average grain size of the sample (fig. 26) reveal two significant relationships:

1. Average uranium content of all samples increases slightly with decreasing grain size, but median values show no consistent trend. Averages are biased by a few uraniumenriched lacustrine muds and clays.

2. Average and median uranium values are correlative with interpreted depositional environment of the sampled unit. Environments characterized by most intense leaching

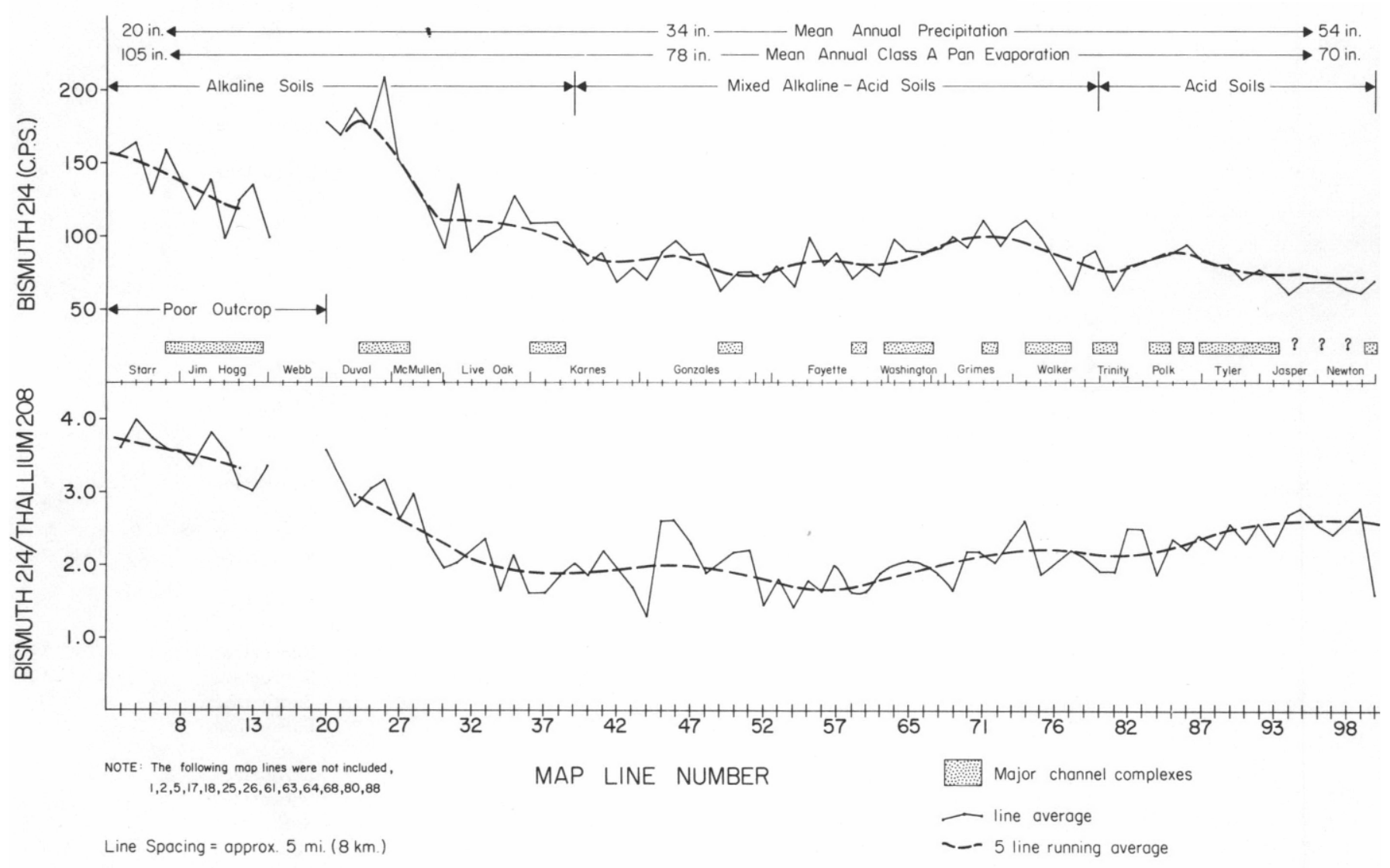

Figure 25. Average bismuth and bismuth-thallium gamma radiation recorded by a regional gammaradiation spectral survey (E.R.D.A., 1975) across the Catahoula outcrop belt. Survey consisted of dip-oriented flight lines spaced at approximately five-mile intervals. Average gamma intensity (measured in counts per second) across the Catahoula outcrop was visually approximated for each flight (map) line and plotted. A five line running average was calculated to smooth the data and emphasize regional trends. 
Table 2. Uranium content of Catahoula samples determined by fluorometric analysis.

\begin{tabular}{|c|c|c|c|c|c|}
\hline County & $\begin{array}{l}\text { Sample } \\
\text { Number }\end{array}$ & Composition & $\begin{array}{l}\text { Depositional } \\
\text { Environment }\end{array}$ & $\begin{array}{l}\text { Surface or } \\
\text { Subsurface }\end{array}$ & ppm U $U_{3} O_{8}$ \\
\hline \multirow[t]{2}{*}{ Webb } & $\begin{array}{l}6 / 18-2 \\
6 / 18-3\end{array}$ & $\begin{array}{l}\text { Tuffaceous Mud } \\
\text { Tuffaceous Mud }\end{array}$ & $\begin{array}{c}? \\
\text { Paleosoil on } \\
\text { Crevasse Splay }\end{array}$ & $\begin{array}{l}\text { Surface } \\
\text { Surface }\end{array}$ & $<2$ \\
\hline & $6 / 20-1$ & Mud & $\begin{array}{l}\text { Primary Oxidized } \\
\text { Soil }\end{array}$ & Subsurface & 1 \\
\hline \multirow[t]{2}{*}{ Duval } & $\begin{array}{l}8 / 17 \cdot 1 \mathrm{a} \\
8 / 17 \cdot 1 \mathrm{~b} \\
8 / 17 \cdot 2 \\
8 / 17 \cdot 3\end{array}$ & $\begin{array}{l}\text { Ashy Mud } \\
\text { Mud } \\
\text { Tuffaceous Silt } \\
\text { Muddy Sand }\end{array}$ & $\begin{array}{l}\text { Fluvial Channel } \\
\text { Fluvial Channel } \\
\text { Crevasse Splay? } \\
\text { Crevasse Splay or } \\
\text { Fluvial Channel }\end{array}$ & $\begin{array}{l}\text { Surface } \\
\text { Surface } \\
\text { Surface } \\
\text { Surface }\end{array}$ & $\begin{array}{r}5 \\
<1 \\
5 \\
<1\end{array}$ \\
\hline & $\begin{array}{l}8 / 17-4 \\
8 / 17-5 a\end{array}$ & $\begin{array}{l}\text { Tuffaceous Mud } \\
\text { Mud }\end{array}$ & $\begin{array}{l}\text { Lacustrine } \\
\text { Floodplain }\end{array}$ & $\begin{array}{l}\text { Surface } \\
\text { Surface }\end{array}$ & $\begin{array}{l}3 \\
2\end{array}$ \\
\hline \multirow[t]{20}{*}{ Live Oak } & $1 / 22-1 a$ & Ashy Silt & $\begin{array}{l}\text { Paleosoil on } \\
\text { Crevasse Splay }\end{array}$ & Subsurface & 2 \\
\hline & $1 / 22-1 b$ & Ashy Silt & $\begin{array}{l}\text { Paleosoil on } \\
\text { Crevasse Splay }\end{array}$ & Subsurface & 2 \\
\hline & $1 / 22 \cdot 1 c$ & Sandy Mud & Floodplain & Subsurface & 6 \\
\hline & $1 / 22 \cdot 1 d$ & Micrite & Floodplain & Subsurface & 3 \\
\hline & $1 / 22-2 a$ & Tuffaceous Mud & Crevasse Splay & Subsurface & 14 \\
\hline & $1 / 22-2 c$ & Mud & Crevasse Splay & Subsurface & $<1$ \\
\hline & $1 / 22-2 d$ & Mud & Crevasse Splay & Subsurface & 2 \\
\hline & $1 / 22-2 \mathrm{e}$ & Clay & Crevasse Splay & Subsurface & 1 \\
\hline & $3 / 4-10$ & Sandy Mud & Crevasse Splay & Subsurface & 3 \\
\hline & $3 / 4-11$ & Ashy Silt & Crevasse Splay & Subsurface & 2 \\
\hline & $3 / 4-12$ & Sandy Mud & Crevasse Splay & Subsurface & 6 \\
\hline & $3 / 4-13$ & $\begin{array}{l}\text { Mud Clast } \\
\text { Conglomerate }\end{array}$ & Crevasse Splay & Subsurface & 13 \\
\hline & $3 / 4-14 b$ & Sandy Mud & $\begin{array}{l}\text { Paleosoil on } \\
\text { Crevasse Splay }\end{array}$ & Subsurface & 1 \\
\hline & $3 / 4-14 a$ & Clay & $\begin{array}{l}\text { Primary Oxidized } \\
\text { Soil }\end{array}$ & Subsurface & 1 \\
\hline & $3 / 4-15$ & Clay & $\begin{array}{l}\text { Primary Oxidized } \\
\text { Soil }\end{array}$ & Subsurface & 1 \\
\hline & $\begin{array}{l}3 / 4-16 \\
3 / 4-17\end{array}$ & $\begin{array}{l}\text { Silt } \\
\text { Muddy, Very Fine } \\
\text { Sand }\end{array}$ & $\begin{array}{l}\text { Lacustrine } \\
\text { Lacustrine }\end{array}$ & $\begin{array}{l}\text { Subsurface } \\
\text { Subsurface }\end{array}$ & $\begin{array}{l}8 \\
3\end{array}$ \\
\hline & $\begin{array}{l}3 / 4-18 \\
3 / 4-20\end{array}$ & $\begin{array}{l}\text { Sandy Mud } \\
\text { Mud }\end{array}$ & $\begin{array}{l}\text { Crevasse Splay } \\
\text { Primary Oxidized } \\
\text { Soil }\end{array}$ & $\begin{array}{l}\text { Subsurface } \\
\text { Subsurface }\end{array}$ & $\begin{array}{r}<1 \\
2\end{array}$ \\
\hline & $6 / 2-1 b$ & Ash & Crevasse Splay & Surface & $<1$ \\
\hline & $6 / 2-3$ & Clay & Lacustrine & Surface & 1 \\
\hline & $\begin{array}{l}6 / 1-5 \\
6 / 1-6 a\end{array}$ & $\begin{array}{l}\text { Tuffaceous Silt } \\
\text { Ashy Mud }\end{array}$ & $\begin{array}{l}\text { Crevasse Splay } \\
\text { Floodplain }\end{array}$ & $\begin{array}{l}\text { Surface } \\
\text { Surface }\end{array}$ & $\begin{array}{r}1 \\
<1\end{array}$ \\
\hline \multirow[t]{13}{*}{ Karnes } & $\begin{array}{l}12 / 15-1 \\
12 / 15-2 \\
12 / 15-4 \\
12 / 15-5\end{array}$ & $\begin{array}{l}\text { Tuffaceous Mud } \\
\text { Ashy Silt } \\
\text { Tuffaceous Mud } \\
\text { Ashy, Very Fine } \\
\text { Sand }\end{array}$ & $\begin{array}{l}\text { Lacustrine } \\
\text { Lacustrine } \\
\text { Floodplain? } \\
\text { Floodplain }\end{array}$ & $\begin{array}{l}\text { Subsurface } \\
\text { Subsurface } \\
\text { Subsurface } \\
\text { Subsurface }\end{array}$ & $\begin{array}{l}4 \\
4 \\
1 \\
2\end{array}$ \\
\hline & $12 / 15-6$ & Clay & $\begin{array}{l}\text { Paleosoil on } \\
\text { Crevasse Splay }\end{array}$ & Subsurface & 2 \\
\hline & $\begin{array}{l}12 / 15-7 \\
12 / 15-10\end{array}$ & Mud & $\begin{array}{l}\text { Crevasse Splay } \\
\text { Fluvial Channel }\end{array}$ & $\begin{array}{l}\text { Subsurface } \\
\text { Subsurface }\end{array}$ & $<1$ \\
\hline & $12 / 15-13$ & Silty Tuff & Lacustrine & Subsurface & $\begin{array}{r}1 \\
6\end{array}$ \\
\hline & $1 / 22-3$ & $\begin{array}{l}\text { Medium to Coarse } \\
\text { Sand }\end{array}$ & Fluvial Channel & Subsurface & 1 \\
\hline & $1 / 22-4$ & Medium Sand & Fluvial Channel & Subsurface & 2 \\
\hline & $1 / 22-5 a$ & Mud & Crevasse Splay & Subsurface & $<1$ \\
\hline & $1 / 22-5 b$ & Tuff & Crevasse Splay & Subsurface & $<1$ \\
\hline & $1 / 22.7$ & $\begin{array}{l}\text { Medium to Coarse } \\
\text { Sand }\end{array}$ & Fluvial Channel & Subsurface & $<1$ \\
\hline & $1 / 22-9$ & $\begin{array}{l}\text { Fine to Medium } \\
\text { Sand }\end{array}$ & Fluvial Channel & Subsurface & 2 \\
\hline & $1 / 22 \cdot 10$ & Fine Sand & Fluvial Channel & Subsurface & 1 \\
\hline & $1 / 22-11$ & Medium Sand & Fluvial Channel & Subsurface & 1 \\
\hline & $1 / 22-12$ & $\begin{array}{l}\text { Fine to Medium } \\
\text { Sand }\end{array}$ & Fluvial Channel & Subsurface & 2 \\
\hline
\end{tabular}




$1 / 22-13$
$3 / 4-1$
$3 / 4-2$
$3 / 4-3$
$3 / 4-6$
$3 / 4-7$
$3 / 4-8$
$3 / 5-2$
$3 / 5-10$
$3 / 11-1$
$3 / 11-3$
$3 / 11-4$
$3 / 11-6$
$3 / 11-7$
$3 / 11-8$
$6 / 1-2 \mathrm{a}$
$6 / 1-2 \mathrm{~b}$

Fayette

$3 / 31-4 b$

2/23-1a

2/23-26

Washington

$3 / 26-2$

$3 / 26-4 a$

$3 / 26-7$

$3 / 26 \cdot 8$

$3 / 30-5$

3/30-6a

$3 / 30 \cdot 7 b$

3/31-3a

$3 / 31-3 b$

3/30-6b

4/27-1

Grimes

4/28-1a

4/28-1c

4/28-2a

5/4-4

Brazos

$4 / 27-4 a$

Walker

Jasper

Newton

5/5-1a

5/5-3a

$5 / 5-7 \mathrm{c}$

$5 / 5-9$ a

$5 / 5-9 b$

$5 / 17-3 \mathrm{~b}$

$5 / 17-3 c$

5/18-1

$5 / 18-6 c$

5/18-10

$6 / 8-2 b$

6/8-6a

6/9-1a

6/9-5a

6/8-7a
Clay

Medium Sand

Muddy Silt

Mud

Medium Sand

Muddy Fine Sand

Muddy Fine Sand

Fine to Medium

Sand

Medium Sand

Mud

Medium Sand

Tuffaceous Mud

Medium Sand

Very Fine Sand

Very Fine Sand

Tuffaceous Mud

Very Fine Sand

Medium to Coarse Sand

Tuffaceous Silt

Ashy, Very Fine Sand

Silt

Argillaceous Silt

Very Fine Sand

Very Fine Sand

Sandy Mud

Mud

Medium Sand

Silt

Coarse Sand

Mud

Ash

Muddy Fine Sand

Mud

Fine Sand

Medium to Coarse Sand

Fine to Medium Sand

$6 / 8-7 b$

$6 / 8-7 c$

$6 / 8-7 d$
Sandy Silt

Mud

Silt

Mud

Mud

Mud

Clay

Silt

Fine Sand

Mud

Mud

Mud

Mud

Mud

Clay

Mud

Ashy Silt

Mud
Fluvial Channel

Fluvial Channel

Fluvial Channel

Fluvial Channel

Crevasse Splay

Crevasse Splay

Crevasse Splay

Fluvial Channel

Fluvial Channel

$$
\text { ? }
$$

Fluvial Channel ?

Crevasse Splay

Floodplain

Crevasse Splay

Paleosoil on

Crevasse Splay?

Fluvial Channel

Fluvial Channel

Crevasse Splay

Fluvial Channel

Crevasse Splay

Floodplain

Fluvial Channel

Fluvial Channel

Paleosoil on

Crevasse Splay

Paleosoil on

Crevasse Splay

Fluvial Channel

Floodplain

Fluvial Channel

Paleosoil on

Crevasse Splay

Crevasse Splay

Paleosoil on

Crevasse Splay

Crevasse Splay

Fluvial Channel

Crevasse Splay

Fluvial Channel

Crevasse Splay

Floodplain

Lacustrine

Lacustrine

Lacustrine

Lacustrine

Lacustrine

Floodplain

Fluvial Channel

Floodplain

Floodplain

Paleosoil on

Crevasse Splay

Lacustrine

Lacustrine

Lacustrine

Lacustrine

Lacustrine

Lacustrine
Subsurface

Subsurface

Subsurface

Subsurface

Subsurface

Subsurface

Subsurface

Subsurface

Surface

Subsurface

Subsurface

Subsurface

Surface

Surface

Surface

Surface

Surface

Subsurface

Surface

Surface

Surface

Surface

Surface

Surface

Surface

Surface

Surface

Surface

Surface

Surface

Surface

Surface

Surface

Surface

Surface

Surface

Surface

Surface

Surface

Surface

Surface

Surface

Surface

Surface

Surface

Surface

Surface

Surface

Surface

Surface

Surface

Surface

Surface

Surface
$<1$

$<1$

10

2

1

12

2

5

2

$<1$

8

3

2

2

2

2

5

1
6

$<1$

$<1$

$<1$

8

2

1

4

$<1$

1

3

36

$<1$

1

1
1

41

$<1$

3

11 

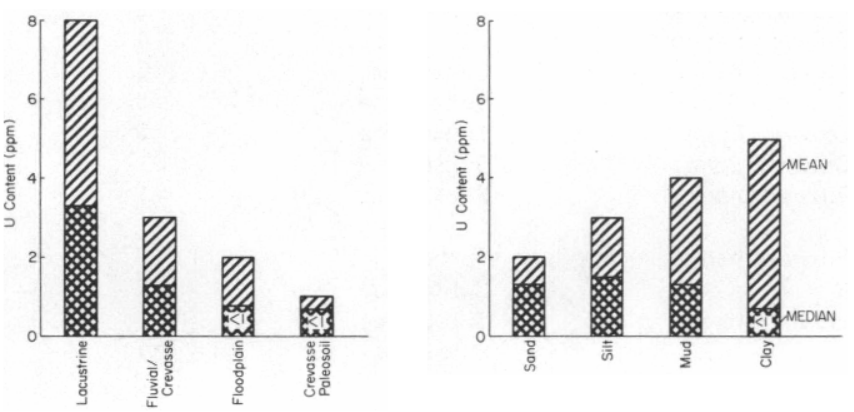

Figure 26. Average and median uranium content of 103 samples grouped by grain size and inferred depositional environment. All samples were collected in areas removed from known mineralization fronts. Analyses were made fluorometrically with $1 \mathrm{ppm}$ accuracy at the low concentrations found in most samples. Samples registering less than $1 \mathrm{ppm} \mathrm{U}_{3} \mathrm{O}_{8}$ were rounded to $1 \mathrm{ppm}$ in calculations of mean and median.

and soil formation (crevasse soil and floodplain) have uniformly low values (less than $1 \mathrm{ppm}$ for all paleosoils). The lacustrine environment, which was least subjected to syndepositional subaerial leaching by percolating meteoric waters, has the highest median uranium content. Further, the enriched samples are both lacustrine. Fluvial and crevasse deposits have intermediate uranium contents.

The analytical data support the conclusion that Catahoula sediments have been efficiently depleted of uranium, as proposed by Moxham (1964) and Duex (1971). and suggest that the leaching event occurred very soon after deposition of the sediments. The latter hypothesis is supported by the apparent relationship between trace uranium content and the inferred degree of syndepositional pedogenesis of the sampled facies and by the fact that significant redistribution of uranium is evident in even the most impermeable claystones (compare samples 5/17-3c with 6/8-7a).

\section{CHARACTERISTICS AND DISTRIBUTION OF URANIUM ENRICHMENT}

Uranium concentration in excess of $20 \mathrm{ppm}$ is assumed to indicate some enrichment above the original content of the source ash. Commercial ore bodies are simply unusually large, rich concentrations.

The distribution of known commercial and subcommercial ore deposits is shown on plates I, III, and IV and figure 6 . In addition, surface anomalies shown by Eargle and others (1971) have been plotted. Shallow oil well gamma-ray log anomalies and sample uranium concentration are shown only for the Chita-Corrigan system.

The spatial distribution of uranium anomalies relative to other geologic variables, such as sand distribution, faults, and underlying hydrocarbons, indicates that regional uranium content is not uniquely controlled by any one variable. However, certain interrelationships are apparent and can be examined in shallow portions of the Gueydan fluvial system where exploration has been most active. Figure 27 summarizes the pattern of uranium concentration relative to major fault zones and facies trends. Five areas containing numerous radioactivity anomalies and known deposits are outlined.

Area 1 contains several small deposits and gamma-ray log anomalies concentrated along the flank of the largest belt of Gueydan fluvial sands and along a south-trending

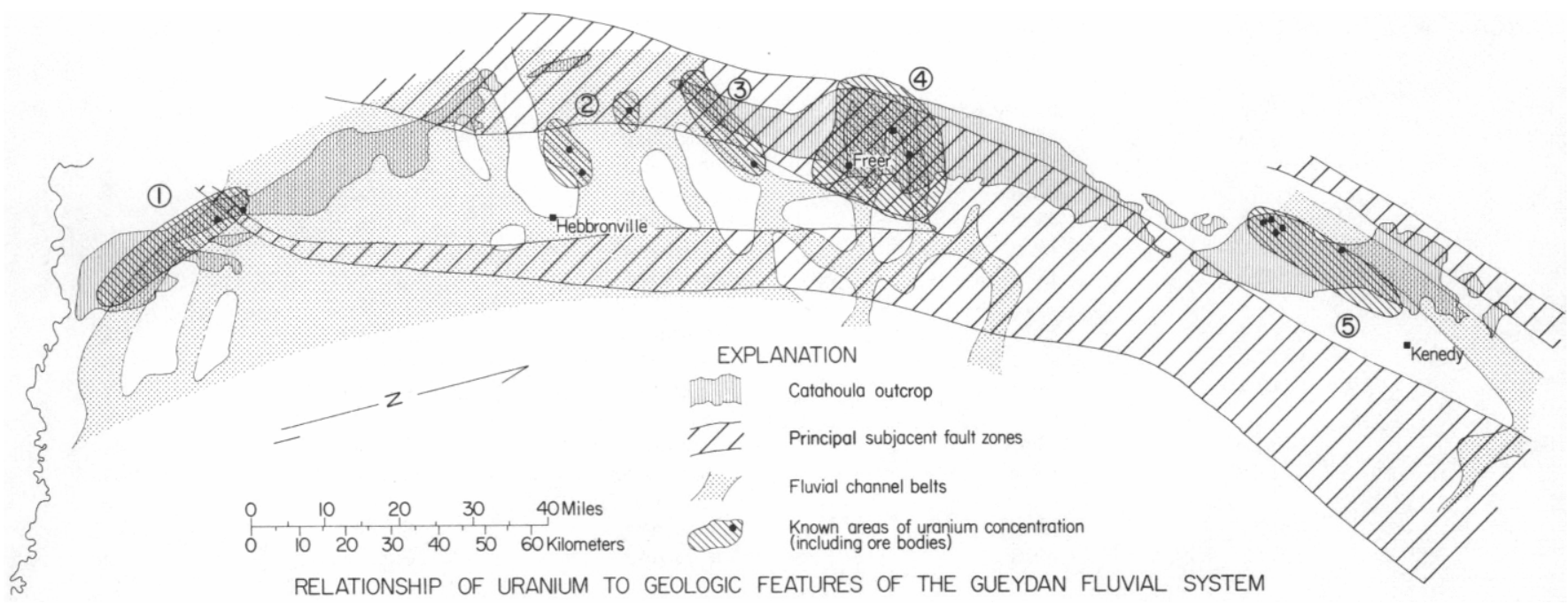

Figure 27. Distribution of known uranium ore deposits and areas of abundant anomalies within the structural and stratigraphic framework of the Gueydan fluvial system. 
channel complex that lies in the shallow subsurface. A narrow fault zone intersects the area near the two known ore bodies.

Area 2 contains several small- to medium-sized ore bodies along the south margin of a major channel complex and along the margin of relatively sand-poor areas within the sand belt. Most of area 2 is downdip from the belt of growth faults. Ore bodies may be several miles from the nearest known fault, and the mineralized alteration fronts tend to parallel facies boundaries rather than fault trends.

Area 3 contains several small surface and shallow subsurface shows and deposits that occur along the northern margin of an oblique-trending salient off of the larger sand belt. Most of the area also lies within a fault zone.

Area 4 encloses a swarm of uranium shows and small, shallow ore bodies that all lie within the intersection of a subsidiary channel complex and a broad, strike-parallel fault zone. This area includes many siliceous-carbonate knobs and has a uniformly high airborne gamma activity (fig. 25).

Area 5 contains a number of small ore bodies that lie at the base of the Catahoula Formation within a zone of interfingering between tuffaceous crevasse splay and coastal lake facies (fig. 6). Like other areas, it too is located on the flank of a major channel belt, which trends northeast across southern Karnes County, but which has been erosionally truncated in the area of the uranium deposits. Area 5 is also significant in that mineralization is about as far removed from fault zones as is possible in the South Texas Coastal Plain.

In summary, shallow mineralization is concentrated along the flanks of the principal belts of the fluvial channel facies and rarely occurs along the axes of major sand belts or within floodplain facies. The relationship to faults is less well defined. Ore grade mineralization obviously can occur far removed from significant faults. On the other hand, the intersection of favorable channel-fill and crevasse facies with a fault zone produces multiple uranium anomalies and at least some ore grade mineralization.

In addition to a possible direct relation to faults, Eargle and Weeks (1961) postulated a genetic association between uranium ore bodies and underlying petroleum accumulations. Vertical migration of reductants from hydrocarbon-bearing zones has since been invoked by numerous authors (Klohn and Pickens, 1970; McKnight, 1972). The significance of this relationship is examined in figure 28 , which shows the generalized distribution of oil

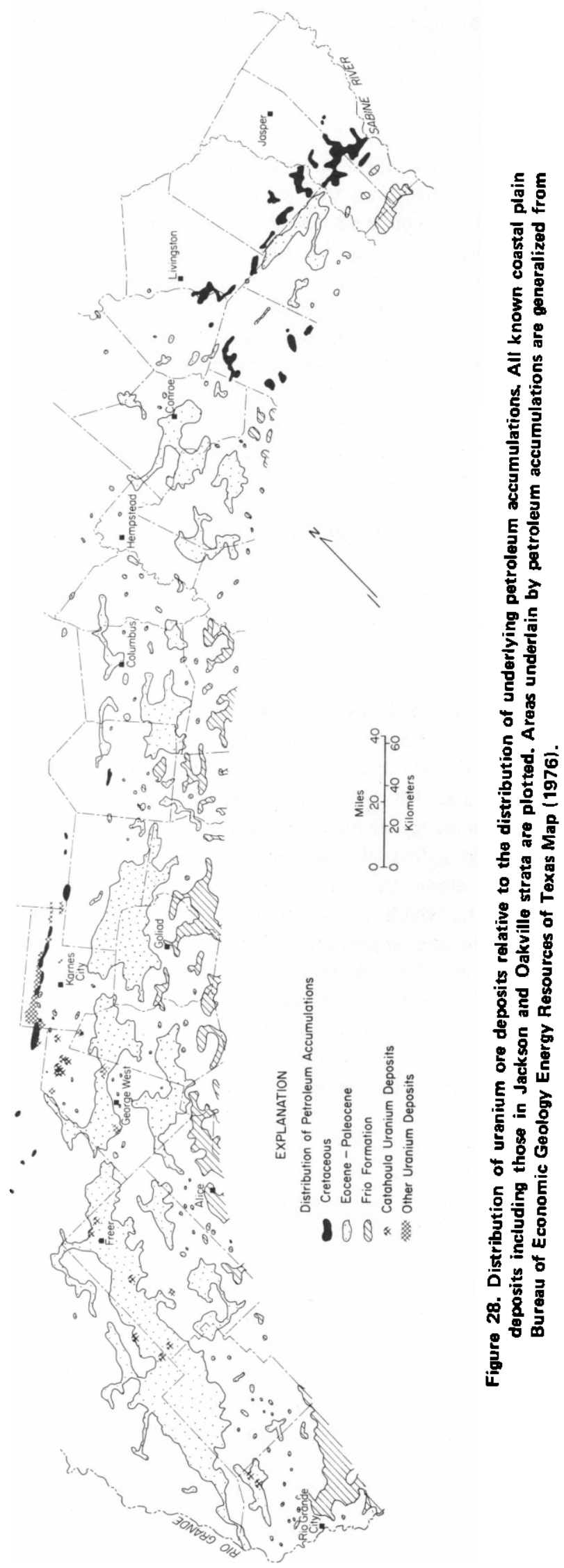


and gas fields (grouped by producing horizon) and of all known ore bodies (including those in the Jackson, Catahoula, and Oakville). It is apparent that the Cretaceous and Early Tertiary section underlying the uranium belt is hydrocarbon rich. An estimated one-third of the South Texas Coastal Plain is underlain by closely spaced petroleum accumulations that are largely fault trapped. Uranium deposits, which also display a relationship to faults, are naturally found along similar trends. However, some notable exceptions are apparent, including northern Live Oak County where Catahoula, Jackson, and Oakville deposits lie outside major belts of hydrocarbon production. As with faults, the presence of hydrocarbon accumulations is not a prerequisite for uranium mineralization. Rather, the abundance of hydrocarbons in stratigraphically lower and equivalent parts of the section suggests a subsurface environment containing abundant mobile reductants.

\section{GEOLOGY OF CATAHOULA ORE BODIES}

Details of the uranium deposits are available only for areas 2 and 5 where limited surface and in situ mining operations have been initiated.

Deposits in area 2 are roll ore bodies that lie along the boundary between secondarily oxidized ${ }^{2}$ (cream to tan) and reduced (gray) sands in the middle part of the Catahoula. The mineralized oxidation fronts are laterally continuous for as much as several miles and are commonly oriented subparallel to facies boundaries. Mineralization occurs along the margin of fluvial channel sand trends (plate 1), which contain tongues of altered sediment. The characteristic appearance of area 2 roll front deposits is shown in figure 29 . The c-shaped ore roll lies within a sand unit. A salient of seep mineralization extends beyond the nose of the roll and an extensive gamma tail trails back into the oxidized interior. Fresh pyrite occurs in reduced sands; iron oxides occur behind the front. This type of ore body exhibits the features of typical roll ore bodies of many Tertiary basins. Size and extent of the deposits are speculativt, but an aggregate proven reserve of several million pounds is reasonable for the geologic setting and recovery efforts to date.

Mineralization occurs as disseminated reduced uranium minerals (presumably uraninite and coffinite) within medium- to fine-grained sands which contain numerous mud lenses, mud clast conglomerates, and abundant diagenetic clay matrix. The host facies may be dominantly proximal crevasse splay rather than the actual

${ }^{2}$ Oxidation is used to describe only the nature of contained iron minerals; alteration is a more general term including all diagenetic and geochemical changes associated with emplacement of a mineral. ization front.

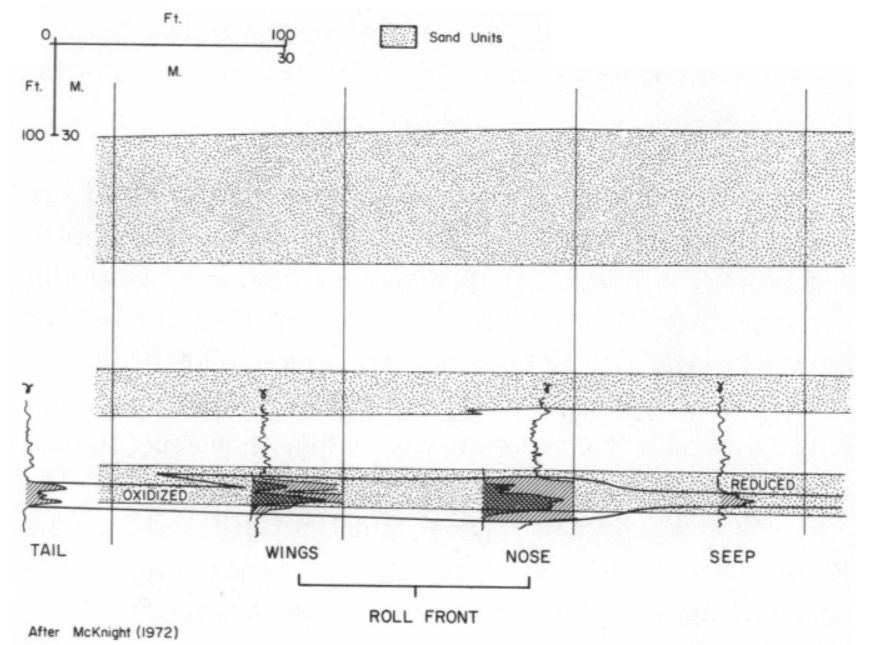

Figure 29. Features of a typical uranium mineralization front in area 2 (after McKnight, 1972). Ore concentration assumes well. known roll geometry with wings trailing updip into oxidized ground and the nose convex toward the unmineralized reduced portions of host sand body.

fluvial channel-fill deposits. The lithic heterogeneity of the section results in relatively low permeabilities for such coarse sediments. Lenses and beds of mudstone and siltstone are common, and the oxidized area behind the nose of the mineralization front is locally very ragged because numerous islands and pods of reduced sediment remain stranded within the oxidized tongues. Alteration tongues are localized within a single sand body in the immediate area of the front; however, the areal extent of such stratigraphic isolation is unknown.

Deposits in area 5 have been partially exposed by surface mining and present some significant contrasts to the deposits of area 2. Area 5 ore bodies occur along laterally continuous mineralization fronts that trend parallel to the margin of a stratigraphically associated channel sand belt (plate 1). However, the front here may not separate oxidized from reduced ground. Sediments may be uniformly dark gray and pyritic on both sides of the mineralization front. In addition, the c-shaped roll geometry of the ore bodies is poorly developed in many transects, and mineralization occurs in a section dominated by sandy mud, clay, and muddy, ashy, very fine-grained sand. The linear, continuous mineralization front is anomalous in a section that now contains nearly impermeable sediments. Sedimentary and petrographic features all indicate mineralization within crevasse splay fine sands and silts that prograded into the updip margin of the coastal lake environment. Mineralization must have predated argillation of the ash during the burial phase, 
which sealed the aquifer and effectively isolated the crevasse deposits from further ground-water flux.

Many shallow uranium deposits are locally being encroached upon by surface oxidation, but mobility of the uranium is severely limited by the impermeable nature of the host facies. Reduced uranium minerals are presumed to be uraninite and coffinite; autunite occurs in oxidized deposits.

\section{SUMMARY OF CATAHOULA URANIUM CYCLE}

Integration of the data presented thus far allows definition of the overall cycle of uranium mobilization, migration, and accumulation within the Catahoula Formation. The cycle is determined by inherent physical, historical, and geochemical attributes of the component depositional systems. Although details of the geochemical reactions operative in the uranium cycle have not been discussed, most proposed geochemical models of uranium ore formation could function within the cycle, provided two fundamental assumptions are met:

1. Uranium must be redistributed through the sedimentary section by mass transfer of ground water.

2. The rate of uranium fixation must be high relative to the flow velocity of the transporting waters.

The first assumption means that diffusion induced by chemical or other gradients does not significantly control the movement of uranium in the regional cycle. The second assumption implies that reasonable ground-water flow (which, in a coastal plain setting ranges from a maximum of a few hundred feet to a minimum of a few feet per year in active aquifers) allows ample contact time for chemical or physiochemical reactions that fix uranium to occur at any point where conditions are favorable for accumulation. Both assumptions are consistent with characteristics of described roll front deposits both in Texas and in other Tertiary basins.

The interpreted Catahoula uranium cycle encompasses four contemporaneous events, which produced the first-order or primary mineralization trends, and two possible subsequent events that modify the primary trends (fig. 30):

1. Uranium was released from the source volcanic ash by early leaching and mineralogical al teration in surface and near-surface environments.

2. Mobilized uranium entered the ground-water flow system in areas of regional recharge. In areas of regional discharge, uranium was flushed by surface drainage into the Gulf of Mexico. Areas of ponded surface waters (lakes or lagoons) may have retained and concentrated a small portion of the uranium that entered the surface drainage.
3. Oxidizing ground waters containing the mobile uranium migrated into coherent flow systems in semiconfined aquifers and produced well-defined salients of altered ground within the regionally reduced portions of the sedimentary section. Reductants included intrinsic organic debris and sulfides contained in facies of both fluvial systems and extrinsic gasses migrating vertically into the aquifer. Regional geometry of alteration fronts was determined primarily by the relative flux of ground water through various parts of the aquifer. Ground-water flux, in turn, was controlled by average permeability, orientation, and degree of vertical interconnection of permeable elements of the aquifer system. Active fault zones formed primary hydrodynamic boundaries that compartmentalized aquifer flow and accentuated cross-stratal movement of ground water.

4. Uranium was concentrated along a discrete mineralization front, which closely paralleled the iron redox front, as flow traversed a geochemical gradient that reduced the solubility of uranium. Such gradients commonly developed and persisted where flow crossed out of channel-fill sands into mixed lithologies containing mud, silt, and clay. Cross flow occurred both horizontally at facies changes and vertically where faulting formed hydrodynamic barriers. However, a geochemical gradient occurred at all margins of the alteration tongue, and uranium concentration was not limited to areas of facies or stratigraphic cross flow. The actual concentrating mechanism might have been chemical precipitation (Hostetler and Garrels, 1962), adsorption of uranium onto clay, zeolite, or organic debris (Doi and others, 1975), or a biochemical reaction.

Later events that modify mineralization trends established in the constructional phase of the uranium cycle include (fig. 30):

5. Post-depositional changes in the flow system caused by compaction and sealing of bounding aquitards, continuing displacement along faults, and diagenetic modification of porous, permeable units locally sealed off or reduced the flux of ground water in many parts of the aquifer. Reequilibration of stagnant portions of the aquifer with the surrounding subsurface reducing environment (likely enhanced by vertical migration of extrinsic reductants along fault zones) rereduced parts of the oxidized tongues and insulated mineralization fronts from further significant migration. Where ground-water flux continues to be active, the oxidized aspect of the alteration tongue is preserved.

6. Outcrop recession exposed parts of shallow mineralization fronts to the oxidizing environment above the water table. Resultant oxidation locally remobilized uranium or produced stable oxidized uranium minerals such as autunite. Such modification did not, however, produce 


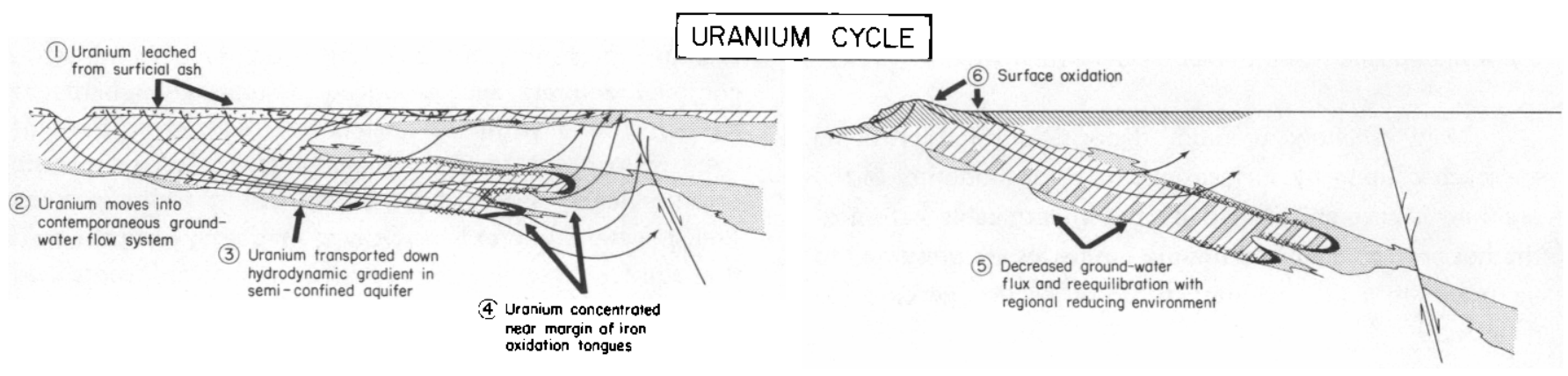

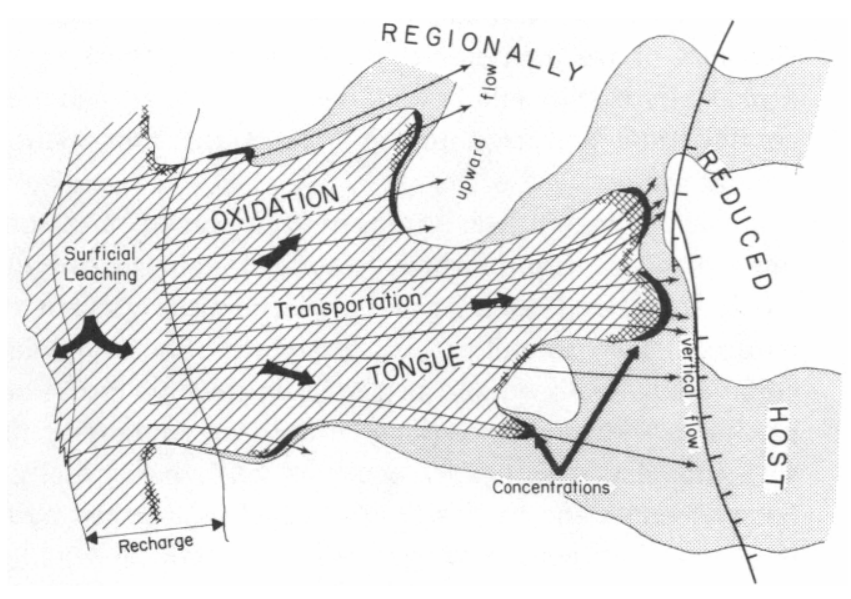

CONSTRUCTIONAL PHASE

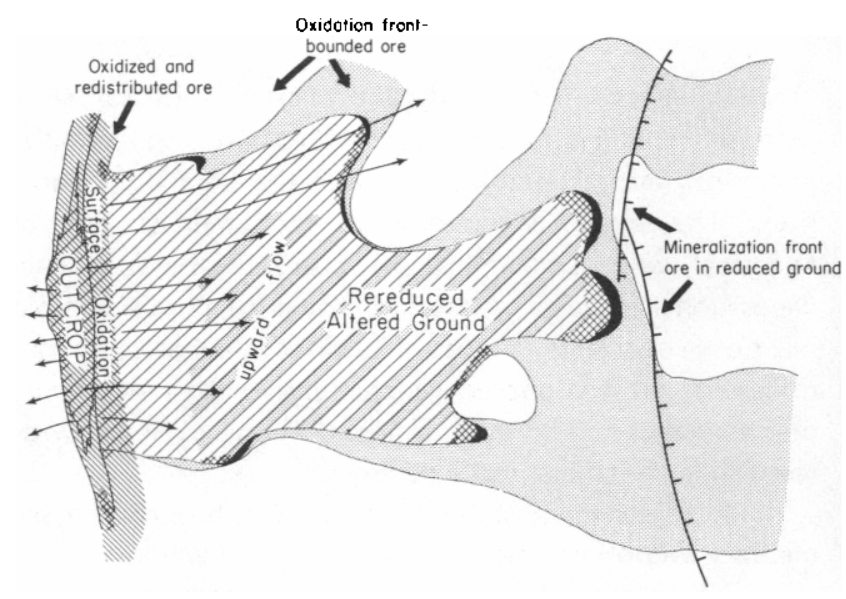

MODIFICATION PHASE

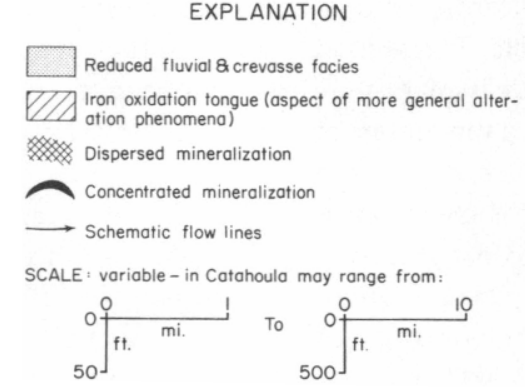

EXPLANATION

Figure 30. Diagrammatic representation of the two principal phases of uranium cycle interpreted for Catahoula fluvial systems. Constructional ovents include primary mobilization, migration, and concentration of uranium within a semiconfined aquifer system contemporaneous with or soon after deposition of volcanic ash in the ground-water recharge area. Development of an extensive oxidation tongue is the most recognizable aspect of more general alteration phenomena that accompany migration and concentration of uranium. Modification of the deposits includes rereduction of oxidized portions of the alteration tongue where the aquifer becomes stagnant, and oxidation. minor remobilization, and destruction of shallow deposits by surface oxidation at or above the ambient water table. Note that the scale on which the cycle operates can vary in proportion to the size of the aquifer system.

extensive renewed migration of coherent alteration fronts. Oxidized ore bodies are on trend with unmodified counterparts of the same front. Significantly, alteration patterns in other uraniferous basins are out of phase with modern hydrodynamic gradients (Butler, 1969) and confirm the concept of a discrete primary mineralizing phase of limited geological duration.
Operation of this cycle is consistent with the known distribution and geologic relationships of uranium ore bodies in the Catahoula Formation. Application of the conceptual framework allows prediction of the extent and probable nature of potential mineralization using known deposits in the Catahoula and in other uranium-producing systems as analogues. 


\section{REGIONAL EXPLORATION CRITERIA}

The uranium cycle within a depositional basin can be compared to an ore-processing mill. Both alter a large volume of rock to extract and concentrate a dispersed element. The amount of enriched product $\left(U_{\text {tot }}\right)$ is equal to the product of the volume of solution moved through the system per unit time (O) multiplied by the duration of the flux $(T)$, the concentration of desired element in the solution (ppm), and the efficiency of the extraction reaction (E):

$$
U_{\text {tot }}=Q \times T \times p p m \times E
$$

Quantification of this expression is impossible in natural systems. Nevertheless, it is obvious that any geologic factor that results in a positive change in $\mathrm{O}, \mathrm{ppm}, \mathrm{E}$, or $\mathrm{T}$ provides a positive exploration criterion. Application of this equation within the framework of the constructional uranium cycle of the Catahoula produces several guidelines for evaluation of comparative exploration potential of the Gueydan and Chita-Corrigan fluvial systems. These criteria are generally applicable to evaluation of any depositional system.

1. Thick sequences rich in air fall volcanic ash should be interbedded with or should overlie potential host sands in the area of regional recharge of the host aquifer system. Increased volume or duration of ash influx increases average concentration of uranium (ppm) in recharging ground waters and increases the duration (T) of the constructional phase of mineralization.

2. Climatic extremes are unfavorable. In extremely arid climates, much dissolved uranium would be trapped in mineralized soil horizons or playas and recharge would be highly localized. Humid climates produce excess ground water that is rejected by semiconfined aquifers. Leached uranium is thus lost to the system via surface runoff. Both extremes thus decrease the efficient, uniform movement of water through surficial sediments into the aquifer system.

3. Regional host preparation by development of a reducing subsurface environment must predate the onset of the mineralization cycle. Reductants can be internally contained within the depositional system (such as detrital organic material or authigenic sulfide minerals) or can be introduced into the system post-depositionally by vertical or horizontal migration $\left(\mathrm{H}_{2} \mathrm{~S}\right.$ or other hydrocarbon gasses for example). Such regional reduction is necessary for efficient trapping (E) of dissolved uranium.

4. One or more thick, vertically integrated, highly permeable, semiconfined aquifer systems that are distributed so as to allow efficient recharge, down-gradient flow, and discharge of ground water must be present within the depositional system. Distribution of such integrated aquifers determines the volume of ground water moved through different parts of a depositional system.
Local distribution of uranium within a single depositional system is primarily a function of spatial variations in $\mathrm{Q}$. A high flux of ground water (a large $\mathrm{Q}$ ) should produce well-developed, extensive alteration tongues and associated large concentrations of uranium for the prevailing ppm, T, and $E$ in the system. Thus, within a depositional system, relative distribution and nature of ore deposits can be predicted by the application of several additional criteria.

5. In axial portions of major dip-oriented fluvial facies belts, mineralization fronts will be relatively deep, but may contain the largest individual ore bodies present in the system. At shallow subsurface positions, the axis of the facies belt will have been dominantly altered during the mineralization phase, and little mineralization will occur (fig. 30). In addition, the volume of syndepositionally oxidized channel fill, levee, and crevasse splay deposits will be significant and may obscure later alteration phenomena.

6. Along the margins of principal fluvial facies belts, numerous small- to medium-sized deposits will occur where stratigraphic or structural features enhance cross flow into or through less permeable facies (fig. 30). Good examples of such facies-margin mineralization occur at the north end of area 1 and in areas 2 and 3 (fig. 27).

7. Mineralization fronts will terminate and contain very small to small localized ore grade deposits where updip permeable elements trend subparallel to strike and thus at a high angle to the regional hydrodynamic gradient. Area 5 and the south part of area 1 on figure 27 are good examples.

8. Areas composed of numerous, isolated permeable fluvial elements within a section dominated by less permeable nonchannel facies will produce numerous, local, vertically segregated, geometrically complex mineralization fronts containing small- to medium-sized ore bodies. Size of individual ore bodies or ore trends will be proportional to the size, trend, average grain size, and degree of interconnection of the host fluvial channel fills.

9. Faulting produces facies changes, disrupts axial trends of channel-fill sands, and forms vertical flow boundaries that cause cross flow into or through less permeable facies. Geometry of mineralization fronts is affected accordingly. Concentrated flow within the permeable conduits may be dispersed (fig. 30, constructional phase) into highly reducing facies resulting in mineralization along the facies boundary or fault trend. Fault zones are likely areas for upwelling of uraniumbearing fluids into overlying permeable units forming islands of alteration within unaltered sediment. Vertical flux of ground waters also may distort the typical c-shape of the ore roll by accentuating the upper or lower wing. In extreme conditions, tabular ore bodies or areally extensive blanket mineralization may result. 


\section{COMPARATIVE EXPLORATION POTENTIAL OF GUEYDAN AND CHITA-CORRIGAN FLUVIAL SYSTEMS}

Shallow portions of the Gueydan fluvial system have been widely tested by drilling, and the abundance of deposits discovered to date proves it to be a uranium-rich system containing multiple ore bodies. Total proven reserves are unknown because reserve data are proprietary, but $10^{7}$ lbs $\mathrm{U}_{3} \mathrm{O}_{8}$ is a likely order of magnitude. Extensive exploration of intermediate to deep portions of the system can reasonably increase this figure by a factor of 10 if, as will be proposed in the following section, large ore trends occur downdip. Although ultimate reserves of the Gueydan system must remain speculative, it obviously presents a productive exploration target. In contrast, the ChitaCorrigan system has to date been explored only along its southwestern margin in Gonzales, Fayette, and Washington Counties. How does it compare with the Gueydan in terms of exploration potential? Application of the regional criteria 1 through 4 allows comparison of the reserve potential of the two fluvial systems.

1. The Chita-Corrigan fluvial system contains thick sequences of volcanic ash-derived mud and silt. Compositional trends indicate little dilution of extensive ash fall deposits by reworked older mudstone. Estimates, based on gross mineralogy, suggest that nearly 100 percent of the interchannel mud and clay was derived from alteration of ash in the Gueydan, and as much as 70 to 90 percent of the mud and clay was derived from air fall material in the Chita-Corrigan. Isopach thicknesses of the systems are comparable; thus, the Chita-Corrigan contains an ample source of uranium.

2. The strike-parallel climatic gradient evidenced by Catahoula deposits resulted in a more humid overall climate for the Chita-Corrigan system. Increasing precipitation leads to increased runoff and rejection of recharge by semiconfined aquifers. Estimates for shallow aquifers in Tyler, Washington, Montgomery, Jasper, and Newton Counties indicate about one-third to one-half of the potential recharge to the aquifers is rejected today (Tarver, 1968; Sandeen, 1972; Popkin, 1971; Wesselman, 1967). In contrast, little or no recharge is rejected by aquifers in the southern, more arid coastal plain. Uranium dissolved in gulfward-flowing surface waters is lost. The significance of recharge rejection and surface runoff would have increased northeast across the Chita-Corrigan and would have had the effect of diluting the subsurface uranium cycle. For this reason, the system wilf likely contain proportionally less trapped uranium than otherwise equivalent portions of the Gueydan system. Continued flushing by relatively dilute, less reactive waters poses the most serious limitation on the potential of the Chita-Corrigan system. However, the large volume of uranium available in the source ashes leaves room for optimism that considerable uranium entered the subsurface.
3. Much has been made of the significance of vertic ' migration of extrinsic reductants in the Gueydan fluvial system. To the extent that such vertical migration of reductants is controlled by faults, it is apparent from plate IV that the Chita-Corrigan system has not been subject to a comparably high flux of reductants at shallow to intermediate depths of burial. Local reduced chimneys may exist above piercement salt domes (reduced, pyritic muds were found at the surface above the Clay Creek dome in Washington County). Interchannel facies of the ChitaCorrigan system do contain abundant carbonaceous organic debris, pyrite balls, and other features that would produce a regionally reducing subsurface environment upon burial of the sediments below the water table. Reduced, pyritic lacustrine mudstone and claystone are common in outcrop exposures and shallow road metal pits. Relative efficiency of uranium extraction from ground waters in a system containing only intrinsic reductants might be questioned, but data comparing the width of the uranium concentration zone across mineralization fronts from various Tertiary basins (Harshman, 1974) suggest a uniformly efficient concentration process regardless of the nature or source of reductants. In addition, two types of uranium concentration not documented to date in the Gueydan system may occur in the Chita-Corrigan: (1) carbonaceous debris in crevasse and minor channel facies may produce trashpiletype deposits; and (2) lacustrine facies, which are also highly carbonaceous and sulfide rich, may form laterally extensive low-grade deposits.

4. Facies maps (plates I, II, and III) show that thick dip-oriented sand belts abound in the Chita-Corrigan fluvial system. Although average grain size of Chita-Corrigan mixed load channel-fill facies is somewhat less than that of Gueydan bedload channel deposits, average permeabilities are high and abundant crevasse splays result in wellintegrated, ground-water flow in most of the system. Volumetrically, the Chita-Corrigan system actually contains more potential host sand than the Gueydan system.

In summary, the Chita-Corrigan fluvial system has substantial potential for ore grade uranium deposits. The uranium cycle within the system likely operated less efficiently because of the more humid climatic regime, but the large volume of contained source ash, the early intrinsic reduction of potential host sediments, and the welldeveloped fluvial sand facies belts combine to form an optimistic exploration picture.

\section{EXPLORATION POTENTIAL WITHIN THE CHITA-CORRIGAN AND GUEYDAN FLUVIAL SYSTEMS}

Application of the criteria established for determination of exploration potential within a depositional system provides the basis for the map shown in figure 31 . The map 
illustrates one attempt to integrate pertinent stratigraphic, paleohydrologic, and structural data presented in this report into a single overview of exploration potential. Several important qualifications should be recognized. First, the map must compare favorability within the two systems independently. Whereas reserves of small, medium, and large deposits are quantified in the Gueydan system, based on size of some known deposits, the analogous terms are dimensionless in the Chita-Corrigan system. Actual reserve figures will depend on the overall efficiency of the uranium cycle in that system. As exploration extends into the Chita-Corrigan system, quantification of potential reserves should be possible. Obviously, early exploration efforts need to establish the comparative efficiency of the uranium cycle in the two systems. Secondly, the actual downdip extent of potential mineralization, especially in the most favorable areas, is highly speculative, although relative downdip extent within different parts of the same fluvial system can be predicted. Thus, early stages of exploration in a frontier area need to establish some downdip limits of mineralization fronts and of altered cores. These limits then provide a means of internal calibration and modification of the map. The indicated downdip extent of mineralization is supported by some drilling in the Gueydan system, but is highly speculative in the Chita-Corrigan system. Thirdly, the magnitude of deposits likely in an area is biased toward largest sizes expected. Areas with potential for medium to large deposits will also likely contain numerous small deposits. Conversely, a few large deposits may occur in stratigraphic settings that generally produce only small-or medium-sized deposits if optimal conditions occur locally. Figure 31 is an attempt to express an optimistic average for the entire Catahoula section. Fourthly, fault zones or strike-oriented facies boundaries, where cross flow is likely, are areas of particular interest within prospective parts of a system. These features are indicated on the map as an overprint on the areally defined favorability trends. Ore bodies will tend to be concentrated in the area of such facies or structural features. Finally, the extent of areas of low exploration potential can be established with much greater certainty than can the extent of favorable areas. Consequently, the map provides an optimistic view of exploration potential in that some potential has been assigned almost all areas not definitely ruled out by adverse stratigraphic relationships.

With these qualifications in mind, several specific areas enumerated on the exploration potential map (fig. 31) will be reviewed.

\section{Gueydan Fluvial System}

Area 1: The shallow, strike-parallel fluvial sand axis limited down-gradient flow of ground water and resulted in a few small deposits and numerous shows in most of Starr
County. No downdip potential exists, and shallow deposits are small.

Area 2: The thickest sands of the Gueydan fluvial system underlie Jim Hogg County. In addition, strikeparallel structural or stratigraphic features are absent in the shallow subsurface. This is an optimum area for the formation of deep mineralization fronts containing medium to large ore bodies. The lack of extensive exploration is surprising, but probably is the combined outgrowth of several factors. First, shallow deposits and shows are likely to be sparse in the axis of this broad sand complex. Drill depths along the first significant zone of faulting and stratigraphic anomalies are about $1,000 \mathrm{ft}(300 \mathrm{~m})$. Secondly, normal ground-water flow has been disrupted by Pleistocene incision of the Rio Grande, and much of Jim Hogg is now underlain by saline, relatively stagnant Catahoula waters. Rereduction of the oxidized interior of alteration tongues may have complicated interpretation of drill data, which relies on recognition of an oxidized/ reduced boundary to target further drilling. Deeper drilling in this area should produce some of the largest reserves to be found in the Catahoula Formation.

Area 3: A second area of potential deep, large deposits occurs downdip within sands of subsidiary fluvial belts in Duval County. The area is intersected by a major fault zone, and strike-oriented facies trends are common. These structural and stratigraphic elements significantly modify modern flow of ground "water (fig. 21) and provide a particularly interesting target for future exploration.

Area 4: A broad area of local fluvial sand axes and updip equivalents of area 3 extends along the outcrop and shallow subsurface from Duval County to southern Bee County. Numerous small to medium deposits are known along this belt; many others will likely be found. Prospecting should center around local fluvial channel and crevasse facies trends.

Area 5: An extensive belt of primarily strike-oriented fluvial channel sands extends across northern Live Oak, Karnes, and DeWitt Counties in the shallow subsurface. These fluvial sands interfinger basinward with the main body of the coastal lake facies (fig. 6). The general strike orientation and limited downdip extent of permeable elements portends an area much like area 1 that contains shallow, small to very small ore bodies trapped on the downdip flank of fluvial channel deposits, typically within crevasse splay sands and silts. Deep potential is lacking.

\section{Chita-Corrigan Fluvial System}

Area 6: Increasing abundance of dip-oriented fluvial channel sand axes in Lavaca, Fayette, and Colorado 


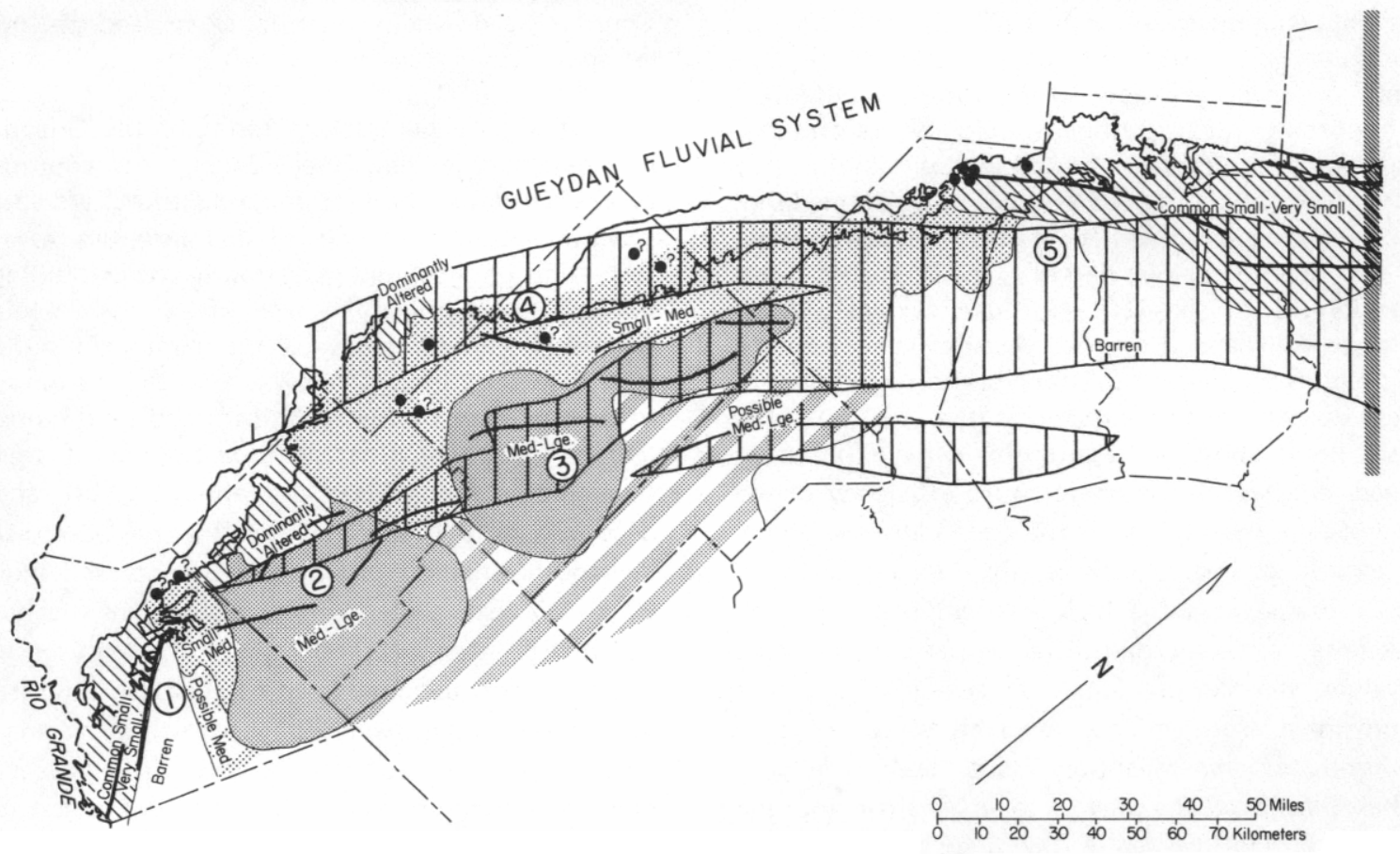

Figure 31. Summary map showing relative exploration potential within the Gueydan and Chita-Corrigan fluvial systems based on integration of stratigraphic, facies, and structural data in the context of the interpreted uranium cycle and paleo-ground-water flow system.

Counties upgrades the potential of the southern margin of the Chita-Corrigan system. Medium to small deposits are likely in the shallow to intermediate subsurface and will lie in and along the flanks of principal upper and lower Catahoula fluvial channel sand complexes. Very shallow, near-surface deposits are possible, but likely will be small. Several surface shows have been noted (plate 1). A slight possibility for a few large deposits at depth exists because the relatively coarse-grained fluvial sands in this central part of the coastal plain (fig. 19) are unusual for the ChitaCorrigan system. Faulting and vertically persistent strikeparallel facies boundaries will be of minor importance in ore localization.

Area 7: Area seven is defined by the major upper and lower Catahoula fluvial facies belt that trends downdip through Washington and Austin Counties (figs. 6 and 7). This fluvial depocenter produces a major lobe of deep fresh-water circulation now (fig. 21) and should have funneled large quantities of water deep into the subsurface during the mineralization phase. A central core of dominantly altered sands may limit medium to large ore bodies to deeper parts of the complex; however, as in the Gueydan system, medium to small deposits may also occur along the margins of the belt. Deep deposits will likely be influenced by the zone of growth faults that extends across central Austin County. Several shallow salt domes also occur within the area and could locally affect mineralization (plate IV).

Area 8: A second major fluvial belt that extends across Walker and Montgomery Counties contains as much as $400 \mathrm{ft}$ of total sand section and also has significant potential. Distribution of mineralization fronts should be similar to that of area 7; a shallow, dominantly altered core of fluvial facies will grade downdip into an extensive area containing medium to large deposits in both the upper and lower Catahoula and will be flanked by areas of potential medium to small deposits. Faults occur only in downdip parts of the area. Although the extent of potential mineralization in areas 7 and 8 (100 to 150 miles (30 to $50 \mathrm{~km}$ ) removed from the nearest mined deposits) is highly speculative, the presence of several associated surface and subsurface uranium or gamma-ray anomalies (fig. 31) shows that uranium was mobilized and concentrated within this part of the Chita-Corrigan fluvial system.

Area 9: Northeast of the Walker-Montgomery county fluvial axis, uranium exploration potential diminishes for several reasons. First, interchannel lacustrine mudstone and claystone become important facies within the system and likely acted as effective aquitards, particularly in the lower Catahoula. Thus, the flow system was more segmented, and upward discharge was retarded. Size and depth of potential ore bodies are proportionally reduced. Secondly, fluvial 


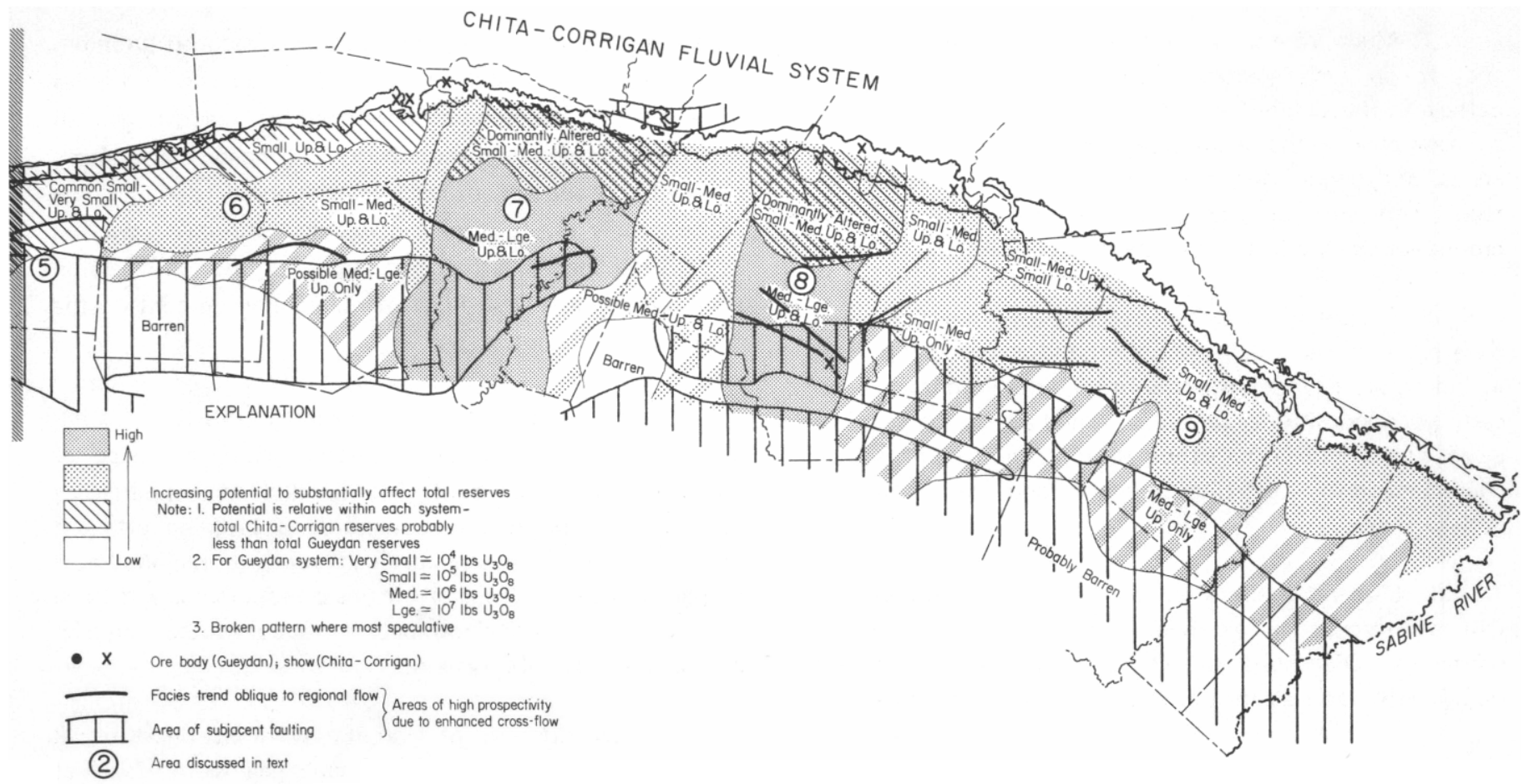

Figure 31 continued

channel facies are spread out laterally rather than stacked vertically (fig. 7), further subdividing the total flow system. Finally, the paleoclimatic gradient resulted in increasing possible loss of dissolved uranium to surface drainage from southwest to northeast across the Chita-Corrigan fluvial system. Large quantities of uranium may also have been trapped in lacustrine muds, and thus excluded from the semiconfined aquifers.

\section{CONCLUSIONS}

1. The Catahoula Formation is composed of two fluvial depositional systems. The Gueydan fluvial system was deposited in the Rio Grande embayment of South Texas and is separated from the Chita-Corrigan fluvial system, which filled the Houston embayment, by the San Marcos arch.

2. The Gueydan fluvial system consists of high bedload, channel-fill and crevasse splay facies surrounded by tuffaceous siltstone, mudstone, and claystone of floodplain and coastal lake origin. Sediment was supplied by a single large river system.

3. The Chita-Corrigan fluvial system is composed of a framework of mixed load channel-fill and associated crevasse facies surrounded by floodplain and interchannel lacustrine deposits. The system was fed by at least three major rivers and several local smaller streams.

4. Paleosoils, clay mineralogy, and other sedimentary features show that the Catahoula paleoclimate varied from relatively dry in South Texas to relatively wet in East Texas during deposition of the Catahoula Formation.

5. The sands of the Gueydan fluvial system consist of volcanic rock fragment- and plagioclase-rich feldspathic litharenite and lithic arkose; in contrast, the Chita-Corrigan sands are chert- and orthoclase-bearing subarkose, sublitharenite, lithic arenite, and feldspathic litharenite. Mud and clay in both systems were derived primarily from alteration of volcanic ash and consist of montmorillonite with accessory kaolinite in northeastern parts of the Chita-Corrigan fluvial system.

6. Reactivation of older growth fault zones by deposition of Catahoula fluvial sediments resulted in some modification of the simple gulfward-dipping structural framework. Fault zones affected sedimentary patterns by locally modifying the trend of drainage axes and have subsequently acted as hydrodynamic boundaries throughout the post-depositional history of the Catahoula aquifer. 
7. Much of the modern ground-water flow pattern and, to an even greater extent, the evolving paleoflow pattern in the Catahoula Formation is and was determined by geometry of the permeable elements, location of fault zones, and degree of vertical confinement. Consequently, facies and structural data can be used to reconstruct ground-water flow history of the two depositional systems.

8. Following deposition, sediments in the Catahoula have experienced four principal ground-water flow phases, including (1) a syndepositional or water-table phase, (2) an early post-depositional or semiconfined aquifer phase, (3) a burial phase, and (4) an exhumation phase. Each phase was characterized by differing geometry and overall flux of ground waters.

9. Diagenetic alteration of volcanic ash commenced with pedogenesis and extended through early burial of the sediments. Diagenesis of silt and fine sand-sized ash significantly reduced the permeability of crevasse units.

10. Shallow uranium mineralization fronts are concentrated along the flanks of major fluvial facies axes of the Gueydan system. Faults affect but are not a prerequisite for mineralization. Uranium fronts may lie in close proximity to the interface between oxidized and reduced sands, but also occur within hosts that are reduced and pyritic on both sides of mineralized ground.

11. The uranium cycle in the Catahoula Formation consists of a constructional phase and a modification phase. In the constructional phase, uranium was leached from ash in the zone of shallow pedogenic weathering, recharged into regional semiconfined aquifers, and concentrated along mineralization fronts that formed where geochemical gradients within the aquifer abruptly reduced uranium solubility. (The mineralization front is only one of a series of alteration phenomena developed as reactive ground water equilibrated with the subsurface geochemical environment.) In the subsequent modification phase, changing flow patterns may result in local flow stagnation and reduction of oxidized parts of alteration tongues, or outcrop recession may superimpose a surficial oxidizing environment on the mineralization front.

12. Regional factors enhancing the exploration potential of a depositional system include presence of volumetrically significant interbedded or superjacent volcanic ash, paleoclimatic conditions favoring efficient recharge of shallow semiconfined aquifers, regional host preparation by intrinsic or extrinsic reductants, and preservation of well-developed, interconnected aquifer complexes within the system.

13. Distribution of uranium within a depositional system is controlled primarily by geological factors (such as average permeability, thickness, orientation, vertical interconnection, and structural segmentation of permeable elements) that determine the relative flux of ground water through different parts of the system.

14. The Gueydan fluvial system has extensive exploration potential, particularly as depth of exploration increases. Uranium potential of the Chita-Corrigan system is also significant, but lessened because of the humid paleoclimate. Within each system, exploration potential can be assessed by integration of data on sand body geometry and trend, sedimentary facies distribution, and structural overprint in the context of the proposed uranium cycle.

\section{SPECULATIONS}

A study of this magnitude inevitably produces numerous hypotheses and suggested relationships that cannot be documented by the data at hand. Such speculations may be useful to those with additional pertinent data and provide topics for future research.

1. Disequilibrium between chemical and radiometric uranium may be related to the flux of ground water through the deposit. Certainly, stagnant flow conditions should favor equilibrium between parent and daughter isotopes. Thus, to some extent, a map such as figure 21 , that shows ground-water flux, might be useful in prediction of disequilibrium problems.

2. If, as suggested, rereduction has affected large areas of altered host sand, considerable uranium may be missed by reconnaissance exploration, which depends on recognition of oxidation fronts to guide drilling. Thus areas such as southeastern Jim Hogg County, where ground-water flux has been greatly reduced by recharge pirating, may require alternative criteria for guiding recognition of altered ground. Again, modern ground-water flow patterns defined from salinity data may be useful in predicting areas of possible rereduction.

3. The distribution of preserved organic debris below the zone of surface oxidation might be useful in defining unaltered ground. Organic debris, though generally considered to be lacking in the Catahoula Formation, is present in both depositional systems, but only in facies that have likely escaped alteration. Destruction of organic debris has been used as an indicator of alteration in Wyoming basins. 
4. Pyrite morphology may be useful for recognition of its origin. Early post-depositional pyrite that is facies related commonly forms balls or irregular masses. Disseminated pyrite or concentration within open root tubules or other cavities may be indicative of extrinsic sulfide enrichment.

5. Extensive zones of low-grade mineralization may be found in several parts of both depositional systems. Lagoonal or coastal lake facies at the transition between Catahoula fluvial and Frio deltaic/barrier facies may have syngenetically concentrated uranium moving in surface waters. Similarly, interchannel lacustrine basins may have trapped syngenetic uranium in reducing, organic-rich muds. Such zones could reach several tens of feet or meters in thickness and cover several square miles or kilometers. In addition, upward cross-stratal discharge along the downdip margin of ground-water flow systems has likely formed extensive areas of uranium enrichment along facies boundaries between permeable sands and overlying muds and silts. Gamma-ray spikes along the base of fine-grained beds above a sand unit have been noted on logs.
6. Syndepositional oxidation, especially of fluvial channel-fill, levee, and proximal crevasse deposits, may have occurred along Gueydan fluvial axes. Repeated exposure of such sediments to leaching in the phreatic zone during dry intervals and to a high flux of oxidizing, unconfined ground waters upon shallow burial may have produced thick sequences depleted in reductants. Uranium-bearing waters would later have passed through such sequences without development of mineralization fronts. Syndepositional faulting, which would have compartmentalized the shallow, unconfined aquifers and thus retarded flow as well as provided a possible source for extrinsic reductants, may have been necessary for development and preservation of a reducing subsurface environment in updip portions of the Gueydan fluvial system.

7. Facies analysis may help explain or predict permeability anisotropy of host sands at proposed in situ leach mining operations. Crevasse and channel-fill units likely will have differing directions of highest permeability. In addition, clay dikes may partition the host and require modification of well field patterns.

\section{ACKNOWLEDGEMENTS}

Numerous persons aided in the completion of this report and their time and interest are gratefully acknowledged. L. F. Brown, Jr., and J. H. McGowen critically reviewed the manuscript and discussed various aspects of the study. Mike Lane (Chevron), James Knupke (Independent Geologist), Thomas Henderson, Jr. (Independent Geologist), and numerous other individuals aided in acquisition of cores, logs, and samples used in the study. Special thanks go to Lonney Tracey (Conquista Project) and to Continental Oil Company for permission to study and sample active uranium mines, and to Geomap Company for use of structure map folios. L. J. Turk and C.W. Kreitler discussed hydrologic aspects and contributed useful ideas and criticism. Figures and plates were drafted under the supervision of J.W. Macon. Research assistants, T. D. Murphy, R. C. Belcher, B. D. Johnson, and Stanley Sutton contributed significantly; their energy and enthusiasm are particularly appreciated.

\section{REFERENCES}

Adams, J.A.S., 1954, Uranium and thorium contents of volcanic rocks, in Faul, $\mathrm{H}$., ed., Nuclear geology: New York, John Wiley and Sons, Inc., p. 89-98.

Bailey, T. L., 1926, The Gueydan, a new middle Tertiary formation from the southwestern coastal plain of Texas: University of Texas Bull. no. 2645, 187 p.

Barnes, V. E., proj. director, 1968, Beaumont sheet: Univ. Texas, Austin, Bur. Econ. Geology Geol. Atlas of Texas, scale 1:250,000.

1968, Palestine sheet: Univ. Texas, Austin, Bur. Econ. Geology Geol. Atlas of Texas, scale 1:250,000. 1974, Austin sheet: Univ. Texas, Austin, Bur. Econ. Geology Geol. Atlas of Texas, scale 1:250,000. 1974, Seguin sheet: Univ. Texas, Austin, Bur. Econ. Geology Geol. Atlas of Texas, scale 1:250,000. 1975, Beeville-Bay City sheet: Univ. Texas, Austin, Bur. Econ. Geology Geol. Atlas of Texas, scale $1: 250,000$.
1976, Crystal City-Eagle Pass sheet: Univ. Texas, Austin, Bur. Econ. Geology Geol. Atlas of Texas, scale $1: 250,000$.

Bebout, D. G., Agagu, O. K., and Dorfman, M. H., 1975a, Geothermal resources, Frio Formation, Middle Texas Gulf Coast: Univ. Texas, Austin, Bur. Econ. Geology Geol. Circ. 75-8, 43 p.

Dorfman, M. H., and Agagu, O. K., 1975b, Geothermal resources, Frio Formation, south Texas: Univ. Texas, Austin, Bur. Econ. Geology Geol. Circ. 75-1, 36 p.

, Loucks, R. G., Bosch, S. C., and Dorfman, M. H., 1976, Geothermal resources, Frio Formation, Upper Texas Gulf Coast: Univ. Texas, Austin, Bur. Econ. Geology Geol. Circ. 76-3, 47 p.

Belcher, R. C., 1975, The geomorphic evolution of the Rio Grande: Baylor Geological Studies Bull. no. 29,64 p.

Bernard, H. A., Major, C. F., Jr., Parrott, B. S., and LeBlanc, R. J., Sr., 1970, Recent sediments of south- 
east Texas: Univ. Texas, Austin, Bur. Econ. Geology Guidebook no. 11, 120 p. plus appendix.

Bluck, B. J., 1971, Sedimentation in the meandering River Endrick: Scottish Jour. of Geology, v. 7, pt. 2, p. 93-138.

Brewer, R., 1964, Fabric and mineral analysis of soils: New York, John Wiley and Sons, Inc., $470 \mathrm{p}$.

Brown, L. F., Jr., Cleaves, A. W., II, and Erxleben, A.W., 1973, Pennsylvanian depositional systems in NorthCentral Texas: Univ. Texas, Austin, Bur. Econ. Geology Guidebook no. 14, 122 p.

Bruce, C. H., 1972, Pressured shale and related sediment deformation: A mechanism for development of regional contemporaneous faults: Gulf Coast Assoc. Geol. Socs. Trans., v. 22, p. 23-31.

Bunker, C. M., and MacKallor, J. A., 1973, Geology of the oxidized uranium ore deposits of the Tordilla HillDeweesville area, Karnes County, Texas; a study of a district before mining: U. S. Geol. Survey Prof. Paper 765, $37 \mathrm{p}$.

Butler, A. P., Jr., 1969, Groundwater as related to the origin and search for uranium deposits in sandstones: Contr. to Geology, v. 8, no. 2, pt. 1, p. 81-86.

Carver, R. E., 1968, Differential compaction as a cause of regional contemporaneous faults: Am. Assoc. Petroleum Geologists Bull., v. 52, no. 3, p. 414-419.

Chorley, R. J., and Kennedy, B. A., 1971, Physical geography, a systems approach: London, Prentice-Hall Internatl., $370 \mathrm{p}$.

Coleman, J. M., 1966, Ecological changes in a massive fresh-water clay sequence: Gulf Coast Assoc. Geol. Socs. Trans., v. 16, p. 159-174.

1969, Brahmaputra river: Channel processes and sedimentation: Sed. Geology, v. 3, p. 129-239.

Dailly, G. C., 1976, A possible mechanism relating progradation, growth faulting, clay diapirism and overthrusting in a regressive sequence of sediments: Bull. of Canadian Petroleum Geology, v. 24, no. 1, p. $92-116$.

Davies, D. K., 1976, Continental volcanic sediments and their sedimentation: Am. Assoc. Petroleum Geologists Bull., v. 60,662 p.

Deussen, A., and Owen, K. D., 1939, Correlation of surface and subsurface formations in two typical sections of the Gulf Coast of Texas: Am. Assoc. Petroleum Geologists Bull., v. 23, p. 1603-1634.

Doi, K., Hirono, S., and Sakamaki, Y., 1975, Uranium mineralization by ground water in sedimentary rocks, Japan: Econ. Geology, v. 70, p. 628-646.

Duex, T. W., 1971, K/Ar dates and U, K geochemistry of Gueydan (Catahoula) Formation, in Adams, J.A.S., ed., Final Report U.S.A.E.C. Research Contract AT (05-1)-935, pt. 7, p. 101-145.

Dumble, E. T., 1918, The geology of east Texas: Univ. Texas Bull. no. 1869, 325 p.

Eargle, D. H., Dickinson, K. A., and Davis, B. O., 1975, South Texas uranium deposits: Am. Assoc. Petroleum Geologists, v. 59 , no. 5 , p. $766-779$.
, Hinds, G. W., and Weeks, A.M.D., 1971, Uranium geology and mines, south Texas: Univ. Texas, Austin, Bur. Econ. Geology Guidebook no. 12, 59 p.

, and Weeks, A.M.D., 1961, Possible relation between hydrogen sulfide-bearing hydrocarbons in fault-line oil fields and uranium deposits in the southeast Texas coastal plain: U.S. Geol. Survey Prof. Paper 424-D, p. 7-9.

, and Weeks, A.M.D., 1968, Factors in the formation of uranium deposits, coastal plain of Texas: South Texas Geol. Soc. Bull. 9, no. 3, p. 3-13.

, and Weeks, A.M.D., 1973, Geologic relations among uranium deposits, South Texas coastal plain region, U.S.A., in Amstutz, G. C., and Bernard, A. J., eds., Ores in sediments: Internatl. Union Geol. Sci., p. 101-113.

Energy Research and Development Administration (E.R.D.A.), 1975, Gamma radiation spectral survey of the Jackson/Goliad Formations in Texas: U.S.A.E.C. Contract No. AT (05-1)-1632.

Fischer, R. P., 1974, Exploration guides to new uranium districts and belts: Econ. Geology, v. 69, no. 3, p. 362-376.

Fisher, W. L., 1965, Rock and mineral resources of East Texas: Univ. Texas, Austin, Bur. Econ. Geology Rept. Inv. no. 54, 439 p. 1969, Facies characterization of Gulf Coast basin delta systems, with some Holocene analogues: Gulf Coast Assoc. Geol. Socs. Trans., v. 19, p. 239-261. 1973, Deltaic sedimentation, salt mobilization and growth faulting in Gulf Coast basin: Am. Assoc. Petroleum Geologists, Abs., v. 57, no. 4, p. 779.

, Brown, L. F., Jr., Scott, A. J., and McGowen, J. H., 1969, Delta systems in the exploration for oil and gas: Univ. Texas, Austin, Bur. Econ. Geology, Research Colloquium, $212 \mathrm{p}$.

, and McGowen, J. H., 1967, Depositional systems in the Wilcox Group of Texas and their relationship to occurrence of oil and gas: Am. Assoc. Petroleum Geologists Bull., v. 53, p. 30-54.

, Proctor, C. V., Jr., Galloway, W. E., and Nagle, J.S., 1970, Depositional systems in the Jackson Group of Texas-Their relationship to oil, gas, and uranium: Univ. Texas, Austin, Bur. Econ. Geology Geol. Circ. 70-4, 27 p. Reprinted from Gulf Coast Assoc. Geol. Socs. Trans, v. 20, p. 234-261.

Fisk, H. N., 1952, Geological investigations of the Atchafalaya basin and the problem of Mississippi river diversion-v. 1: Vicksburg, Miss., U. S. Army Corps Engineers, Waterways Expt. Sta., 145 p.

Fitz Patrick, E. A., 1971, Pedology: Edinburgh, Oliver and Boyd, $306 \mathrm{p}$.

Folk, R. L., 1974, Petrology of sedimentary rocks: Austin, Hemphill Publishing Co., 182 p.

Freeman, P. S., 1968, Exposed middle Tertiary mud diapirs and related features in south Texas, in Braunstein, J., and O'Brien, G. D., eds., Diapirism and diapirs: Tulsa, Oklahoma, Am. Assoc. Petroleum Geologists, p. $162 \cdot 182$. 
Freeze, R. A., 1969a, The mechanism of natural groundwater recharge and discharge. 1. One-dimensional, vertical, unsteady, unsaturated flow above a recharging or discharging ground-water flow system: Water Resources Research, v. 5, no. 1, p. 153-170. $1969 \mathrm{~b}$, Theoretical analysis of regional groundwater flow: Dept. Energy, Mines and Resources, Canada Inland Waters Branch, Ottawa Scientific Ser., no. 3, $147 \mathrm{p}$.

Gottfried, D., Moore, R., and Caemmerer, A., 1962 , Thorium and uranium in some alkalic igneous rocks from Virginia and Texas: Geol. Survey Research 1962, article 27, p. B70-B72.

Grutt, E. W., Jr., 1971, Prospecting criteria for sandstonetype uranium deposits, in Methods of prospecting for uranium minerals: N.A.T.O., p. 47-78.

Guevara, E. H., and Garcia, R., 1972, Depositional systems and oil-gas reservoirs in the Queen City Formation of Texas: Univ. Texas, Austin, Bur. Econ. Geology Geol. Circ. 72-4, 22 p. Reprinted from Gulf Coast Assoc. Geol. Socs. Trans., v. 22, p. 1-22.

Gustavson, T. C., 1975, Microrelief (gilgai) structures on expansive clays of the Texas Coastal Plain-Their recognition and significance in engineering construction: Univ. Texas, Austin, Bur. Econ. Geology Geol. Circ. 75-7, $18 \mathrm{p}$.

Hagmaier, J. L., 1971, The relation of uranium occurrences to groundwater flow systems: Wyoming Geol. Assoc., Earth Sci. Bull., v. 4, p. 19-24.

Hardin, G. C., 1962, Notes on Cenozoic sedimentation in the Gulf Coast geosyncline, U.S.A., in Rainwater, E. H., and Zingula, R.P., eds., Geology of the Gulf Coast and Central Texas: Houston Geol. Soc., p. 1-15.

Harshman, E. N., 1974, Distribution of elements in some roll-type uranium deposits, in Formation of uranium ore deposits: Vienna, Atomic Energy Agency, Proc., p. 169-183.

Hay, R. L., 1959, Origin and weathering of late Pleistocene ash deposits on St. Vincent, BWI: Jour. Geology, v. 67, p. 65-87.

Hostetler, P. B., and Garrels, R. M., 1962, Transportation and precipitation of uranium and vanadium at low temperatures, with special reference to sandstone type uranium deposits: Econ. Geology, v. 57, no. 2. p. 137-163.

Houston Geological Society, 1954, Stratigraphy of the upper Gulf Coast of Texas and strike and dip sections-upper Gulf Coast of Texas: Houston Geol. Soc. Study Group Rept. 1953-1954, 25 p.

Jackson, R. G., II, 1976, Depositional model of point bars in the lower Wabash river: Jour. Sed. Petrology, v. 46, no. 3, p. 579-594.

Jones, P. H., 1968, Hydrology of Neogene deposits in northern Gulf of Mexico basin: U.S. Geol. Survey Open File Rept., 110 p.

___ , and Wallace, R. H., Jr., 1974, Hydrogeologic aspects of structural deformation in the northern
Gulf of Mexico basin: U.S. Geol. Survey, Jour. Research, v. 2, no. 5, p. 511-517.

Klohn, M. L., and Pickens, W. R., 1970, Geology of the Felder uranium deposits, Live Oak County, Texas: Mining Engineers Soc. Reprint no. 70-1-38, 19 p.; paper presented at AIME Ann. Mtg., Denver, Colorado, Feb. 15-19, 1970.

Kreitler, C. W., 1976, Lineations and faults in the Texas Coastal Zone: Univ. Texas, Austin, Bur. Econ. Geology Rept. Inv. no. 85, 32 p.

Masch, F. D., and Denny, K. J., 1966, Grain size distribution and its effect on the permeability of unconsolidated sands: Water Resources Research, v. 2, p. 665-677.

McBride, E. F., Lindemann, W. L., and Freeman, P. S., 1968, Lithology and petrology of the Gueydan (Catahoula) Formation in South Texas: Univ. Texas, Austin, Bur. Econ. Geology Rept. Inv. no. 63, 122 p.

McCracken, W. A., 1967, Petrology of the Catahoula Formation (Miocene) in northeastern Gonzales County, northwestern Lavaca County, and southwestern Fayette County, Texas: Univ. Houston, Master's thesis, $127 \mathrm{p}$.

McGannon, D. E., Jr., 1975, Primary fluvial oolites: Jour. Sed. Petrology, v. 45, p. 719-727.

McGowen, J. H., and Garner, L. E., 1970, Physiographic features and stratification types of coarse-grained point bars: modern and ancient examples: Sedimentology, v. 14, p. 77-111. Reprinted as Univ. Texas, Austin, Bur. Econ. Geology Geol. Circ. 75-9, 27 p., 1975.

McKnight, W. M., Jr., 1972, A review of South Texas uranium geology: Gulf Coast Assoc. Geol. Socs. Trans., v. 22, p. 97-103.

Moxham, R. M., 1964, Radioelement dispersion in a sedimentary environment and its effect on uranium exploration: Econ. Geology, v. 59, no. 2, p. 309-321.

Murray, G. E., 1960, Geologic framework of Gulf coastal province of United States, in Shepard, F. P., Phleger, F. B., and van Andel, T. H., eds., Recent sediments, northwest Gulf of Mexico: Tulsa, Oklahoma, Am. Assoc. Petroleum Geologists, p. 15-35.

Payne, J. N., 1968, Hydrologic significance of the lithofacies of the Sparta sand in Arkansas, Louisiana, Mississippi and Texas: U. S. Geol. Survey Prof. Paper 569-A, 17 p.

1975, Geohydrologic significance of lithofacies of the Carrizo sand of Arkansas, Louisiana, and Texas and the Meridan sand of Mississippi: U.S. Geol. Survey Prof. Paper 569-D, 11 p.

Popkin, B. P., 1971, Ground-water resources of Montgomery County, Texas: Texas Water Development Board Rept. 136, 131 p.

Reineck, H. E., and Singh, I. B., 1975, Depositional sedimentary environments: New York, SpringerVerlag, $439 \mathrm{p}$.

Renick, B. C., 1936, The Jackson Group and the Catahoula and Oakville Formation in a part of the Texas Gulf Coastal Plain: Univ. Texas Bull. no. 2645, 187 p. 
Sandeen, W. M., 1972, Ground-water resources of Washington County, Texas: Texas Water Development Board Rept. 162, 105 p.

Schumm, S. A., 1960, The effect of sediment type on the shape and stratification of some modern fluvial deposits: Am. Jour. Science, v. 258, p. 177-184.

1968a, Speculations concerning paleohydrologic controls of terrestrial sedimentation: Geol. Soc. America Bull., v. 79, p. 1573-1588.

$1968 \mathrm{~b}$, River adjustment to altered hydrologic regime-Murrumbidgee River and paleochannels, Australia: U.S. Geol. Survey Prof. Paper 598, 65 p.

1972, Fluvial paleochannels, in Rigby, J. K., and Hamblin, W. K., eds., Recognition of ancient sedimentary environments: Tusla, Oklahoma, Soc. Econ. Paleontologists and Mineralogists Spec. Pub. no. 19, p. 98-107.

Shell Oil Company, 1975, Stratigraphic Atlas of North and Central America: Houston, Texas, Shell Oil Co.

Skibitzke, H. E., and Robinson, G. M., 1963, Dispersion in ground water flowing through heterogeneous materials: U.S. Geol. Survey Prof. Paper 386-B, p. B1-B3.

Tarver, G. R., 1968, Ground-water resources of Tyler County, Texas: Texas Water Development Board Rept. 74, 91 p.

Taylor, P. S., and Stoiber, R. E., 1973, Soluble material on ash from active Central American volcanoes: Geol. Soc. America Bull., v. 84, p. 1031-1042.

Thomas, G. L., 1960, Petrography of the Catahoula Formation in Texas: Univ. Texas [Austin], Master's thesis, $88 \mathrm{p}$.

Toth, J., 1962, A theory of groundwater motion in small drainage basins in central Alberta, Canada: Jour. Geophys. Research, v. 67, no. 11, p. 4375-4387.

Tucker, D. R., 1967, Faults of South and Central Texas: Gulf Coast Assoc. Geol. Socs. Trans., v. 17, p. 144-147.

Walton, A. W., 1968, Clay mineralogy of the upper part of the Jackson Group and the Catahoula Formation, east-central Texas: Univ. Texas, Austin, Master's thesis, $117 \mathrm{p}$.

1975, Zeolitic diagenesis in Oligocene volcanic sediments, Trans-Pecos Texas: Geol. Soc. America Bull., v. 86, p. 615-624.

Weeks, A.M.D., and Eargle, D. H., 1963, Relation of diagenetic alteration and soil-forming processes to the uranium deposits of the southeast Texas coastal plain: Clays and Clay Minerals, v. 10, p. 23-41.

Wesselman, J. B., 1967, Ground-water resources of Jasper and Newton Counties, Texas: Texas Water Development Board Rept. 59, 167 p.

Wilcox, R. E., 1959, Some effects of recent volcanic ash falls with special reference to Alaska: U.S. Geol. Survey Bull. 1028-N, p. 409-476. 
APPENDIX 


\section{APPENDIX 1}

Well Logs Used in Cross Sections D-D', and $0-0^{\prime}$ (figures 4 and 5 ).

\section{Section D-D' \\ County}

Webb

Duval

Section $0.0^{\prime}$

Walker

Montgomery
"Q" Number

Q-251

Q-535

Q-1412

Q-1573

Q-75

Q-572

Q-585

Q-746

Q-1085

Q-660

Q-490

Q-23

Q-44

Q-35

Q.7

Q-45

Q-11

Q-36

Q-276

Q-237

Q-252

Q-283

Q-228

Q-229

Q-43

Q.174

0-335

0-246
Operator

San Antonio Oil Refinery Corp.

Humble Oil \& Refining Co.

M.J. Coffey Co.

Standard Oil Co. of Texas

The Texas Co.

Continental Oil Co.

Continental Oil Co.

Continental Oil Co.

M.M. Miller \& Sons

F. William Carr Co.

Morgan Mineral Corp.

City of Huntsville

Hinkle Drilling Co.

J.O. Ehlinger

Morris K. Womack

William G. Murray

Garrett et al.

Moran Oil Corp.

Moran Oil Corp. \&

Garfield Oil Co.

Anderson \& Prichard

L.M. York

Kirby Petroleum Co.

Morris K. Womack

Kobbe \& Spear

J. Newton Hozor

G.W. Strake

Paul Sanderson

Humble Oil \& Refining Co.
Fee

Floyd Billings No. 1

V. Kohler \# A-86

Gruy Estate \# 1

Gruy Estate \# 4

D.C. Chapa (NCT-1)

Well \# 6

Clara Driscoll

S-51-2

Robert Driscoll \# 115

Driscoll \# B-5

Miller Fee \# 24

\# 1 M.M. Miller

Rodriguez \# 1

No. 8

J.S. Angier \# 1

Foster Estate \# 1

T.S. Foster Est. \# 1

Central Coal \& Coke \# 1

Bellinocuski \# 1

Hardy \# 2

Mclntry \# 1

Spiller \# 1

Trust Co. \#1

Skaly \# 1

Hutchines, Sealy Nat.

Bank Trustee \# 1

Yovens \# 1

Brent \# 1

Krohn B \# 1.W

Wildcat Splendoran \# 1

May Qualline No. 1 


\title{
APPENDIX 2
}

\author{
Localities Illustrated in Facies Cross Sections \\ (figures 10 and 12).
}

Figure 10

A. Locality 6/1-6: Road metal pits at intersection of unmarked county roads 2 miles west of intersection of U. S. 281 and S. H. 9, Live Oak County. Distal crevasse splay and crevasse channel facies at base of Catahoula. Approximately 14 feet of section well exposed.

B. Conquista Project uranium mine: Three miles north-northeast of intersection of U. S. 281 and R. M. 2049 , Live Oak County. Open pit exposed 150 feet of section consisting of tuffaceous proximal crevasse and interbedded crevasse delta and coastal lake facies in basal Catahoula. (Also shown in figure 9.)

C. Conquista Project uranium mine: Two miles west of Hobson community, Karnes County. Open pit exposure of very sandy proximal crevasse splay channel fills in base of Catahoula.

D. Cores from uranium prospect, southeast Webb County: Proximal crevasse facies deposited very close to major channel axis.

E. Conquista Project Rosenbrock uranium mine: Northwest of Coy City community 2.5 miles, Karnes County. Open pit exposure of bedload channel-fiff unit 65 feet thick. (Also shown in figure 8 .)

\section{Figure 12}

A. Locality 6/9-2: Small road metal pit and road cuts, 0.8 mile southeast on FAS 1007 from intersection with U. S. 96, Jasper County. Well-developed pedogenic features in distal crevasse facies.

B. Locality 6/8-5: Cuts along overflow channel of Sam Rayburn Reservoir, south edge of Ebenezer-Letney Parks, Jasper County. Interbedded sequence of distal crevasse and crevasse delta, floodplain, and lacustrine deposits. Fifteen feet of section well exposed.

C. Locality 5/17-3: Main Milwhite clay pit, south of FAS 980, on northwest edge of Riverside, Walker County. Approximately 70 feet of lacustrine and proximal crevasse delta facies exposed. Adjoining pits contain highly siliceous lacustrine mudstone and paleosoils.

D. Locality 5/17-4: Road cut, south end of S. H. 19 bridge over Trinity River, Walker County. Proximal crevasse channel overlying coarsening-upward distal crevasse deposits.

E. Locality 4/28-2: Creek bank, road cuts and road metal pit exposures along FAS 244, one mile northwest of intersection with FAS 90 (near Anderson), Grimes County. Composite 30-foot section of fluvial channel fill.

F. Locality 6/8-6: Wave-cut cliff along bank of Sam Rayburn Reservoir, Ebenezer-Letney park swimming area, Jasper County. Channel-fill sand facies showing crude fining-up sequence and internal reactivation surfaces. Total section approximatley 45 feet thick.

G. Locality 5/18-6: Abandoned sand pit south of FAS 352 in Stryker Community. Polk County. Upper 30 feet of a thick fining-upward channel-fill sand unit exposed in pit walls; estimated 20 to 30 feet of additional sand below water level. 



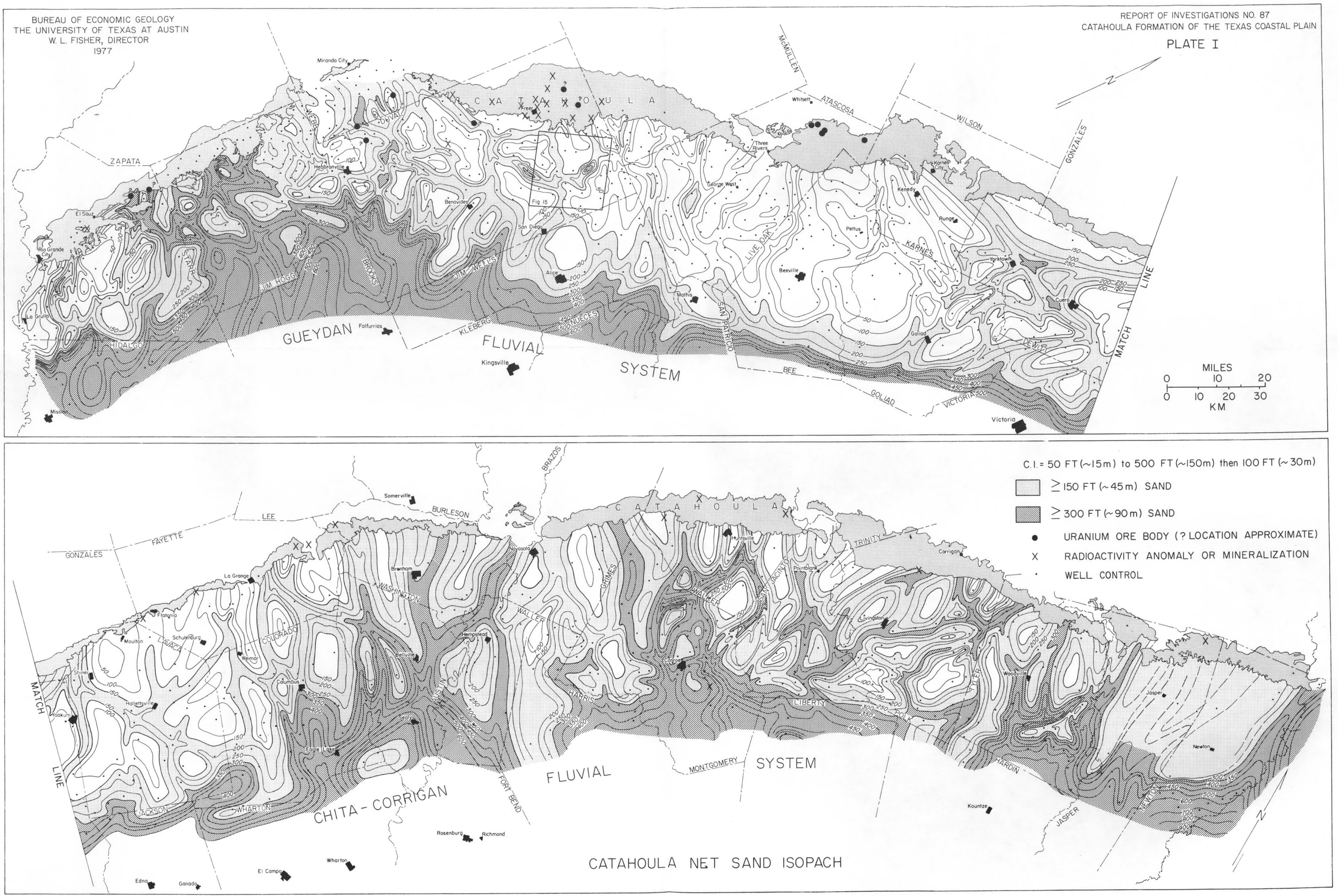




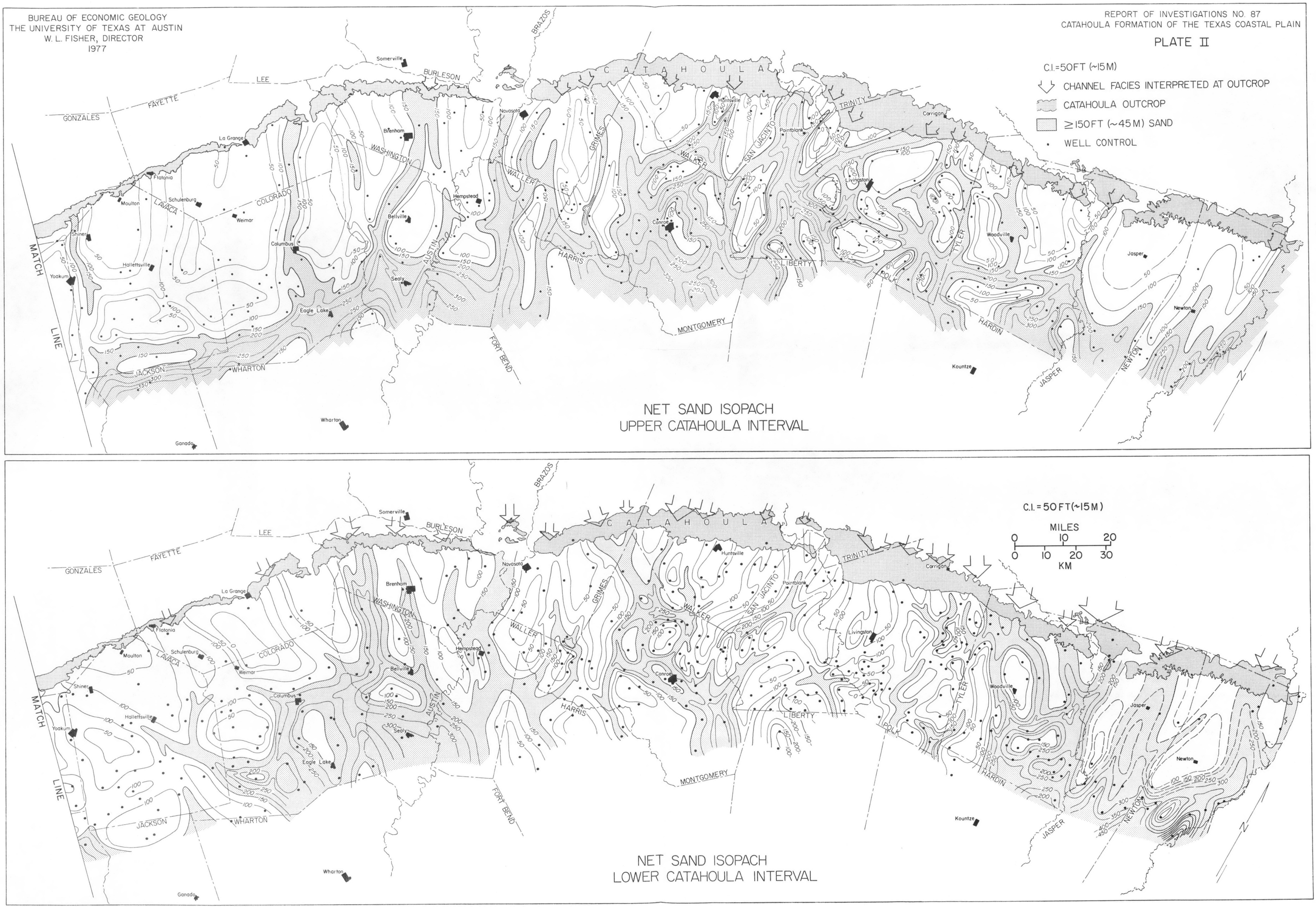



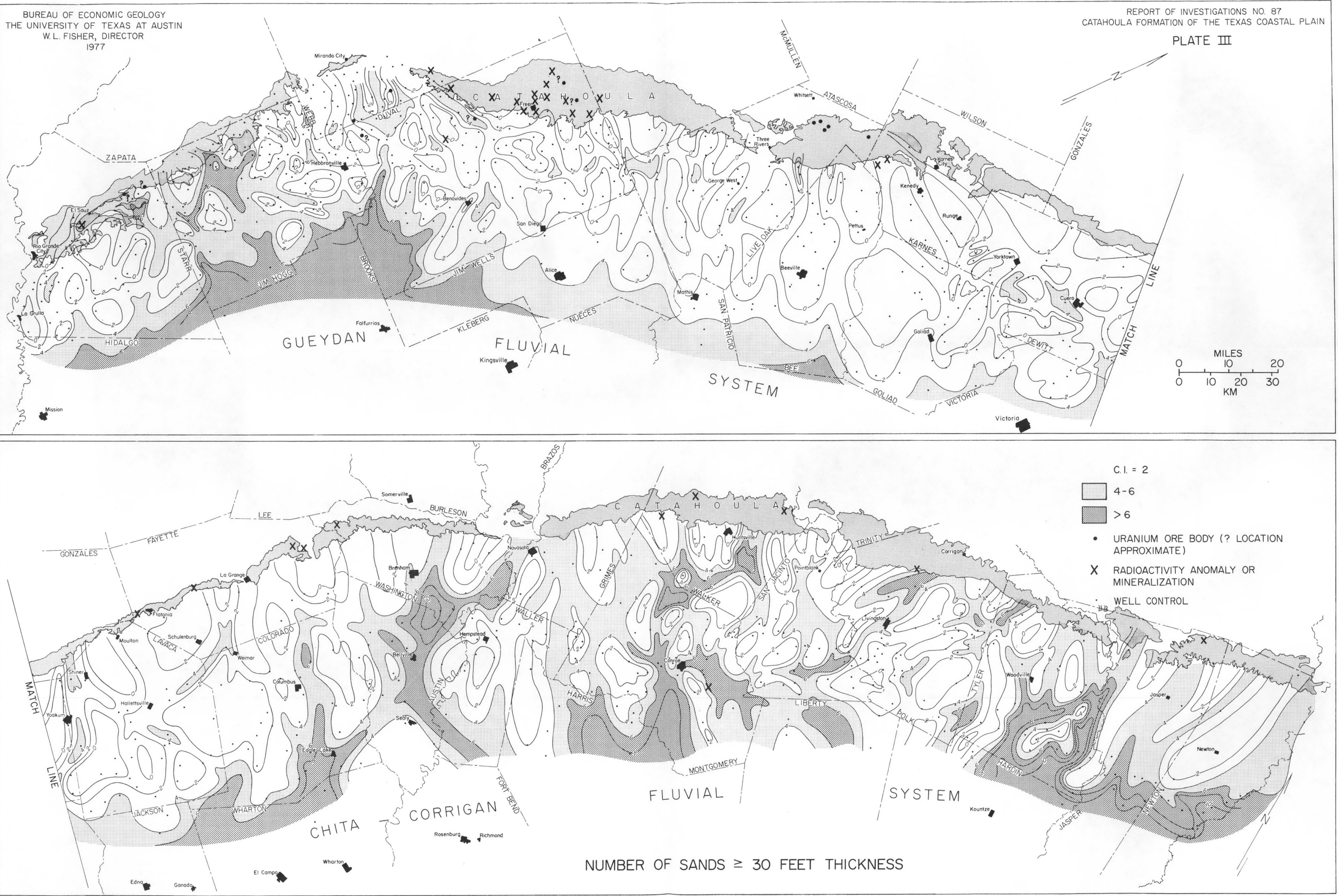





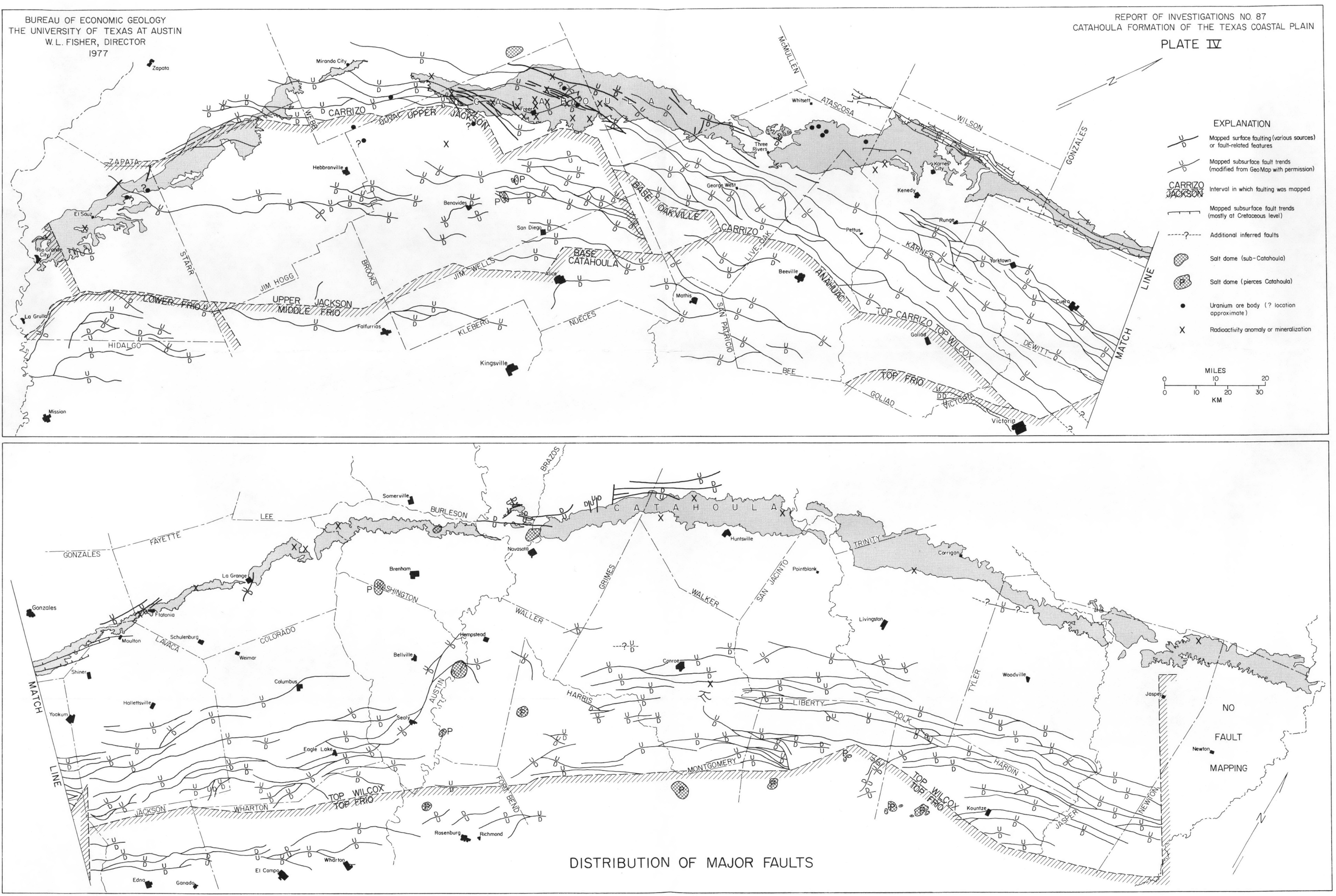


